This PDF (landscape to accommodate the table data) is a simplified version of the original article published in Internet Archaeology. All links and images connect back to the original version online.

Please cite this as: Wood J. R., Hsu, Y-T and Bell, C. 2021 Sending Laurion Back to the Future: Bronze Age Silver and the Source of Confusion, Internet Archaeology 56. https://doi.org/10.11141/ia.56.9

\title{
Sending Laurion Back to the Future: Bronze Age Silver and the Source of Confusion
}

Jonathan R. Wood, Yi-Ting Hsu and Carol Bell

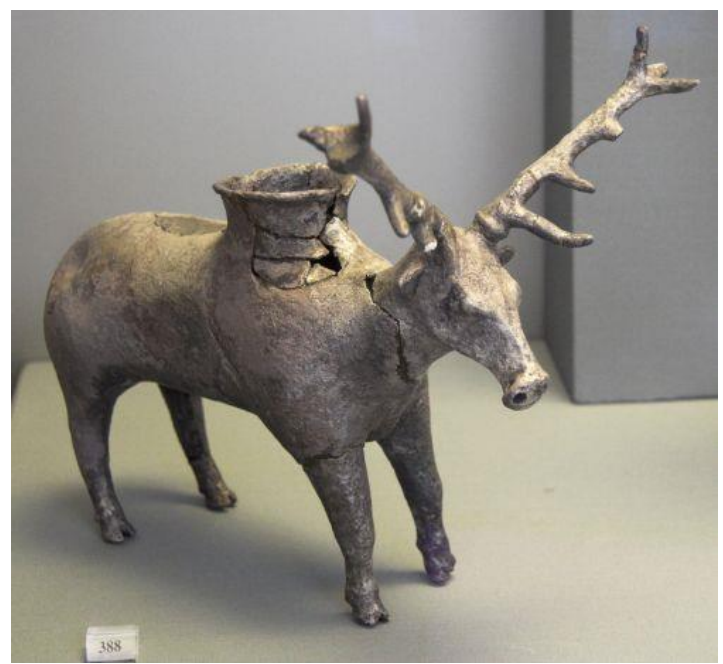

Silver stag rhyton (SG388) from Mycenae in the National Museum of Athens (NMA388). Photo by Zde (CC-BY-SA-3.0)

Silver-bearing lead ores at Laurion in Attica were considered to have been first exploited with the introduction of coinage sometime around the birth of Classical Greece. However, in the late 20th century this chronology was radically revised earlier, to the Bronze Age, largely supported by lead isotope analyses (LIA). Here, we acknowledge that lead and silver metallurgy emerged from the earliest times 
but we propose that any correlation between these metals in the archaeological record is not a consequence of a geological association between lead and silver in ores such as galena until the middle of the first millennium BCE. We suggest that ancient metallurgists recognised that silver minerals (such as horn silver) dispersed in host rocks could be concentrated in molten lead and that LIA signatures of Bronze Age silver artefacts reflect the use of exogenous lead to extract silver, perhaps applying processes similar to those used to acquire silver in Bronze Age Siphnos. We further propose that lead from Laurion used for silver extraction resulted in the inadvertent transfer of its LIA signature (probably aided by roving silver prospectors) to silver objects and metallurgical debris recovered around the Aegean. New compositional analyses for the Mycenaean shaft-grave silver (c. 1600 BCE) support these conclusions. We believe that reverting to the mid-first millennium BCE for the first exploitation of silver from argentiferous lead ores is consistent with the absence of archaeological evidence for centralised control over Laurion until the Archaic period, the paucity of lead slag associated with silver-

processing debris at Bronze Age sites, the scarcity of silver artefacts recovered in post-shaft grave contexts at Mycenae and throughout the Early Iron Age Aegean, the few Attic silver coins with LIA signatures consistent with Laurion until after 500 BCE and a single unambiguous mention of silver in the Linear B texts.

\section{Lead, Silver and Processing Debris}

There is no doubt that vast quantities of lead were mined around the Mediterranean during the first millennium BCE. Ancient slag heaps and processing installations, such as those at Laurion in Greece (e.g. Hopper 1968; Healy 1978; Ellis Jones 1982), finds of lead objects, as well as emission data from ice-cores in Greenland (e.g. McConnell et al. 2018), demonstrate that lead ores were mined and smelted during the Iron Age. Furthermore, lead artefacts and debris associated with smelting lead ores (e.g. slag) are found in Bronze Age contexts in the Near East (e.g. Yener et al. 1991; Hess et al. 1998; Pernicka et al. 1998; Hauptmann et al. 2002; Efe and Fidan 2006) and around the Aegean (e.g. Gale and Stos-Gale 1981a). In fact, the relative ease of reducing lead ores to lead suggests that lead may have been the first metal to be smelted, probably in the Near East or Anatolia and perhaps as early as the seventh millennium BCE (Gale and Stos-Gale 1981b), or at least as early as the late fifth millennium BCE in the Levant (Yahalom-Mack et al. 2015).

In some instances, lead ores were mined solely for lead (e.g. Pliny, writing in the 1st century CE, mentions its use for pipes and sheet - NH xxxiv, 159). In other instances, lead was exploited in order to extract the trace amounts of silver that reside in argentiferous lead ores. Childe (1936) argues that lead ores were probably at first valued for the silver they contain, but this could only have been the case if the lead had already been found to contain silver (Forbes 1950,173 ). Where silver is associated with the lead ores, such as in argentiferous galena $(\mathrm{PbS})$ and cerussite $\left(\mathrm{PbCO}_{3}\right)$, the ores are smelted, with the silver being collected by the intrinsic lead metal produced during smelting. For argentiferous ores with insufficient lead (such as the jarosites of south-west lberia), lead must be added 
during the smelt (Anguilano et al. 2009; Murillo-Barroso et al. 2016; Wood et al. 2019; Wood and Montero-Ruiz 2019). In both cases, however, the argentiferous lead metal produced needs to be cupellated (Figure 1) in order to retrieve the silver that partitions into it during smelting (Craddock 1995, 205-33; L'Heritier et al. 2015; Moureau and Thomas 2016). Evidence for the cupellation process is therefore indicative of silver production, regardless of which types of argentiferous ores are smelted, whereas evidence of smelting lead ores could be a consequence of lead and/or silver production.
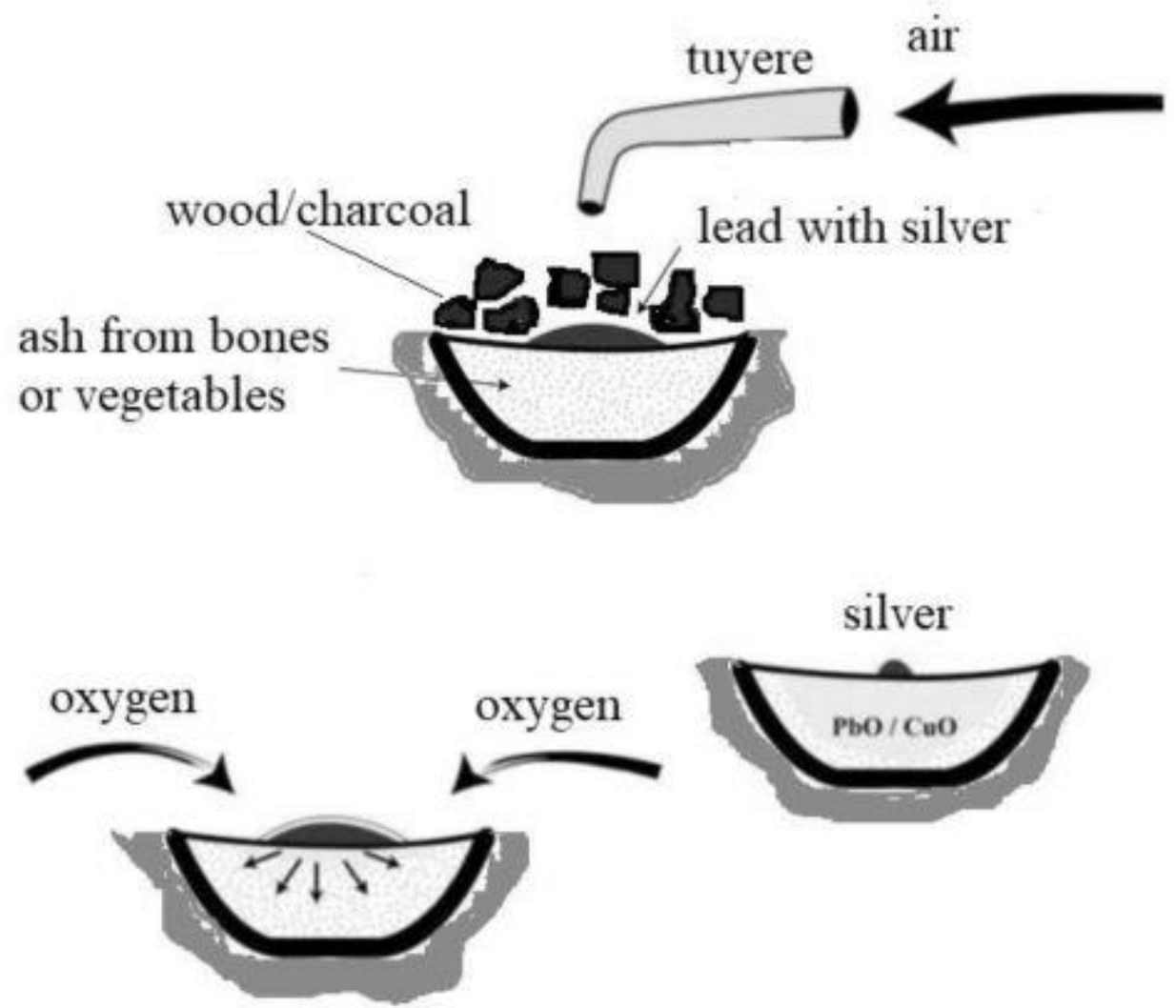

Figure 1: Schematic of the cupellation process. Argentiferous lead, derived from either smelting argentiferous lead ores (such as cerussite or galena), or by smelting an argentiferous ore (such as jarosite) with exogenous lead, is oxidised under a stream of air at a temperature of about $1000^{\circ} \mathrm{C}$. The molten litharge can be absorbed (possibly by bone ash), along with any other metal impurities that 
oxidise (e.g. copper), leaving the silver and any inert impurities (such as gold) as a separate phase (adapted from Moureau and Thomas $\underline{2016}$ )

Cupellation produces litharge $(\mathrm{PbO})$ as lead metal is oxidised in order to separate the less reactive silver from the argentiferous lead produced from smelting argentiferous ores. Extracting silver from argentiferous lead in ancient times required oxidising the lead to litharge by heating the molten lead to temperatures of about $1000^{\circ} \mathrm{C}$ under a stream of air (Craddock 1995, 205-33; L'Heritier et al. 2015). With a melting point of $888^{\circ} \mathrm{C}$, litharge is molten and oxidises base metals readily, which dissolve in it. Being more chemically inert, silver (and any gold impurities) is not oxidised and remains in the pure state, separate from the litharge. After cupellation, silver can be alloyed, usually with copper to improve its mechanical properties, and fashioned into objects. In effect, the presence of litharge at an archaeological site is the archaeological signature of silver production by cupellation. More significantly, however, in order to suggest that argentiferous lead ores were exploited for silver, lead slag and litharge would need to be recovered in the same context, preferably near a silver-bearing lead ore deposit.

Conventional wisdom holds that argentiferous lead ores were the main source of silver in antiquity (e.g. Forbes $\underline{1950}$, 180; Strong 1966, 3; Gale and Stos-Gale 1981b; Stos-Gale and Gale 1982; Pernicka and Bachmann 1983; Moorey 1994; Meyers 2003; Legarra Herrero 2004). This seems to have been the case at Laurion in Greece, at least from the mid-first millennium BCE. Installations at the site (e.g. washeries), slag heaps (deriving from argentiferous lead ores), historical records and coinage (such as Athenian coins, e.g. Gale et al. 1980) all attest to intensive silver production at the site (e.g. Hopper 1968; Healy 1978; Ellis Jones 1982; Rehren et al. 2002). However, re-assessment of the archaeology at Laurion resulted in earlier dates being suggested for the exploitation of these ores for silver. Finds of litharge in Bronze Age contexts at Thorikos near the mines at Laurion (Hopper 1968; Mussche 1974, 44-66; 2006) and at other sites in Attica (at Koropi, Lambrika, Markopoulo - Kakavogianni et al. 2008), as well as around the Aegean, such as on Siphnos, Seriphos, Kea and Thera (Gale and Stos-Gale 1981a) and at Limenaria on Thasos (Papadopoulos 2008), often supported indirectly by lead isotope analysis (LIA), encouraged some scholars to suggest that silver was exploited from argentiferous lead ores from the Early Bronze Age (Gale et al. 1980; Gale and Stos-Gale 1981a; Spitaels 1984; Shepherd 1993, 75; Rehren et al. 2002; Kassianidou and Knapp 2005, 220). Despite a few voices of dissent (see Treister $(\underline{1996}, 23)$ and Mussche's $(\underline{2006})$ comments on Kepper's (2004; 2005) articles), the Bronze Age dating hypothesis was a radical departure from the then prevailing view which postulated that silver production at Laurion had been stimulated, or at least advanced, by the regional demand arising from the introduction of silver coinage in the middle of the first millennium BCE (Strong 1966, 5; Hopper 1968; Kraay 1976; Healy 1978; Conophagos 1980; Weisgerber and Heindrich 1983, 196; Weisgerber and Pernicka 1995, 175), or as Ardaillon (1897, 134-6) phrased it, the 'Grande époque du Ve et du IVe siècles'.

On first inspection, evidence from archaeology and archaeological science appears consistent with the view that the argentiferous lead ores of Laurion were already the predominant silver source by the Bronze Age. However, as Perreault (2019, 2) puts it, 'archaeologists often settle on an explanation on the sole basis it can be made consistent with their data, thereby ignoring the fact that there are a 
number of alternative explanations that are just as consistent with the data'. A similar statement could be made about the few voices that dominate the field of archaeological science. Here, we provide an alternative explanation to the consensus held by many of these archaeological scientists, and it is up to the readers to decide whether we have fallen into the same trap.

The current article re-evaluates the evidence from Laurion and other Bronze Age sites and presents new compositional data for the Mycenaean shaft-grave silver (c. 1600 BCE) to investigate its provenance. We present evidence suggesting that the lead mined at Laurion and elsewhere prior to the Archaic/Classical periods was used solely to make lead objects and to extract silver from other silverbearing sources, and that argentiferous lead ores, with their invisible concentrations of silver, were only recognised as a source of silver in their own right around the middle of the first millennium BCE. This reappraisal is based on the premise that once native silver and large silver mineral ore bodies had been exhausted, silver mineralisation dispersed in host rocks was exploited by crushing and mixing the ores with molten lead, followed by cupellation. Lead was mined and transported around and beyond the Aegean (together with its LIA signature), probably by roving silver prospectors, and used as a silver collector for these 'dry' silver ores (e.g. cerargyrite), until even these sources began to run out.

Essentially, our research interrogates the potential inconsistencies in the Bronze Age dating of the commencement of silver production at Laurion. If we are correct, the trade maps for silver supply in the Aegean and beyond in the Bronze and Iron Ages need to be redrawn to reflect the original hypothesis: that argentiferous lead ores were not exploited for silver at Laurion (and elsewhere) until sometime around the birth of Classical Greece (c. 500 BCE) when having access to a local source of silver for coinage would have been a major asset.

\section{Transitions in the Sources of Silver}

Meyers $(2003,271-88)$ developed a model to describe the trajectory of ore use for silver in antiquity, based primarily on the empirical observation that gold levels are generally much lower in galena $(\mathrm{PbS})$ than in cerussite $\left(\mathrm{PbCO}_{3}\right)$ (i.e. silver objects analysed with gold contents greater than 0.1 weight per cent of gold $(0.1 \mathrm{wt} \% \mathrm{Au})$ were considered to come from cerussite rather than galena) and that silver with low gold and low lead levels derived from dry silver ores (such as cerargyrite, $\mathrm{AgCl}-$ a dry silver ore also known as horn silver). It should be noted that this second point contradicts both Patterson (1971) and Gale and Stos-Gale (1981a), who state that cerargyrite can have appreciable levels of gold (up to $1 \mathrm{wt} \% \mathrm{Au}$ ). Furthermore, although other researchers have used gold levels in silver to differentiate between cerussite and galena (Gale et al. 1980, 3-49; Pernicka 1981; Craddock 1995, 213), this limit relies on the premise that gold becomes concentrated as galena oxidises to cerussite, which would mean that the absolute levels of gold in the oxidised cerussite depend on the amount of gold present in the original deposit of galena. Nonetheless, Meyers' model proposed changes from a technology that first exploited silver ores (such as cerargyrite), followed by oxidised lead ores (i.e. argentiferous cerussite) to finally primary sulphide ores (i.e. argentiferous galena). Figure 2 is a visual representation of Meyers' model showing that the first transition was 
considered to have taken place in the third millennium BCE for the regions of Laurion/Aegean, Anatolia and Iran/Afghanistan while the second transition was in about 1000 BCE for Laurion/Aegean but not until the Arab conquest (c. $700 \mathrm{CE})$ for Anatolia and Iran/Afghanistan. The late adoption of smelting galena for silver in Anatolia and Iran is supported by archaeological field surveys (Wertime 1968; 1973; De Jesus 1980; Yener et al. 1991).

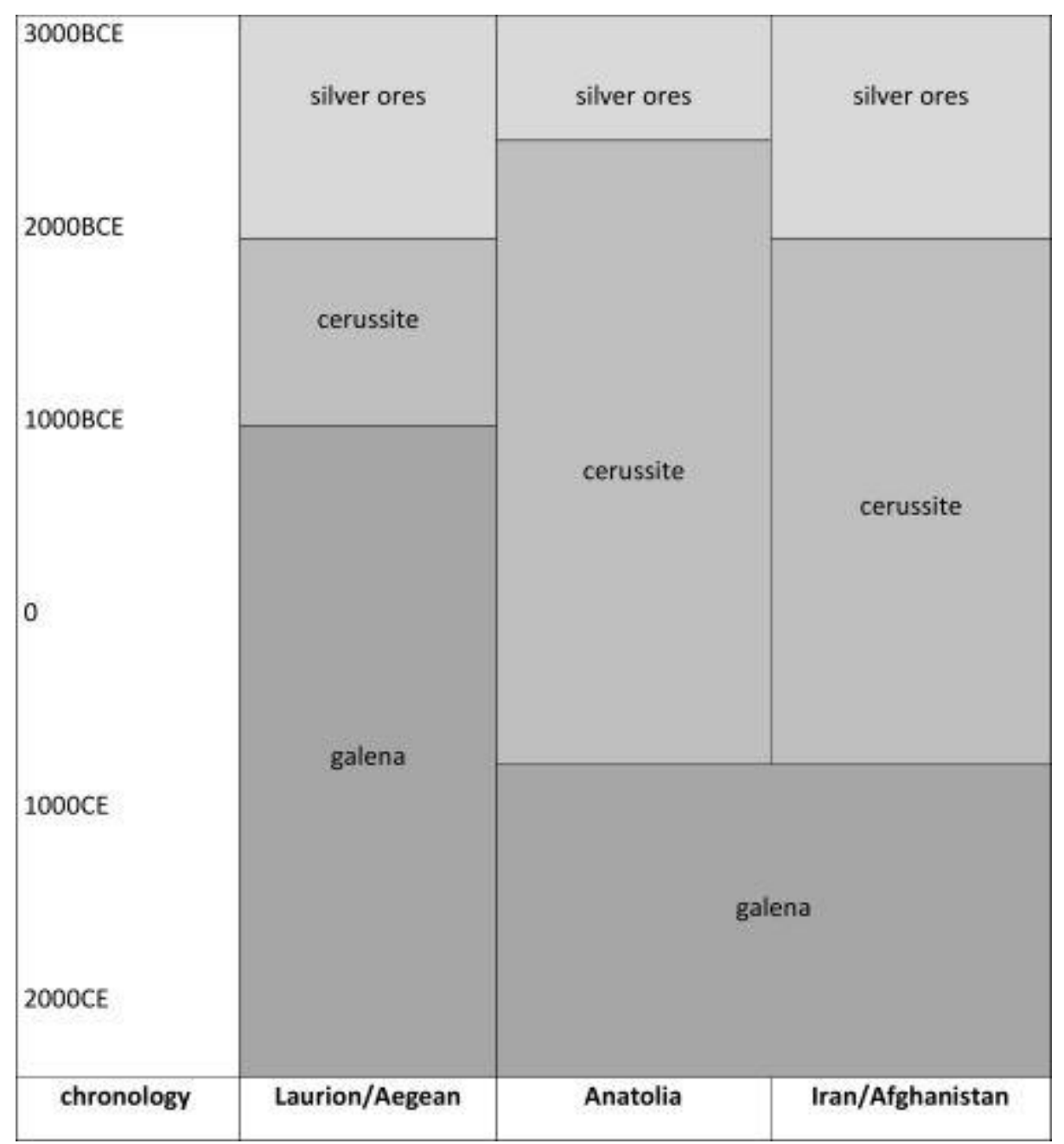


Figure 2: Visual representation of Meyers' model $(\underline{2003}, 271-88)$ for the exploitation of silver. Note the late application of galena as a silver source in Anatolia and Iran/Afghanistan

Argentiferous jarosites $\left(\mathrm{XFe}^{3+}{ }_{3}(\mathrm{OH})_{6}\left(\mathrm{SO}_{4}\right)_{2}\right.$, where $\mathrm{X}$ can be $\mathrm{K}, \mathrm{Na}, \mathrm{Pb}, \mathrm{Ag}$ and $\left.\mathrm{NH}_{4}\right)$, however, are immediately conspicuous by their absence in the model described in Figure 2. These lead-poor ores are found in Cyprus and lberia, with the latter having been exploited prodigiously by the Phoenicians, Carthaginians and Romans in the first millennium BCE (e.g. Anguilano et al. 2009; Murillo-Barroso et al. 2016; Wood et al. 2019; Wood and Montero-Ruiz 2019). More significantly, by association, the process of adding lead to extract silver from other types of ore is also omitted from Meyers' model. We would emphasise that the process of adding lead to smelt silver-bearing ores is not without precedent in antiquity. In Roman Spain, lead in the form of stamped ingots from Cartagena was added to silverbearing ores from the Corta Lago mine of Rio Tinto, some $400 \mathrm{~km}$ away (Salkield 1982, 137-47; 1987, 15). Slag from the earlier Phoenician levels at the same site suggests that exogenous lead was added, even in cases when the ores appear to have been sufficiently lead-rich, to collect silver (Anguilano et al. 2009; Murillo-Barroso et al. 2016). It has been proposed that silver was extracted from jarosite ores on Cyprus using exogenous lead (Bell and Wood in press; Wood 2019) and that local lead was used by silversmiths to refine procured lead-silver ingots (Wood and Montero-Ruiz 2019). During the 7th century BCE, this process was adapted by Lydians at Sardis who added lead to recover silver from the parting vessels and furnace linings after parting it from gold using the ancient salt cementation process (Craddock 2000, 200-11; Wood et al. 2017a). This would suggest that any model aiming to describe the ancient exploitation of silver should include lead-poor ores, such as jarosites and the argentiferous sulphosalts of Siphnos (see Section 3.1).

Changes in technology associated with silver and lead can also be inferred from changes in the frequency of finds of lead and silver artefacts as a function of time and location. Table 1, which summarises Gale's (1980, 161-96) and Stos-Gale and Gale's (1982) analysis of typological data from Buchholz $(\underline{1972}, 21-36$; Buchholz and Karageorghis $\underline{1973}, 282)$ and Branigan $(\underline{1974}, 155-205)$, highlights that the number of silver and lead objects in the archaeological record tend to decrease between the Early Bronze Age (EBA) and Middle Bronze Age (MBA) before increasing in the Late Bronze Age (LBA). This correlation was used to support the claim that silver and lead metallurgy were introduced together (Forbes 1950, 180; Gale and Stos-Gale 1981a; Stos-Gale and Gale 1982; Pernicka et al. 1983) from an older metallurgical culture, and that the Aegean people had been practising a combined silver/lead metallurgy from the EBA. In turn, this supported Renfrew's view (Renfrew 1967, 1-20) that the Early Bronze 2 period (c. 2700-2300 BCE) was a time of cultural and metallurgical intensity, followed by a recession in the MBA and eventually a resurgence in the LBA with the Minoans and Mycenaeans. To some extent, this cemented the view that silver derived from argentiferous lead ores from very early on, encouraging the application of techniques such as lead isotope analyses (LIA) to pave the way in the provenancing of silver objects by associating lead impurities in silver, slag and litharge to ores and, in some cases, ancient mines (e.g. Gale and Stos-Gale 1981a). 


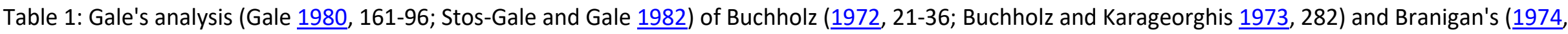
155-205) cataloguing of Bronze Age Aegean and Anatolian lead and silver objects. The possible correlation between lead and silver objects recovered in the archaeological record was used to support the exploitation of argentiferous lead ores

\begin{tabular}{|c|c|c|c|c|}
\hline & Source & EBA & MBA & LBA \\
\hline $\begin{array}{l}\text { Lead objects in the } \\
\text { Aegean and Anatolia }\end{array}$ & $\begin{array}{l}\text { Buchholz (1972, 21-36, } \\
\text { 55) }\end{array}$ & $\begin{array}{l}40 \\
\text { ( } 32 \text { in Troy, Lesbos, Lemnos, W. Anatolia and } \\
\text { central Crete. } 8 \text { from the Greek mainland) }\end{array}$ & 8 & $\begin{array}{l}199 \\
\text { (Finds shift westward toward the } \\
\text { Peloponnese, the Argolid, Attica and } \\
\text { Euboea) }\end{array}$ \\
\hline $\begin{array}{l}\text { Lead objects in the } \\
\text { Aegean and Anatolia }\end{array}$ & $\begin{array}{l}\text { Branigan (1974, 155- } \\
205)\end{array}$ & $\begin{array}{l}60 \\
\text { ( } 52 \text { from Troy, Lesbos, the Cyclades and } \\
\text { Crete. } 8 \text { from the Greek mainland) }\end{array}$ & $\begin{array}{l}12 \text { (plus } 15 \text { of } \\
\text { doubtful age) }\end{array}$ & \\
\hline $\begin{array}{l}\text { Lead objects on } \\
\text { Cyprus }\end{array}$ & $\begin{array}{l}\text { Buchholz and } \\
\text { Karageorghis } \underline{1973} \text {, } \\
\text { 282) }\end{array}$ & 0 & 9 & 74 \\
\hline Silver objects & $\begin{array}{l}\text { Branigan (1974, 155- } \\
205)\end{array}$ & $\begin{array}{l}100 \\
\text { ( } 90 \text { from Troy, Lesbos, Lemnos, W. Anatolia, } \\
\text { the Cyclades and Crete. } 10 \text { from the Greek } \\
\text { mainland) }\end{array}$ & $\begin{array}{l}22 \text { (plus } 31 \text { of } \\
\text { doubtful age) }\end{array}$ & \\
\hline
\end{tabular}

The differences in the numbers of finds between the EBA and LBA (Table 1), however, also indicate that lead/silver sources for the Aegean may have originally come from the East but that new sources in the West (i.e. Cycladic, Attic or Euboean) had begun to be exploited at the beginning of the LBA (c. 1600 BCE) (Stos-Gale and Gale 1982). This interpretation was used to identify Laurion as a possible silver supplier in the LBA, around the same time as the Mycenaean shaft-grave silver was deposited (c. 1600 BCE). Narratives 
then emerged in which silver-rich lead ores were mined at Laurion and that the Western String of islands of Kea, Melos and Thera provided Crete with secure access to metal ores (Figure 3) (Gale et al. 1984; Davis and Cherry 1990). Litharge found at Akrotiri on Thera (Gale and Stos-Gale 1981a, table 11) was interpreted as evidence for a local industry in silver smelting. Since Thera itself has neither evidence of silver mining nor lead smelting slag, it was posited that silver-rich ore or richly argentiferous lead metal from Laurion was exported for finishing elsewhere, such as Thera (Gale and Stos-Gale 1981a; Gale et al. 1984), and that the metal could then be traded throughout the Aegean and even beyond. Given that similar evidence for metallurgy has been found at Ayia Irini on Kea (ancient Keos) (Gale et al. 1984), it was further proposed that the islands of the Western String served not only as trans-shipment centres for raw ores but also as manufacturing centres producing high-quality metal goods. Because of its geographical proximity, Akrotiri in particular became Crete's major link in the all-important quest for metals (Forsyth 1997, 42-5; Gale et al. 1984; Gale and Stos-Gale 1987).

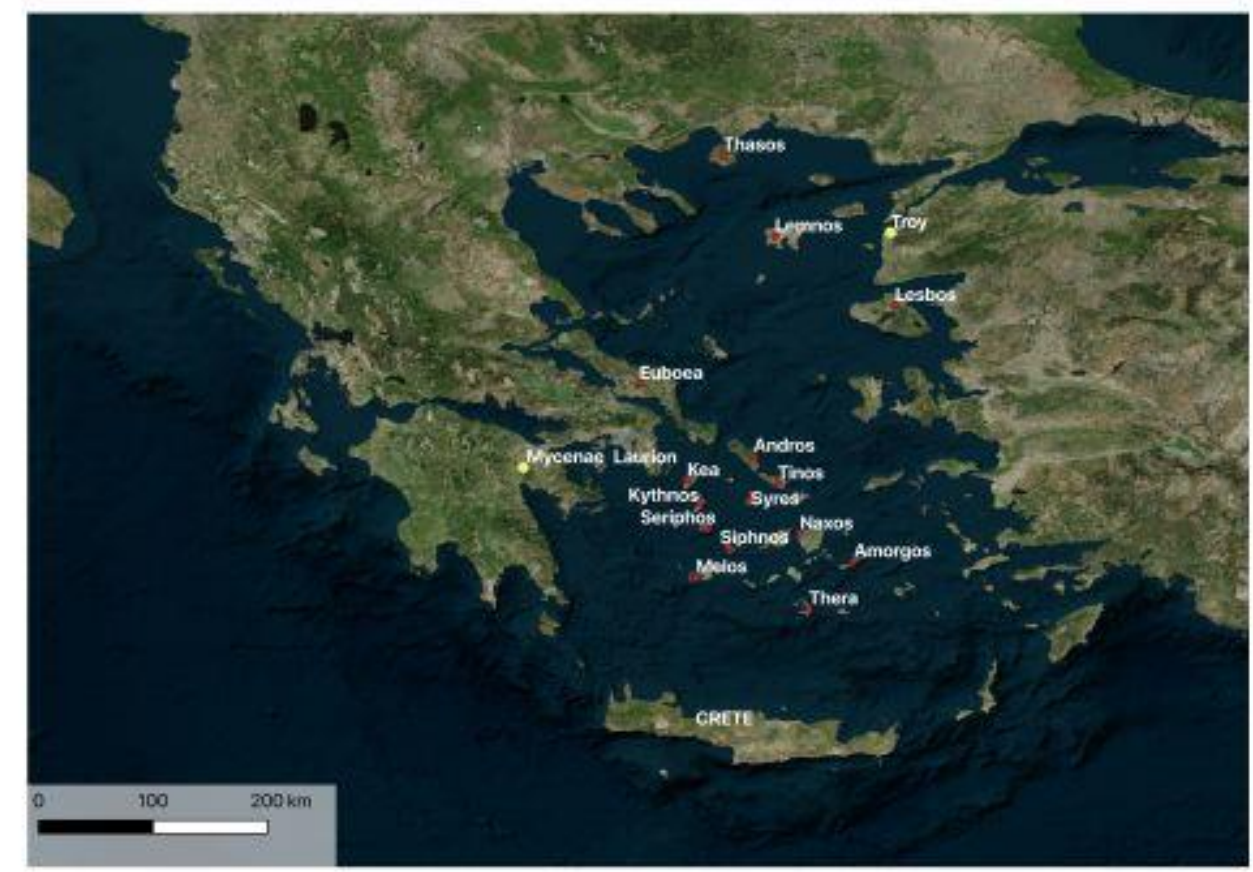

Figure 3: Map of the Cycladic islands and other sites mentioned in the text 
These narratives, however, have failed to provide an explanation for the absence of any archaeological evidence to suggest centralised control over Laurion until the Archaic period (Mussche 1998, 17-55) and for the scarcity of silver in post-shaft grave contexts (after $c$. 1600 BCE) at Mycenae (Kelder 2016, 309-19). (Author note: We appreciate that silver is not completely absent after the Mycenaean shaft-grave period as discussed by Aulsebrook (2018). Furthermore, the opulent grave goods found in an undisturbed tomb at Pylos in 2015 by the University of Cincinnati team are of interest here in that the intact tomb of an adult male (whom they named Griffin Warrior) contained a number of silver vessels (Davis and Stocker 2016; 2018). The tomb dates to LH IIA and, according to the excavators, the assemblage is an extreme example of the early Mycenaean practice to bury affluent individuals with metal (i.e. commonly bronze, as well as gold and silver), rather than ceramic, vessels (Davis and Stocker 2016). The silver vessels, once analysed, may add important insights on the sourcing of silver in the early part of the LBA.)

Furthermore, as lead smelting slag is generally absent at Bronze Age sites where litharge has been recovered, not only in Greece (e.g. Kakavogianni et al. 2008; Papadopoulos 2008) but also in Anatolia, Syria (Hess et al. 1998; Pernicka et al. 1998) and Iran (Nezafati and Pernicka 2012; Weeks 2013), the exploitation of vast amounts of galena to extract silver becomes a less viable proposition (bearing in mind that about $500 \mathrm{~kg}$ of pure argentiferous galena, plus the associated gangue minerals, would be required to produce $1 \mathrm{~kg}$ of silver). As finds of litharge are not always located in the vicinity of argentiferous lead ore deposits (e.g. Lambrika in Attica, islands in the Aegean etc.), this raises further doubt as to whether lead ores were the silver source. Furthermore, Gale and Stos-Gale (1981b) noted that of the 31 regions of lead-silver mineralisation they studied around the Aegean, many were probably not worked in the Bronze Age and some not even in Classical times. In fact, even where traces of 'ancient' mining or heaps of 'ancient' slag were identified, the period of activity was considered potentially later than the Bronze Age.

It is also difficult to reconcile the exploitation of massive deposits of argentiferous galena at Laurion from the Late Bronze Age onwards with only a single unequivocal mention of silver (a-ku-ro) in the Linear B texts (i.e. only Sa 287 from Pylos) (Kelder 2016, 309-19) and the few silver objects recovered anywhere in the Early Iron Age Aegean (Dickinson 2006, 119-20). Perhaps more significant is that only the later hacksilver hoards (i.e. Miqne-Ekron and Ein Gedi c. $600 \mathrm{BCE}$ ) of the Iron Age southern Levant have LIA signatures that are consistent with Laurion (Wood et al. 2019; Wood et al. 2020). Moreover, it is more than a little surprising that according to LIA there is no trace of Laurion silver in early Attic coins dating to before c. 530-520 BCE and that it is seldom found in Attic coins dating to before $c$. 500 BCE (Treister 1996,24$)$. This seems to be supported by LIA data from Gale et al. $(\underline{1980}$, table 6$)$ for early Attic Wappenmünzen coins (c. 545-510 BCE) (Figure 4), which show that only one coin is consistent with Laurion ores, in contrast to the Athenian coins (5th-4th centuries BCE), which group tightly within the Laurion ore LIA field (as would be expected for silver and lead derived from the same ore at one location). This could suggest that the argentiferous lead ores at Laurion only became a valuable source of silver at the time of Classical Greece. 


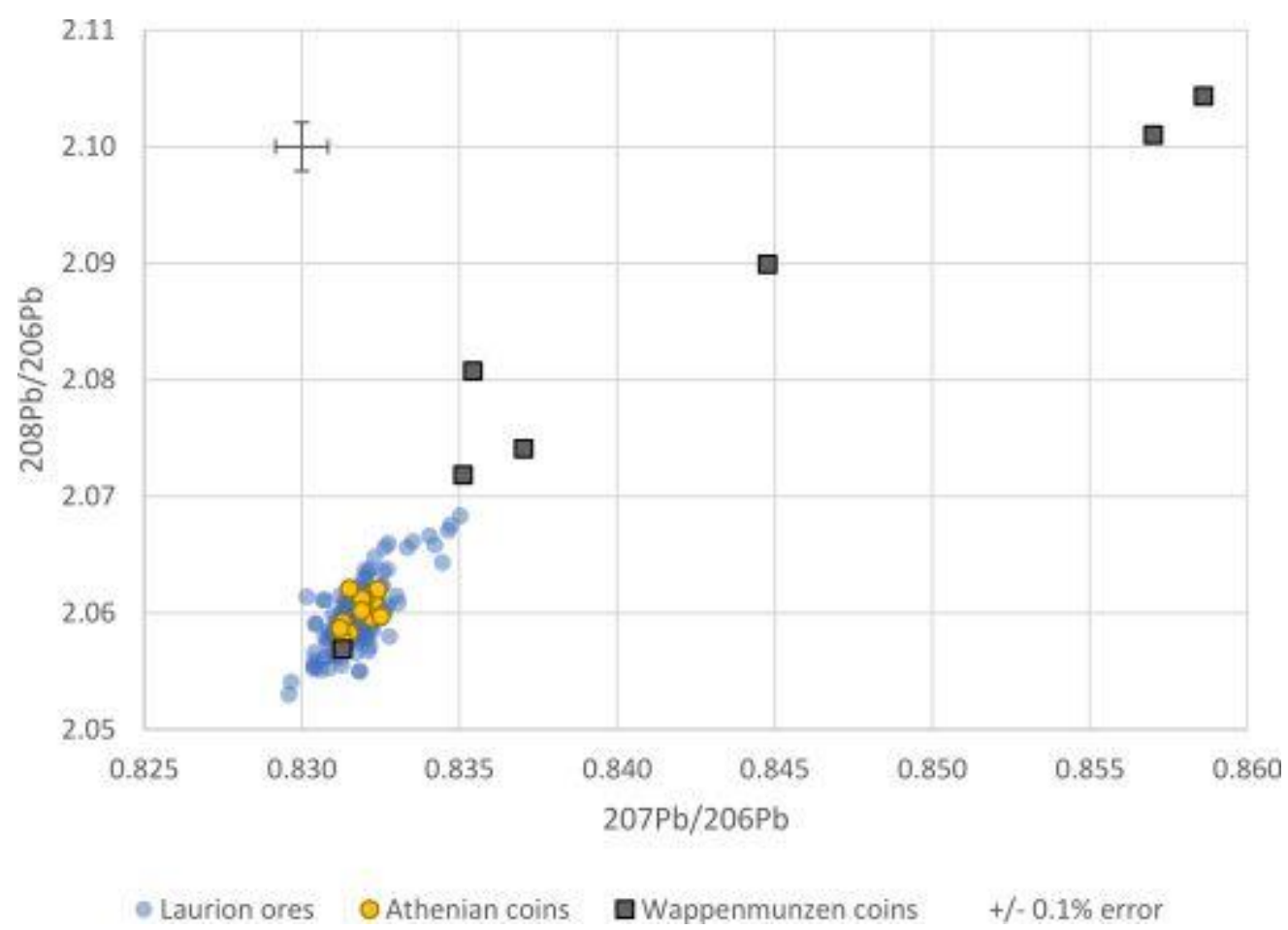

Figure 4: LIA plot of Laurion ores (OXALID 2020), Wappenmünzen coins (c. 545-510 BCE) and Athenian owls (5th-4th centuries BCE) (Gale et al. 1980, table 6). The Athenian coins are consistent with Laurion ores. Six of the Wappenmünzen coins are not consistent with the Laurion ore field. Apart from two of the Wappenmünzen coins (including one that appears to be consistent with the Laurion ore LIA field), the others have Au/Ag x100 levels greater than 0.1 (see Table 5; Gale et al. 1980, table 10), suggesting that the majority of the Wappenmünzen silver coins were not made from silver that derived from argentiferous lead ores

We believe that the common view that argentiferous lead ores, such as those at Laurion, were exploited from the Bronze Age may have arisen from an assumption that silver and lead metallurgy appear correlated archaeologically and must, therefore, have been introduced together (e.g. see Forbes 1950, 173; Gale and Stos-Gale 1981b; Pernicka et al. 1998). This view probably arose from the fact that during the fourth millennium BCE silver appeared quite suddenly over a wide area, including Mesopotamia, Iran, Anatolia and the Levant, along with evidence for cupellation in the form of litharge and other production remains (e.g. Prag 1978; Gale and Stos-Gale 1981a; Pernicka et al. 1998; Hesset al. 1998; Nezafati and Pernicka 2012; Yahalom-Mack et al. 2015). Furthermore, the number of lead objects appears to 
have increased concomitantly, which was taken to indicate that lead during the fourth millennium BCE was a by-product of silver production (e.g. Gale and Stos-Gale 1981b; Pernicka et al. 1998; Yahalom-Mack et al. 2015). In turn, this added weight to the assertion that silver recovered in the archaeological record must be geologically associated with lead, and that, in effect, ancient silver derived from argentiferous lead ores such as galena from early on. Lead and silver objects found in the same archaeological contexts have also been used to support the premise that both lead and silver must have derived from a common source (Klein and Hauptmann 2016, 136).

Consequently, it became conventional wisdom to consider that silver must have derived from argentiferous lead ores, such as the galena deposits at Laurion in Greece, without factoring in that LIA signatures of Bronze and Iron Age silver artefacts may reflect exogenous lead used to extract silver from other types of silver ore.

We contend, however, that although a correlation between lead and silver metallurgy may exist, any such correlation in the Bronze Age is not necessarily a consequence of a geological association between lead and silver in argentiferous lead ores, but because early ancient metallurgists recognised that silver and silver minerals dispersed in host rocks could be concentrated in molten lead and subsequently released from this lead by cupellation. We should emphasise that this is not a new idea. Indeed, despite proposing that lead ores, especially galena, were the chief source of silver in antiquity, Stos-Gale and Gale (1982, 467, n.1), the main champions of LIA also recognised:

'It is very probable that lead would also have been very largely used in the production and purification of silver from native silver or the dry silver ores such as argentite and cerargyrite'.

We surmise that the significance of this statement was never fully appreciated, potentially resulting in an inappropriate conflation of provenance: sources of lead within silver objects, litharge and ores (determined by measuring lead isotopes) and sources of silver were considered to be the same. Out of this, we believe, came the idea that a centralised Bronze Age silver source existed, identified from LIA as Laurion (Gale 1978; Gale 1980; Gale and Stos-Gale 1981a; Stos-Gale and Gale 1982). This, in turn, has influenced current interpretations of the circulation of metals in Bronze and Iron Age Aegean archaeology.

\section{Early Exploitation of Silver}

Unlike smelting lead ores to produce metallic lead, the extraction of silver from argentiferous lead ores is not straightforward. As well as requiring the extra cupellation step (Figure 1), it is very difficult to tell a priori how much silver, if any, there is in lead ores such as cerussite and galena. Zhou (2010) classified silver sources in terms of whether silver formed a solid solution or was found as inclusions of silver or silver minerals in the host rock. For example, silver in galena, sphalerite, pyrite, bornite, chalcopyrite, covellite, tetrahedrite and tennantite tend to form solid solutions. Consequently, the concentrations of silver found in these minerals are invisible. Conversely, 
the silver in native silver, silver-gold alloys, silver sulphides, silver tellurides, silver selenides, silver antimonides, silver sulphosalts and silver halides (e.g. cerargyrite) are incorporated as inclusions that can, in many cases, be observed with the naked eye (Figure 5).

It would be logical to suggest that the first types of ore to attract the attention of ancient miners would be:

i. ores with visible and appreciable levels of silver and/or silver minerals, and;

ii. $\quad$ ores with visible indicators that suggested they were worth exploiting.

The first type would include those mentioned above, with silver and silver minerals disseminated as visible inclusions in the surrounding rock (e.g. Figure 5); the second would include ores with visible gold, which became of interest for both gold and silver (see Bell and Wood (in press) on the exploitation in Cyprus of silver ores with visible gold particles). This would make extracting silver from argentiferous lead ores such as galena, in which the silver content is invisible, as a process to access silver in the Bronze Age, highly unlikely. Indeed, extracting silver from lead ores in this manner would make this the earliest example of invisible trace amounts of one metal being separated from another.

Smith (1967, 20-52) argued that the earliest silver objects in the archaeological record were made of native metal or of cerargyrite, both of which produce silver on melting under a cover of charcoal. Such a simple method works for relatively pure silver ores containing large crystals of a silver mineral. However, native silver and silver ores occur not only as wires and large crystals but also as plates over quartz, as dendrites inside quartz fissures, and as grains, scales and as tiny groups of crystals (Figure 5 ) (e.g. Bastin 1922). This implies that, even though silver and silver minerals may be visible to the naked eye, unless it is possible to separate it by mechanical means (e.g. selecting the purest ores and/or by crushing and milling to extract silver or silver minerals), extraction would require the ability to concentrate the silver by chemical processes. This could involve the removal of the surrounding matrix with a flux to reduce its melting point (see Wood and Hsu (2019) for a possible application of this process on cobaltiferous silver ores in Iran). Alternatively, lead could be added as a silver collector. The latter process was described by Agricola in 1556 CE (Hoover and Hoover 1950, 244) and later by Erker in 1580 CE in his treatise on ores and assaying (Sisco and Smith 1951, 37-8): 'grind the ore with a hammer until it is fine as flour...[add] granulated lead...mix the lead and ore in a scorifier'. Erker goes on to describe how the mixture is heated and the slag (from the gangue) that forms on the surface of the lead is 'knocked off', leaving the lead for cupellation.

Although not as clear as Erker (Sisco and Smith 1951, 37-8), Pliny describes such a process in the 1st century CE to extract silver from silver ores that were not lead ores (Pliny NH xxxiii, 95 - as quoted in Gale et al 1980, 4; Rickard 1928, 136; Healy 1999, 127):

'Silver is only found in pits, there being no indications to raise hopes of its existence, no shining particles as in the case of gold. The earth which it is in is sometimes red, sometimes ash-coloured. It cannot be smelted except when combined with lead, or with the vein of lead 
called galena, lead ore which is usually found running near veins of silver ore. Also when submitted to the same process of firing part of the ore precipitates as lead while the silver floats on the surface, like oil on water.'

Here Pliny is writing about underground silver mining in Iberia, which would have taken place after any surface silver had been processed. Pliny's description implies that extracting silver from ores other than argentiferous lead ores was commonly practised in the 1 st century CE. We believe that the process to which Pliny alludes, and Agricola and Erker subsequently describe, is the addition of lead metal (or pure galena) to silver-bearing ores (in Pliny's case, probably argentiferous jarosite ores) to extract silver. In effect, after such an operation (which is presumably smelting argentiferous ore with added lead), the silver would be present entrapped within the lead and/or in solution and could undergo subsequent cupellation.

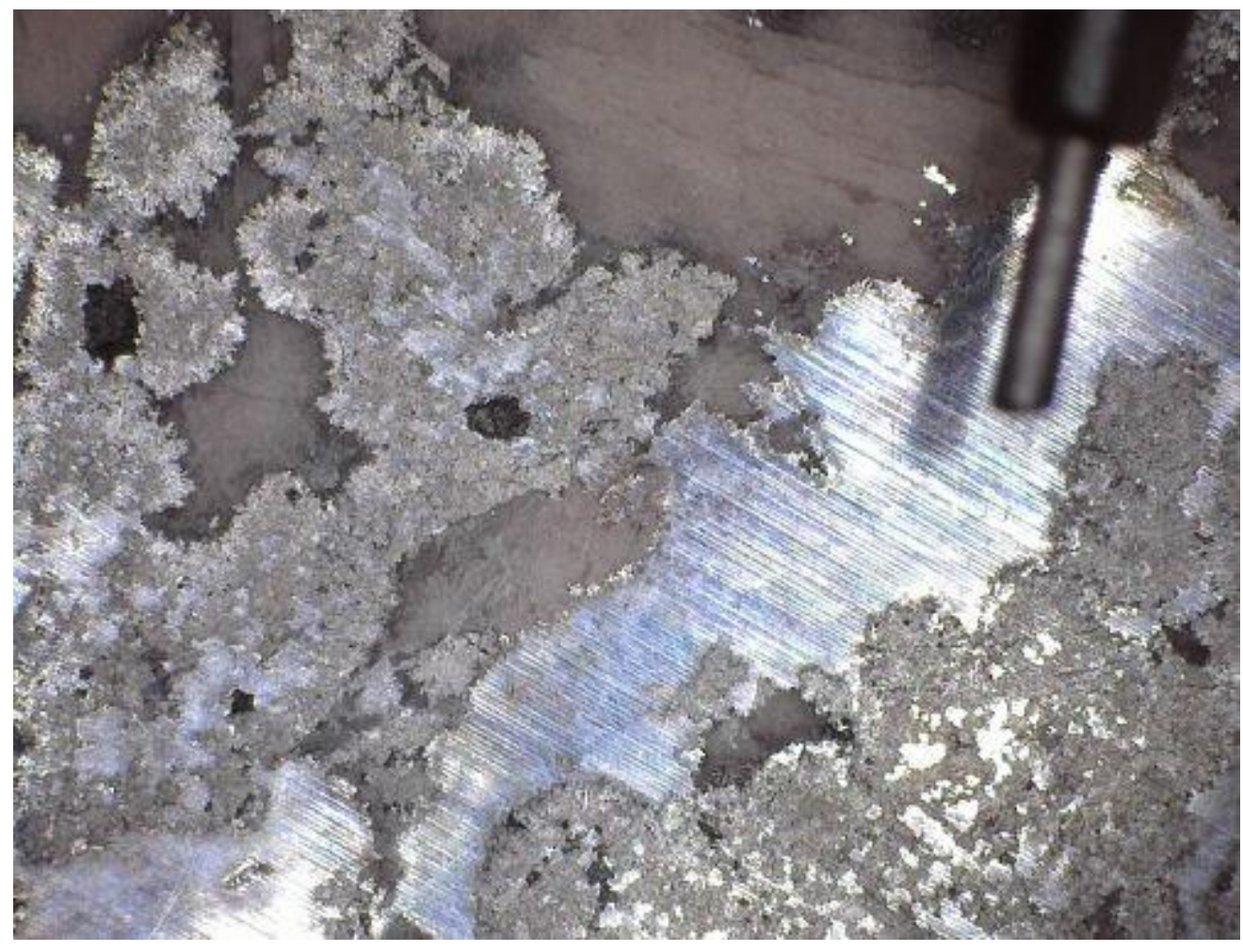

Figure 5: Native silver dispersed in a host rock. The surface has been coarsely polished to make the silver visible 
Arguments have been put forward, however, that the easily accessible resources of native silver and large silver minerals had already been exhausted by the Late Bronze Age (e.g. Meyers 2003; Craddock 2014), which would provide conditions that would support an early date for the transition to using argentiferous lead ores. Unfortunately, retrospective evaluations of mining areas are notoriously difficult to make. For instance, the ancient mines in Cyprus and lberia were obliterated in the 20th century CE and Laurion was worked on an industrial scale during the Classical period and in modern times. Nevertheless, comparisons have been made with other mining regions to reconstruct the prospecting of mines such as Thorikos/Laurion (Krysko 1988). For example, Mussche (2006, 225-6), the director of excavations at Thorikos, commented on a worked vein at Mine no. 3:

'We logically presume that two conditions had been present: open-cast mining combined with highly rich mineral...we can imagine a situation in Thorikos similar to that of 19th century Australia, in the Long Reef region, where a mineral with ca. $60 \%$ silver content was found in the surface in the "Day Dream" and "Maybell" mines.'

Mussche $(2006,225-6)$ appears to claim that mining at Laurion initially focused on minerals with high concentrations of silver rather than argentiferous lead ores. Interestingly, Krysko (1988, 88-92) highlights the order in which the Long Reef mines in Australia were exploited: first the rich minerals (which first attracted the prospectors), then the oxidised zones (i.e. silver minerals, native silver, anglesite,

cerussite) and finally the sulphidic galena. This is similar to the trajectory proposed by Meyers (2003) (Figure 2). Furthermore, at 'Broken Hill' lode, after the hard iron crust of the gossan was broken, '[19th century CE miners] found themselves in an Aladdin's cave: native silver, silver chloride, silver bromide, silver sulphide, cerussite, anglesite, and also some galena as well as gangue minerals' (Krysko 1988, 90). Unlike Meyers' model, this would suggest that cerussite $\left(\mathrm{PbCO}_{3}\right)$ was not necessarily the source of silver exploited in oxidised zones. In fact, Krysko's observations are reminiscent of Gale and Stos-Gale's idealised cross-section through a weathered ore vein (Gale and Stos-Gale 1981a, fig. 1). Gale (1980, 163) comments:

'Below the leached zone in a lead/zinc deposit occurs an oxidised zone, just above the water table. This oxidised zone often contains cerargyrite $(\mathrm{AgCl})$ and native silver mixed with some cerussite and anglesite. It is conceivable that early man may have made some minor use of both native metal and chloride ore (easily reduced to the metal) as a source of silver...'

Gale (1980) clearly acknowledges that cerargyrite is present in the oxidised zone and could have been exploited, although he fails to recognise that as this oxidised zone was mined, more silver-bearing minerals could have become available which might have continued to be exploited throughout the Bronze Age.

Krysko $(1988,90-1)$ further comments that in the early phases of exploitation at Long Reef, the silver concentrations were so high it made smelting operations easy using only the simplest charcoal furnaces, and that the cupellation process produced little litharge. A similar sequence of events may have taken place at Laurion: perhaps it was first exploited for its easily accessible ores before the 
infrastructure and technology was deployed to be able to access the low concentrations of silver in the sulphidic ore body, with its concomitant increase in gangue minerals. This would also provide an explanation for the low amounts of Bronze Age litharge recovered in Attica and around the Aegean (see Section 3.5).

Moreover, Krysko's (1988) observations suggest that the silver output from the silver-rich oxidised zone was limited, owing to the size of the ore body. This would suggest that after large silver minerals had been exhausted, lead was potentially required to extract the more technologically challenging silver minerals that were dispersed in host rocks, until even these relatively accessible sources of silver began to run out. In fact, the finite size of the oxidised zone would provide an explanation for the scarcity of silver during and immediately after the Bronze Age. In effect, the exploitation of silver minerals found in oxidised zones is potentially observed in how the numbers of silver objects recovered change with chronology (Table 1), a pattern that is difficult to attribute to the extraction of silver from a plentiful supply of argentiferous lead ore.

Geologically, the Laurion district belongs to the Cycladic-Pelagonian belt, which includes base and precious metal mineralisation such as that at south Evia, Tinos and Siphnos (Skarpelis 2002). This would suggest that many Aegean islands including Euboea, Mykonos, Tinos and Kythnos potentially have (or had) similar mineralisations (Voudouris et al. 2008). For example, the island of Melos, the most southwestern island in the Cyclades group, has silver-rich deposits and gold dispersed in quartz veins (Kilias et al. 2001). Furthermore, if silver minerals dispersed in host rocks were available near the lead ores of Laurion and at other locations around the Aegean (and beyond), ancient miners could have started to extract these visible inclusions, potentially using lead from Laurion, with a similar resolve to their exploitation of native silver and large silver minerals. In fact, the presence of gold particles may have been the catalyst that resulted in their exploitation and could suggest that silver with gold impurities derived from dry silver ores associated with gold. This will be discussed in the following sections.

Essentially, it is possible that prospectors went in search of dry silver ores, taking some lead with them, resulting in an increase in the amount of lead in circulation and an increase in the amount of silver being extracted. This explanation does not require recourse to the assumption that a correlation between lead and silver exists because they are associated geologically in the same mineral.

\subsection{Silver mining on Siphnos}

One of the earliest places where silver appears to have been exploited is the island of Siphnos (Pernicka and Wagner 1985 ). Only Siphnos has evidence for Bronze Age mining in the Aegean (Gale and Stos-Gale 1981a). The silver-producing ores of Siphnos are not galena but primarily a complex mixture consisting of lead-antimony sulphosalts that contain silver (Meyers 2003, 271-88). Tylecote $(1987,88)$ states explicitly that the ores on Siphnos were 'almost certainly jarosites', potentially similar to the jarosite ores of Iberia and 
Cyprus. Vavelidis et al. (1985) also note the presence of jarosite in their geological surveys. Iron compounds of pyrite $\left(\mathrm{FeS}_{2}\right)$ and limonite $\left(\mathrm{FeO} \cdot \mathrm{nH}_{2} \mathrm{O}\right)$ are recorded, with silver described as being disseminated rather sparsely in the host iron ore (Gale et al. 1984). In fact, the ores of Siphnos, which occur in a gossan, do not have a particularly promising appearance, although compounds containing silver are often distinguishable as yellow ore inclusions. The period of silver production from these lead-antimony sulphosalts is purported to extend from the Early Bronze Age (EBA) to the 5th century BCE (Wagner et al. 1980; Gale and Stos-Gale 1981a; Wagner and

Weisgerber 1985, 230). Datable archaeological material reveals that mining in Siphnos ceased c. 500 BCE (Pernicka and Wagner 1985 ; Birch et al. 2020), perhaps due to flooding, as mentioned by Pausanias (X, II.2 - as quoted in Gale et al. 1980).

The mineralisation on Siphnos could suggest that there was sufficient lead associated with Siphnian silver ores to collect the silver during the smelt (as advocated by Gale et al. 1980; Gale and Stos-Gale 1981a, 197), or that lead was available that could be added to the smelt in order to produce argentiferous lead. In both cases, subsequent cupellation would retrieve the silver from the lead. However, a cursory look at the ores from Ayios Sostis on Siphnos (Table 2) shows that lead concentrations in the ores vary quite considerably, indicating that the amounts of silver worth exploiting are not always associated with high levels of lead. This would be expected considering the list of minerals associated with silver-bearing ores on Siphnos (see also Vavelidis et al. 1985, 79, table 3) and would also suggest that the term 'lead-antimony' sulphosalts is perhaps not completely appropriate.

More significantly, the final column in Gale et al.'s table $2(\underline{1980})$ (reproduced here in our adapted Table 2 ) shows the amount of silver in parts per million by weight (ppm) in lead. This column, however, is misleading, as it suggests that silver is located within the lead, which is not necessarily the case.

Table 2: X-ray fluorescence (XRF) analyses (in weight per cent) of ores from Ayios Sostis, Siphnos. (s= standard deviation; nd = not determined) (adapted from Gale et al. 1980, table 2). The final column is misleading, as exemplified by sample TG43-20, i.e. lead cannot dissolve $8.3 \mathrm{wt} \%$ of silver in the solid state (see Figure 6)

\begin{tabular}{|c|c|c|c|c|c|c|c|c|c|c|c|c|c|c|}
\hline Ore No. TG\# & $\mathrm{SiO}_{2}$ & $\mathrm{P}_{2} \mathrm{O}_{5}$ & $\mathrm{~K}_{2} \mathrm{O}$ & $\mathrm{CaO}$ & $\mathrm{TiO}_{2}$ & MnO & $\mathrm{FeO}$ & $\mathrm{Cu}$ & $\mathrm{Zn}$ & As & $\mathrm{Pb}$ & Sb & Ag ppm & $\begin{array}{l}\mathrm{Ag}(\mathrm{ppm}) \text { in } \\
\text { lead }\end{array}$ \\
\hline $43-10$ & 7.20 & 0.70 & 0.00 & 4.70 & 0.00 & 0.20 & 0.70 & 0.3 & 0.2 & 0.0 & 83.9 & 0.0 & 3000 & 3576 \\
\hline $43-11$ & 5.90 & 3.90 & 0.00 & 1.80 & 0.00 & 0.50 & 15.40 & 0.3 & 0.3 & 6.4 & 58.9 & 0.0 & 200 & 340 \\
\hline
\end{tabular}




\begin{tabular}{|c|c|c|c|c|c|c|c|c|c|c|c|c|c|c|}
\hline $43-13$ & 3.20 & 0.00 & 0.00 & 2.40 & 0.00 & 0.40 & 4.20 & 0.6 & 22.3 & 0.0 & 38.3 & 4.0 & 700 & 1828 \\
\hline $43-15$ & nd & nd & nd & 10.20 & 0.00 & 0.90 & 3.50 & 37.5 & 2.2 & 0.0 & 2.3 & 1.8 & nd & nd \\
\hline $43-16$ & 0.00 & 0.00 & 0.00 & 2.80 & 0.10 & 1.20 & 38.50 & 0.2 & 30.9 & 0.1 & 1.3 & 1.4 & 65 & 5000 \\
\hline $43-19$ & 6.90 & 1.10 & 0.00 & 4.70 & 0.00 & 0.90 & 7.70 & 0.5 & 0.4 & 0.8 & 67.6 & 0.8 & 4800 & 7101 \\
\hline $43-20$ & 1.70 & 0.00 & 0.00 & 32.20 & 0.10 & 0.20 & 3.90 & 14.4 & 15.9 & 0.3 & 1.8 & 0.2 & 1500 & 83333 \\
\hline $43-22$ & 3.00 & 0.30 & 0.20 & 27.50 & 0.10 & 0.20 & 1.10 & 0.3 & 0.7 & 1.3 & 25.6 & 23.6 & 1800 & 7031 \\
\hline $43-36.1$ & 3.60 & 0.00 & 0.00 & 8.20 & 0.00 & 3.30 & 4.10 & 13.9 & 1.5 & 0.1 & 34.5 & 20.4 & 1900 & 5507 \\
\hline $43-36.2$ & 0.00 & 0.00 & 0.00 & 12.50 & 0.10 & 4.80 & 41.00 & 1.0 & 0.5 & 0.0 & 5.4 & 1.7 & 90 & 1667 \\
\hline $43-36.3$ & 2.10 & 0.30 & 0.50 & 30.00 & 0.10 & 0.20 & 0.20 & 5.3 & 1.1 & 6.8 & 48.1 & 1.5 & 2400 & 4990 \\
\hline mean & 3.4 & 0.6 & 0.1 & 12.5 & 0.0 & 1.2 & 10.9 & 6.8 & 6.9 & 1.4 & 33.4 & 5.0 & 1646 & 12037 \\
\hline s & 2.6 & 1.2 & 0.2 & 11.7 & 0.1 & 1.5 & 14.9 & 11.6 & 10.9 & 2.6 & 29.1 & 8.5 & 1504 & 25154 \\
\hline median & 3.1 & 0.15 & 0.0 & 8.2 & 0.0 & 0.5 & 4.1 & 0.6 & 1.1 & 0.1 & 34.5 & 1.5 & 1650 & 4995 \\
\hline
\end{tabular}


In fact, only low concentrations of silver can dissolve in lead, the solubility being 0.19wt\%Ag (Predel et al. 2004, 25-26) or 0.099wt\%Ag (i.e. 990ppm) (see Figure 6). This would suggest that concentrations of silver in excess of 990ppm would not be in solution in the lead. This has repercussions for the exploitation of silver from Siphnian ores. Whereas silver resides within the lead mineral in argentiferous lead ores (e.g. galena) prior to smelting, and in the lead after smelting (either in solution or mechanically entrapped), silver in the ores in Siphnos would have either dissolved in any lead present (up to the solubility limit) or remained separate. This suggests that, during the smelting operation, any silver above the low concentrations in solution with the lead associated with the ore will remain with the other components as part of the gangue. In effect, to extract silver from a mineral system such as that found on Siphnos, sufficient lead would be required to be in direct contact with the silver phase. This would potentially require grinding the ore up (probably after removing as much gangue as possible), in order to provide a large area of interaction, and heating it with a mass of molten lead to dissolve and/or to envelop any silver present (as described by Erker in his 16th-century CE treatise). Furthermore, a physical property of the lead-silver mixture is that, if re-melted and cooled, the first crystals formed will consist of pure lead and the remaining solution will become richer in silver. This formation of pure lead crystals will go on until the remaining lead contains about $2.5 \mathrm{wt} \%$ of silver (i.e. the eutectic composition) (Figure 6). The remaining molten metal will solidify immediately. By pouring off the molten metal before this happens, the silver may be concentrated as much as possible and the enriched lead can be de-silvered by cupellation (Forbes $\underline{1950}$, 205).

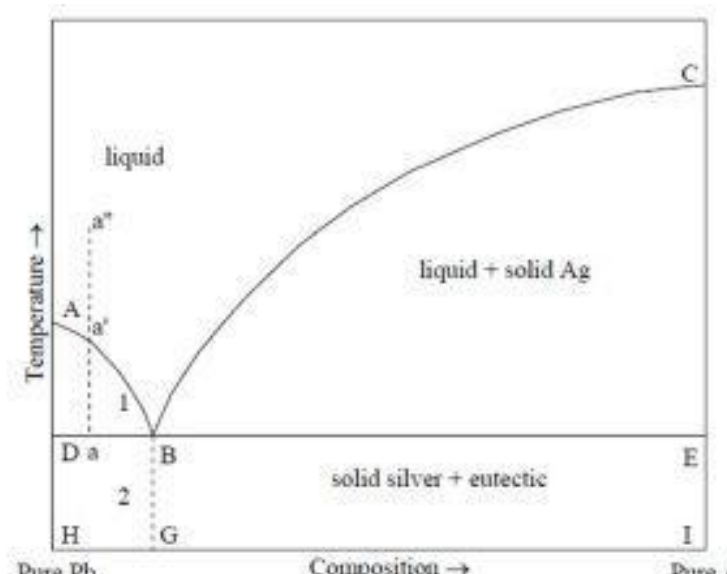

Figure 6: Simplified phase diagram of lead-silver system. 1. Liquid + solid $\mathrm{Pb}$ and 2. Solid + $\mathrm{Pb}$ eutectic. Melting point of lead (point $\mathrm{A}: 327.5^{\circ} \mathrm{C}$ ); melting point of silver (point $\mathrm{C}: 962^{\circ} \mathrm{C}$ ). The dashed line $\mathrm{B}-\mathrm{G}$ corresponds to the eutectic composition of $2.5 \mathrm{wt} \% \mathrm{Ag}$. The solubility of silver in lead is so small that it cannot be drawn on this diagram (i.e. $0.099 \mathrm{wt} \% \mathrm{Ag}$ ). The process of heating argentiferous lead containing a very small quantity of silver and cooling to get pure lead and liquid richer in silver is now known as Pattinson's process. This process can be understood by following the phase diagram of the Ag- $\mathrm{Pb}$ system. The argentiferous lead is melted and heated to a temperature above the melting point of pure lead. Point a" represents this system on the 
diagram. As the system cools slowly and the temperature of the melt decreases along a"-a', the solid lead starts separating at a'. As the system further cools, more and more lead separates and the liquid in equilibrium with the solid lead gets richer in silver. The lead that separates can be continuously removed by ladles. When the temperature of the liquid reaches a on the line DBE (the eutectic temperature), solid lead is in equilibrium with the liquid having the composition $\mathrm{B}$. The liquid is cooled further when it solidifies to give a mixture of lead and silver having the eutectic composition of $2.5 \mathrm{wt} \%(25000 \mathrm{ppm})$ of silver. This solid mixture of lead and silver can then undergo cupellation to recover the silver. Adapted from Karakaya and Thompson (1987)

The archaeological evidence on Siphnos, to a certain extent, supports the possibility that this process was used. First, the employment of such a process may begin to explain the purpose of crucible fragments at Ayios Sostis, since details are 'unclear as to the technical execution of the process' carried out to extract silver (Weisgerber and Pernicka 1995,175 ), i.e. crucibles could have been used to melt and pour the lead into scorifiers. Second, the small and heavy, semi-rounded, hazelnut-sized pieces of slag that are found together with the litharge on Siphnos are very different to tapped slags found at 5th- and 4th-century BCE Laurion (Figure 7). This could suggest that the Bronze Age Siphnian slag was very viscous, something perhaps substantiated by the fact that only three of the eleven ores in Table 2 could have been self-fluxing at temperatures of $1200-1300^{\circ} \mathrm{C}$ (Gale and Stos-Gale 1981a). This would immediately indicate that the slag was not produced from melting rock but from melting lead with crushed ore. Third, although numerous tuyères have been recovered, which are believed to be prehistoric (Wagner and Weisgerber 1985, 231), none of the fragments show any traces of slag, which could suggest that they were not used in a smelting furnace but for heating crucibles. 


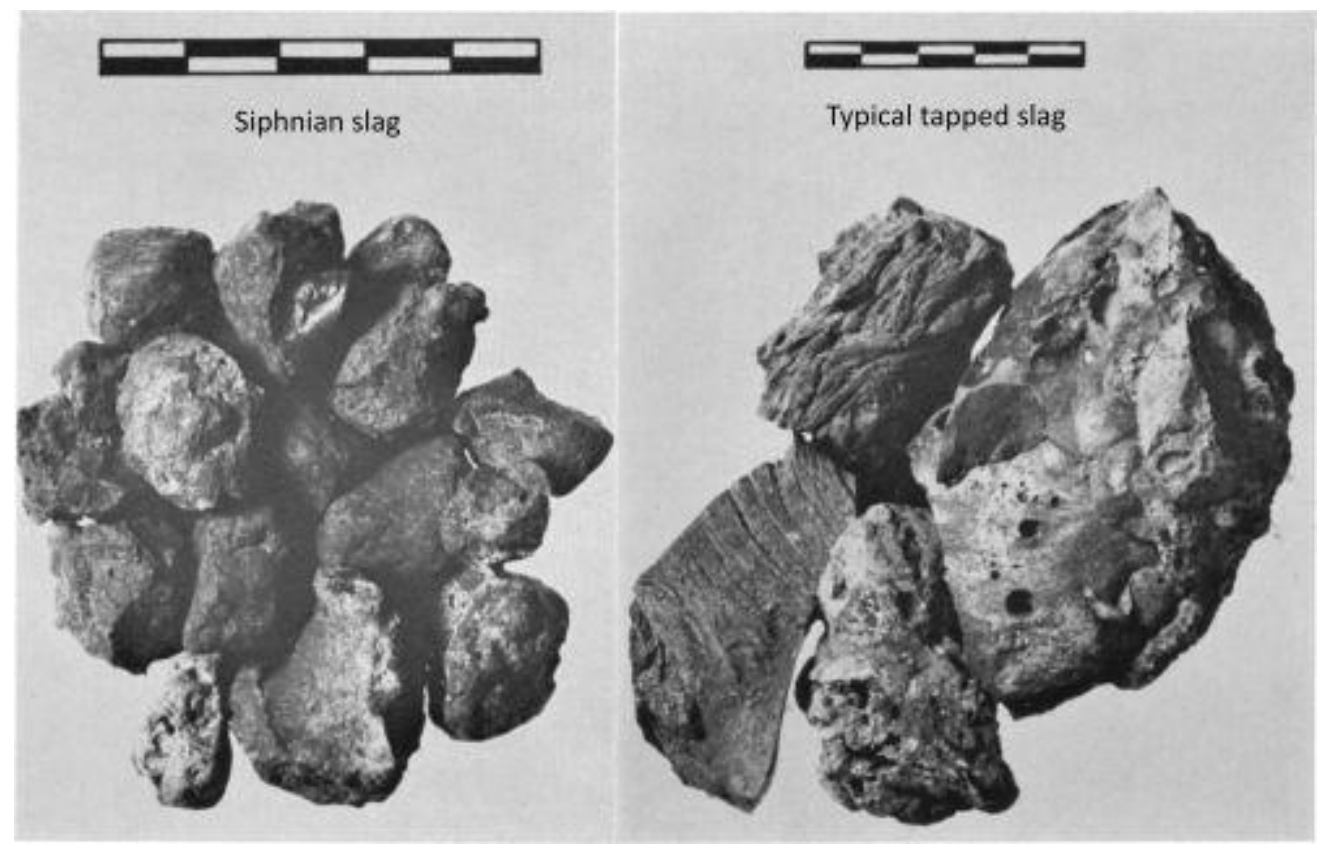

Figure 7: (left) Bronze Age slag from Ayios Sostis, Siphnos. (right) Typical large tapping slag from 4th-century BCE lead-smelting furnace installations at Pountazeza, Panormus and Laurion. (adapted from Gale and Stos-Gale 1981a, pl. 40)

Furthermore, some of the slag recovered at Ayios Sostis not only has high levels of lead (Gale et al. 1980, table 12), which would be consistent with lead being added to the crushed ore, but also contains entrapped lead phases with concentrations of silver generally consistent with the solubility of silver in lead (Gale et al. 1980 , table 13).

Based on these observations, a possible mechanism for silver extraction from Siphnian ores could be as follows:

i. Crushed argentiferous ores were placed in a scorifier with lead and heated (or molten lead was poured on), perhaps in pit furnaces, using tuyères.

ii. Since the first crystals formed after melting argentiferous lead are almost pure lead, they would be denser and sink to the lowest part of the scorifier (see Forbes' $(\underline{1950}, 206)$ interpretation of Pliny NH xxxiv, 159). Alternatively, these first crystals could have been removed. 
iii. The portion that remained longest as a liquid would become much richer in silver and could have been ladled out or poured off to be treated separately for silver (i.e. cupellation).

iv. What remained would be the mechanically crushed gangue held together by lead (i.e. entrapped lead with low concentrations of silver) that had solidified against the bottom of the scorifier.

Regardless of the specific details of the process, any lead produced to be later cupellated could have up to 25000ppm of silver (i.e. the eutectic composition). This is at least an order of magnitude higher than lead smelted from argentiferous lead ores, which are usually no more than 2000ppm (see Table 3). Perhaps more importantly for the ancient silver producer is that, unlike the invisible and variable silver concentrations found in argentiferous lead ores, this process would always produce lead to be cupellated that contained significant levels of silver. In fact, even if silver was not concentrated in the lead (contra Forbes's $(\underline{1950}, 206)$ interpretation of Pliny $N H$ xxxiv, 159), the ancient silver producer would still be aware that silver had been collected by the added lead which would warrant subsequent cupellation.

From the mechanism proposed, we suggest that utilisation of this process on Siphnos to extract silver from Siphnian ores would require the addition of lead (contra Gale et al. 1980). This is now examined by considering LIA analyses of Aegean Bronze Age lead objects.

Figure 8 shows that finds of lead objects recovered round the Aegean in Bronze Age contexts fall within two main LIA fields, identified by Gale as Laurion $\left({ }^{207} \mathrm{~Pb} /{ }^{206} \mathrm{~Pb} \lesssim 0.835\right)$ and Siphnos $\left({ }^{207} \mathrm{~Pb} / 206 \mathrm{~Pb} \gtrsim 0.835\right)$ (Gale and Stos-Gale 1981a). These limits approximately signify the ore fields, as plotted in Figure 9. 


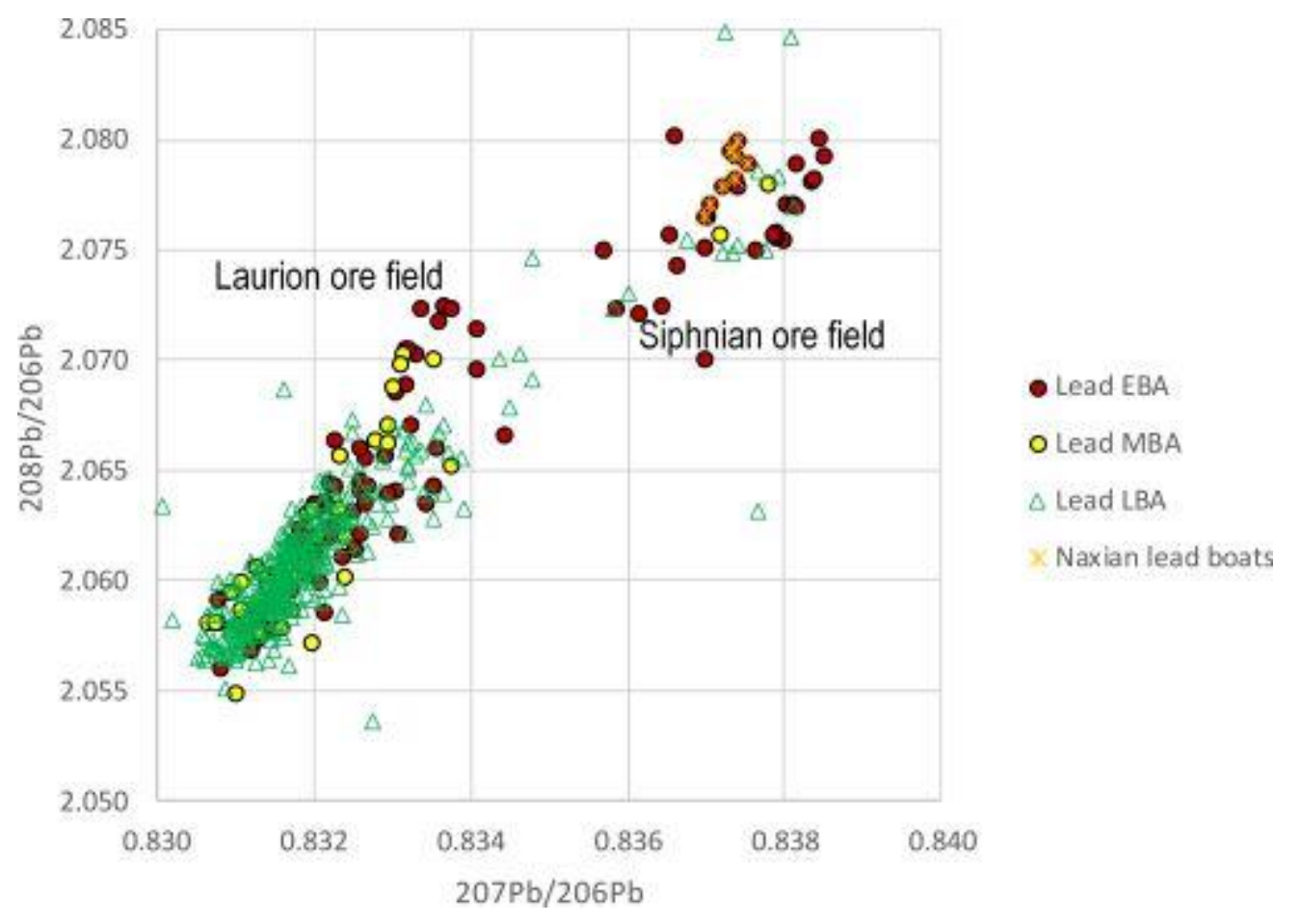

Figure 8: LIA plot of Bronze Age lead objects (OXALID 2020) from Crete, islands in the Cyclades (Amorgos, Antiparos, Despotiko, Kea, Makronisos, Naxos, Syros, Melos, Paros, Thera), the Dodecanese (Rhodes) and the Saronic Gulf (Dokos) and the Greek mainland (Argolid, Messenia, Thebes, Thessaly, Attica, Boeotia) delineated by chronology. The objects fall into two main groups that are consistent with the Laurion and Siphnian ore LIA fields identified by Gale and Stos-Gale (1981a). The lead boat models recovered on Naxos lie within the Siphnian ore LIA field. Some objects from the LBA have higher ${ }^{207} \mathrm{~Pb} / 206 \mathrm{~Pb}$ values which are not shown due to scale

Figure 8 indicates that Laurion was a major producer of lead from the EBA onwards, with Siphnos contributing to a lesser degree, especially in the MBA. The large number of lead objects found with Laurion LIA signatures is essentially uncontentious, as galena sources at Laurion are well documented. On the other hand, Siphnos has very few galena sources (Wagner et al. 1980, 63-85). In fact, galena deposits on the Greek islands are mostly fairly small (Stos-Gale et al. 1995) and any evidence for their exploitation in the Bronze Age or the early Iron Age (EIA), in the shape of securely dated lead slags, is limited. Nonetheless, the Early Cycladic Naxian lead boat models, first examined by Renfrew at the Ashmolean museum in Oxford (Renfrew 1967, 1-20), have Siphnian LIA signatures (see Figure 
8) (Gale 1978; 1980; OXALID 2020), which supports the proposition that lead from Siphnos was exploited and exported to other islands in the EBA (note: the authenticity of these objects has been questioned - see Sherratt 2000, 100-9). The number of LIA data for lead objects that lay within the Siphnian ore field compared with those of the Laurion LIA field throughout the Bronze Age could therefore reflect dwindling sources of lead on Siphnos. This would also appear to be uncontentious, until it is recalled that lead was potentially needed to extract Siphnian silver from its ores. This could suggest that ancient smelters on Siphnos would have required lead from other sources. In effect, Siphnos, which was producing silver until the 5th century BCE, had silver dispersed in ore deposits but not necessarily enough indigenous lead to extract it.

\subsection{Bronze Age silver objects}

Table 3 shows compositional data from a sample of the ores from Laurion, including the gold to silver $(\mathrm{Au} / \mathrm{Ag} \times 100)$ ratios. The silver concentration in Laurion ores ranges between 70ppm and 4760ppm (Gale et al. $\underline{1980}$ ), which is comparable to the Siphnian ores in Table 4 (range: $5.8 \mathrm{ppm}-4490 \mathrm{ppm}$ ). Both datasets have similar mean silver concentrations but Laurion shows much higher variation (average silver concentrations - mean: Laurion 1357ppm; Siphnos 1671ppm; median: Laurion 610ppm; Siphnos 1585ppm). It should be noted that the column recording the amount of silver in lead (ppm) at Laurion has validity for these argentiferous galena ores, i.e. silver would be in direct contact with the lead.

Table 3: Compositional data from neutron activation analysis (NAA) of Laurion ores (from Gale et al. 1980); $s$ is the standard deviation. Values in italics are from Gale and Stos-Gale (1981a) - not all elements were measured $(\mathrm{nm})$ for these data. We assume here that lead was approximately $86 \mathrm{wt} \% \mathrm{~Pb}$, in accordance with the concentrations found in pure galena ores

ppm

Laurion ores
$\mathrm{Ag}$

350

$\mathrm{Au}$

0.003
$\mathrm{Cu}$

820

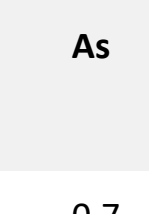

0.7
$\%$

Cd

Zn

$\mathrm{Pb}$

Fe

ppm Ag in

$\mathrm{Au} / \mathrm{Ag} \times 100$
340

1390

310

6.1

68.7

3.5

504

0.0069 


\begin{tabular}{|c|c|c|c|c|c|c|c|c|c|c|c|}
\hline 200 & 0.009 & 1970 & 16.3 & 100 & 2860 & 900 & 23.5 & 31.4 & 15.4 & 637 & 0.0045 \\
\hline 310 & 0.035 & 290 & 580 & 260 & 6240 & 240 & 6.8 & 59.5 & 5.8 & 521 & 0.0113 \\
\hline 1240 & 0.260 & 310 & 4200 & 1300 & 25 & 20 & 0.2 & 38.0 & 15.5 & 3263 & 0.0210 \\
\hline 720 & 0.055 & 950 & 0.9 & 16 & 5200 & 620 & 12.7 & 43.0 & 8.4 & 1674 & 0.0076 \\
\hline 800 & 0.102 & 400 & 3.5 & 28 & 1070 & 260 & 5.1 & 57.0 & 6.1 & 1404 & 0.0128 \\
\hline 70 & 0.090 & 2330 & 310 & 57 & 2300 & 270 & 7.5 & 1.7 & 37.6 & 4118 & 0.1286 \\
\hline 4400 & 0.050 & 1420 & 5.0 & 9150 & 190 & 20 & 0.02 & 84.6 & 0.2 & 5201 & 0.0011 \\
\hline 4760 & 0.070 & 910 & 45 & 10700 & 870 & 60 & 0.4 & 80.4 & 0.8 & 5920 & 0.0015 \\
\hline 790 & 0.020 & 940 & 860 & 700 & 270 & 1800 & 37.1 & 22.1 & 5.1 & 3575 & 0.0025 \\
\hline 1900 & 0.005 & 200 & 180 & 2400 & 2 & 30 & 0.2 & 82.5 & 0.8 & 2303 & 0.0003 \\
\hline 110 & 0.130 & 400 & 9000 & 130 & 200 & 1800 & 50.6 & 3.4 & 7.3 & 3235 & 0.1182 \\
\hline 500 & 0.008 & 180 & 3.0 & 390 & 50 & 40 & 0.1 & 86.3 & 0.2 & 580 & 0.0016 \\
\hline 402 & 0.006 & 547 & 3.0 & 450 & $n m$ & $n m$ & $n m$ & $86 ?$ & $n m$ & 467 & 0.0015 \\
\hline
\end{tabular}




\begin{tabular}{|c|c|c|c|c|c|c|c|c|c|c|c|c|}
\hline & 443 & 0.071 & 2874 & 0.2 & 19 & $n m$ & $n m$ & $n m$ & $86 ?$ & $n m$ & 515 & 0.0160 \\
\hline & 4722 & 0.05 & 1308 & 0.1 & 3557 & $n m$ & $n m$ & $\mathrm{nmm}$ & $86 ?$ & $n m$ & 5491 & 0.0011 \\
\hline mean & 1357 & 0.060 & 991 & 950 & 1850 & 1590 & 490 & 11.6 & 50.7 & 8.2 & 2463 & 0.0210 \\
\hline s & 1686 & 0.066 & 806 & 2386 & 3313 & 2053 & 636 & 16.0 & 30.0 & 10.2 & 1964 & 0.0405 \\
\hline median & 610 & 0.050 & 865 & 11 & 365 & 870 & 260 & 6.1 & 57.0 & 5.8 & 1989 & 0.0057 \\
\hline
\end{tabular}

The gold to silver $(\mathrm{Au} / \mathrm{Ag} \times 100)$ ratio in artefacts and metallurgical debris such as litharge provides a useful provenance parameter to delimit which ores were potentially exploited, as both these relatively inert metals survive the high-temperature processing operations (Gale et al. 1980; Pernicka 1981; Reedy and Reedy 1988; Meyers 2003; Wood et al. 2017b; Wood et al. 2019). The Au/Ag levels of Laurion ores (Table 3) are very low $(\mathrm{Au} / \mathrm{Ag} \times 100$ : $0.0003-0.1286$; mean $=0.0210$; median $=0.0057)$ and generally lower than those of ores on Siphnos $(\mathrm{Au} / \mathrm{Ag} \times 100$ : 0.0002-0.85; mean $=0.0897$; median $=0.0105)$, although these Siphnian ores exhibit a wide range $(\underline{T}$ able 4). Although not from the Bronze Age, Table 5 shows the Au/Ag ratios of silver from Athenian coins (c. 5th and 4th centuries BCE), generally considered to have been minted from silver mined at Laurion, and Archaic Siphnian coins (c. 6th and first half of the 5th century BCE) (Gale et al. 1980) alongside the Au/Ag ratios of galena ores from Laurion and Siphnian ores (Table 3 and Table 4). As expected, the Athenian coins generally exhibit lower Au/Ag values than Siphnian coins, in agreement with the Au/Ag values of the ores from which they are considered to have derived. The Attic Wappenmünzen coins (c. 6th century BCE) are also presented to highlight that they have much higher Au/Ag levels than found in galena ores from Laurion or Athenian coins (c. 5th and 4th centuries BCE) which, along with their LIA signatures (Figure 4), strongly indicates a different provenance. 
Table 4: Silver and gold content of ores from Ayios Sostis, Siphnos (after Muller and Gentner (1979) published in Gale et al. 1980). $s$ is standard deviation. Note that the silver values are slightly different from those in Table 2 because the current table presents the mean values of duplicate runs (adapted from

Tylecote $\underline{1987}$, table 3.9b)

\begin{tabular}{|c|c|c|c|}
\hline Siphnian ores: Ore Number & $\mathrm{Ag}(p p m)$ & Au (ppm) & $\mathrm{Au} / \mathrm{Ag} \times 100$ \\
\hline TG43-36.1 & 1890 & 0.11 & 0.0058 \\
\hline TG43-36.2 & 86 & 0.01 & 0.0116 \\
\hline TG43-36.3 & 2530 & 0.07 & 0.0028 \\
\hline TG43-9 & 3940 & 0.04 & 0.0010 \\
\hline TG43-10 & 3010 & 0.19 & 0.0063 \\
\hline TG43-11 & 200 & 1.7 & 0.85 \\
\hline TG43-13 & 670 & 0.19 & 0.0284 \\
\hline TG43-15 & 5.8 & 0.005 & 0.0862 \\
\hline TG43-16 & 62 & 0.03 & 0.0484 \\
\hline TG43-19 & 4490 & 1.2 & 0.0267 \\
\hline
\end{tabular}




\begin{tabular}{|c|c|c|c|}
\hline TG43-20 & 1490 & 0.14 & 0.0094 \\
\hline TG43-22 & 1680 & 0.04 & 0.0002 \\
\hline mean & 1671 & 0.31 & 0.0897 \\
\hline $\mathbf{S}$ & 1559 & 0.55 & 0.2407 \\
\hline median & 1585 & 0.09 & 0.0105 \\
\hline
\end{tabular}

Few analyses of Bronze Age silver objects exist and even fewer that record both LIA and compositional data (Data section, Table 9). Figure $\underline{9}$ shows LIA plots of Bronze Age silver objects from Crete, other Greek islands and the Greek mainland (data from OXALID (2020) shown in Table 9). It is immediately apparent that very few silver objects are consistent with the Siphnian ore field. Essentially, all of the Cretan silver appears to be consistent with the Laurion LIA ore field. Most of the silver from other Greek islands is consistent with either Laurion or Siphnian ores and most of the Greek mainland silver objects appear to map either within or close to the Laurion or Siphnian ore fields, with at least one case falling well outside both of these fields. Interestingly, the silver objects from the Greek islands that appear to fall within the Siphnian ore field (Figure 9) are from the Early Bronze Age (from Amorgos ECI (late) and from Syros ECII). This could suggest that these silver objects derived from Siphnian silver deposits and were extracted with Siphnian lead before being transported to these islands at an early date when lead was still available on Siphnos to make lead objects (Figure 8). Alternatively, it could suggest that Siphnian lead (or lead from a deposit with a LIA signature similar to Siphnos) was used to extract silver from disseminated silver-bearing ores from other locations, perhaps on Amorgos and Syros. Since some of the most notable finds of silver and lead artefacts have been made on Amorgos, Syros and Naxos (Branigan 1968), this explanation cannot be ruled out. More recently, excavations at EBA sites on the islands of Dhaskalio and Kavos, have recovered silver, lead and litharge (with litharge LIA signatures mapping to Laurion and Siphnos), which indicate lead and silver metallurgy was practised (Georgakopoulou 2018, 501-32). 
Table 5: Au/Ag $\times 100$ of Laurion and Siphnian ores and Athenian and Siphnian coins (for data sources see $\underline{\text { Table } 3}$ and $\underline{\text { Table } 4}$ and Figure 4). Values of the mean, standard deviation, median and ranges are shown. $\mathrm{n}$ denotes the number of samples measured. Athenian coins generally exhibit lower Au/Ag values than

Siphnian coins, in agreement with the Au/Ag values of the ores from which they are considered to have derived. The Au/Ag $\times 100$ of Wappenmünzen coins and the LIA values plotted in Figure 4 support that the silver was not from the galena ores of Laurion

\section{$\mathrm{Au} / \mathrm{Ag} \times 100$}

Siphnian ores $(n=12)$

Archaic Siphnian coins $(n=12)$

Laurion ores $(n=16)$

Archaic Athenian coins $(n=21)$

Wappenmünzen coins $(n=7)$
Mean (standard deviation)

$0.0897(0.2407)$

$0.26(0.22)$

$0.0210(0.0405)$

$0.0519(0.085)$

$0.2635(0.3082)$
Median

0.0105

0.0057
$0.0003-0.1286$

Range

$0.0002-0.85$

$0.02-0.62$

At first, Figure 9 would seem to support the proposition that Laurion was the predominant silver source in the Bronze Age Aegean, with Siphnos also supplying some silver (or a few silver objects) to the Greek islands. In fact, this line of reasoning fits well with the aforementioned narratives that Minoan metallurgy depended on metals imported through intensive seaborne networks associated with Laurion and the Greek islands (see Section 2). However, the low numbers of silver objects with a Siphnian LIA signature is surprising for an island that was a silver producer from the Bronze Age until the 5th century BCE, unless lead from Laurion was used to extract the silver from the silver-bearing ores on Siphnos, resulting in the transfer of the Laurion LIA signature to the Siphnian silver.

We therefore suggest that some silver objects that fall within the Laurion LIA field were made with silver extracted using lead from Laurion but were not necessarily made from silver that derived from Laurion. 
To some degree, this hypothesis is already supported by the variation in LIA signatures of the silver objects in Figure 9 (i.e. the spread in the data suggests multiple sources rather than a specific area being exploited). Essentially, unlike a system in which both silver and lead derive from one source (such as argentiferous galena from Laurion - see the Athenian coins in Figure 4), a system that derives its lead and silver from different geological locations, by definition, would be a mixed system and therefore exhibit more variation owing to the mixing of isotopic signatures (Wood et al. 2019; Wood and Montero-Ruiz 2019).

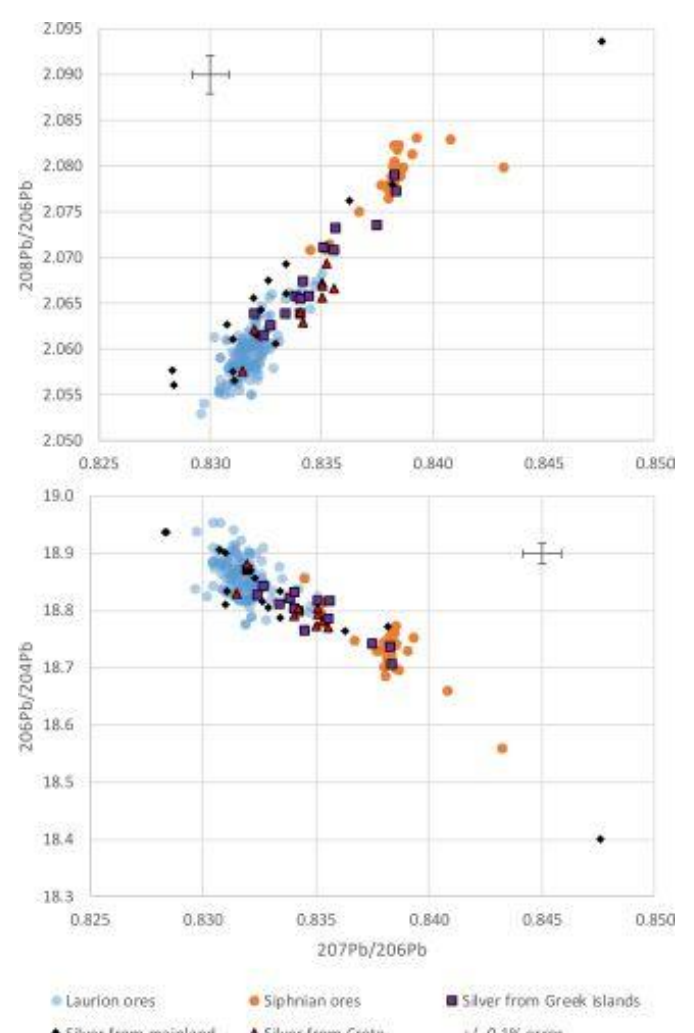

Figure 9: LIA mirror plot of silver objects (OXALID 2020) found on the Greek mainland (Laconia, Messenia and the Argolid, in the Peloponnese, and Perati near Laurion) and Crete and other Greek islands (Amorgos and Syros in the Cyclades, Kos in the Dodecanese and Euboea). Note that three silver objects consistent with the Siphnian ore field are from the Early Bronze Age, which could suggest that the silver was extracted using Siphnian lead. Although the silver may have derived from Siphnos, it could have come from silver- 
bearing ores elsewhere - possibly from the islands on which the objects were recovered, i.e. Amorgos and Syros. Note the spread in the LIA values of silver, which could suggest mixed isotopic signatures, i.e. lead from one source, silver from another

The $\mathrm{Au} / \mathrm{Ag}$ ratio should be maintained from the ore, through the processing, to the object. Based on compositional observations, the silver artefacts in Figure 9 with higher $\mathrm{Au} / \mathrm{Ag} \times 100$ values probably do not derive from the argentiferous galena ores at Laurion. In fact, as mentioned above, the variability in gold concentrations in silver has been used to differentiate between generic lead-silver ore types (Meyers 2003) (Figure 2), with an empirical value of $0.1 \mathrm{wt} \% \mathrm{Au}$ in silver objects being the upper limit for silver derived from galena (Gale et al. 1980; Meyers 2003; Butcher and Ponting 2014, 102).

Examining the silver objects with compositional data in Figure 9, two out of five objects recovered at Amorgos (ECII) in the Cyclades that were above the detection limits of the X-ray fluorescence (XRF) technique, have Au/Ag $\times 100$ levels of 0.1 and 0.2 (OXALID $\underline{2020}$ ) even though both samples fall within the Laurion LIA ore field. Furthermore, two objects from the Psychro cave on Crete and one sample from Thessaly have Au/Ag $\times 100$ levels of $0.2,2.6$ and 1.2, respectively. Of the nine objects from Greece examined by XRF (OXALID 2020), five have Au/Ag levels in excess of that usually associated with galena (i.e. $>0.1 \mathrm{wt} \% \mathrm{Au}$ ). This would appear to discount argentiferous lead ores (at Laurion and elsewhere) as the silver source for these objects.

Although it is difficult to generalise from such a small sample, these compositional limits would support the proposition that some of these nine objects were manufactured from silver that had not been extracted from galena nor from native silver (which can have low gold levels in the region of $0.01 \mathrm{wt} \% \mathrm{Au}$ - Patterson 1971) but from large silver minerals such as cerargyrite and argentite, as 'they can be auriferous, yielding perhaps up to 0.5 per cent of gold in the silver obtained from them' (Gale and Stos-Gale $1981 \mathrm{c}, 108$ ) or up to 1wt\%Au (Patterson 1971). Geological surveys at Laurion have identified ore shoots exceptionally rich in gold in the oxidised zones (Voudouris and Economou-Eliopoulos 2003; Voudouris 2005, 1089-1092; Voudouris et al. 2008) and, as mentioned above, some islands, such as Melos, have gold dispersed in quartz veins associated with silver deposits (Kilias et al. 2001). This could suggest that some of the silver objects in Figure 9 may have been smelted from dry silver ores associated with gold.

\subsection{Lead levels in silver objects}

Silver with low levels of lead would support the proposition that argentiferous lead ores were not exploited in the Bronze Age, as argentiferous lead ores require cupellation. Furthermore, it would suggest that silver minerals were still being exploited, i.e. minerals that could be smelted for their silver under a cover of charcoal without adding lead. 
At this point it is perhaps necessary to examine some of the misconceptions about the presence of lead in silver. First, some techniques that have been used to measure compositions of lead in silver artefacts are problematic for this purpose, such as neutron activation analysis (NAA) (Scott 2010, 27). Furthermore, lead is not always distributed homogeneously in silver (Wood and Montero-Ruiz 2019), making it difficult to compare studies that have measured lead concentrations over different sample areas. Nonetheless, it is not contentious to say that the cupellation process will result in residual lead in the silver.

Craddock $(1995,213 ; 2014)$ has suggested that lead levels below $0.05 w t \% \mathrm{~Pb}$ in silver artefacts are indicative of silver extracted from ores without the need for cupellation. For example, native silver has low levels of lead $(<0.01 \mathrm{wt} \% \mathrm{~Pb}-\mathrm{Patterson} 1971 ; 0.02-0.05 \mathrm{wt} \% \mathrm{~Pb}-$ Bartelheim et al. 2012), which led to the suggestion that silver artefacts of the Early Bronze Age Argaric culture in Iberia (second millennium $\mathrm{BCE})$, which have low levels of lead $(\approx 0.05 \mathrm{wt} \% \mathrm{~Pb})$, are likely to have been smelted directly from native silver and/or silver ores (Bartelheim et al. 2012; Wood et al. 2019).

Craddock's $(1995,213 ; 2014)$ empirical threshold of $0.05 w t \% \mathrm{~Pb}$ was presumably determined from examining silver or silver artefacts of known origin. This would require making assumptions regarding the processes that had been carried out, but should not include compositional data to support these assumptions in order to avoid circular arguments. Silver from silver minerals, for example, can be associated with lead. Cerargyrite $(\mathrm{AgCl})$ can have up to $2.5 \mathrm{wt} \% \mathrm{~Pb}$ (Gale and Stos-Gale 1981a) or up to 10wt\%Pb (Patterson 1971, 304, 315). This would suggest that appreciable levels of lead in a silver object could have derived from a silver ore that was smelted under a cover of charcoal (i.e. without exogenous lead), or because it had undergone cupellation.

Despite this issue, some researchers have advocated for lead ores as the source of ancient silver, presumably on the basis of their relative abundance. For example, the 13 analyses $(n=13)$ conducted on the silver boat-shaped lyre with the stag $(c .2450$ BCE) (sample: 30-12-253 in Hauptmann et al. 2018, table 2) from the Royal tombs at Ur in Mesopotamia have been interpreted as a signature of the silver deriving from argentiferous lead ores (and had therefore undergone cupellation) because the lead concentrations were significant $(\mathrm{Pb} \%$ : mean $=0.13$; standard deviation $(s)=0.21$; median $=0.10 ;$ range: $0-0.7 ; n=13$ ). Admittedly, these levels would appear to discount native silver sources. However, this silver could have derived from dry silver ores. In fact, large mineralisations of horn silver or argentite chipped out of polymetallic host rocks would be perhaps a more likely source for this artefact because zinc concentrations are quite high $(\mathrm{Zn} \%$ : mean $=1.34 ; \mathrm{s}=1.63$; median = 0.6; range: $0.2-5.6 ; n=13)$. In effect, the presence of volatile zinc, potentially from sphalerite $(\mathrm{ZnS})$, is not consistent with the high temperature processes associated with the extraction of silver from argentiferous lead ores, which would oxidise and/or concentrate in the litharge (Gale et al. 1980; Stos-Gale and Gale 1982).

Other EBA artefacts have appreciable levels of zinc and significant levels of lead (Meyers $\underline{2003}$ ) (Table 6). For example, two silver ingots recovered from the third millennium BCE context of Mahmatlat in Anatolia, now in the Museum of Anatolian Civilisations in Ankara (AAN406, AAN407), have significant concentrations of zinc (6.22wt \% and $13.1 \mathrm{wt} \%)$ and lead $(0.21 \mathrm{wt} \%$ and $0.15 \mathrm{wt} \%)$. Furthermore, a 
silver relief bowl (AAN007) from Alaca Höyük (third millennium BCE) and silver from Troy II (mid-third millennium BCE), which includes beads, a coil bracelet and an earring, have appreciable levels of zinc and lead. In effect, levels of lead in silver that is strongly suspected not to have undergone cupellation (owing to the presence of zinc) can reach a few tenths of a percent.

Table 6: Early Bronze Age silver from Anatolia (adapted from Meyers 2003). Note that zinc is present in appreciable concentrations and levels of lead are generally in the tenths of per cent. The Au/Ag ratios for this EBA silver are generally much higher than those found in silver derived from galena, which has values of $\mathrm{Au} / \mathrm{Ag} \times 100<0.1$

\begin{tabular}{|c|c|c|c|c|}
\hline Sites in Anatolia & EBA Chronologies & Zn\% & $\mathrm{Pb} \%$ & $\mathrm{Au} / \mathrm{Ag} \times \mathbf{1 0 0}$ \\
\hline Mahmatlat & 3rd millennium BCE & 6.22 & 0.21 & 0.02 \\
\hline Mahmatlat & 3rd millennium BCE & 13.10 & 0.15 & 0.10 \\
\hline Alaca Höyük & 3rd millennium BCE & 0.18 & 0.15 & 0.34 \\
\hline Troy II & mid-3rd millennium BCE & 0.90 & $<0.08$ & 4.76 \\
\hline Troy II & mid-3rd millennium BCE & 1.27 & 0.17 & 0.45 \\
\hline Troy II & mid-3rd millennium BCE & 2.15 & 0.33 & 0.68 \\
\hline Troy II & mid-3rd millennium BCE & 3.6 & 0.41 & 0.70 \\
\hline
\end{tabular}

A further strand of evidence that should also be noted is that cupellation experiments conducted by McKerrell and Stevenson (1972) demonstrate that lead remains at levels of $0.5-1 \mathrm{wt} \% \mathrm{~Pb}$ in silver. Examples of potentially cupelled silver in the archaeological record show that 'Orientalising' silver objects in Iberia (8th-6th centuries BCE) have lead levels that are at least an order of magnitude higher 
than the earlier Argaric silver (Montero-Ruiz et al. 2008; Wood et al. 2019). Furthermore, later Egyptian silver objects have appreciable levels of lead, such as an Egyptian vase (300-200 BCE) analysed by Wanhill et al. (1998), i.e. 0.7wt\%Pb, compared to the low levels (often below the detection limits) found in pre-dynastic to New Kingdom silver (Mishara and Meyers 1974, 29-45; Gale and StosGale 1981c; OXALID 2020). In fact, it is quite telling that these increases in lead concentrations in later Egyptian and Iberian silver directly contravene expected improvements in technological processes in later periods. This already implies that different technologies to acquire silver had been employed between early and later chronologies in both Egypt and lberia.

Wanhill (2003) collected data from 124 silver objects and coins with over 95wt\% silver (e.g. Asyut hoard c. 475 BCE, which includes the coins in Figure 4) and found that lead concentrations ranged between trace levels (i.e. predominantly the ancient Egyptian silver) and $1.5 \mathrm{wt} \% \mathrm{~Pb}$, with five samples over $2 \mathrm{wt} \% \mathrm{~Pb}$, giving a mean value of $0.4 \mathrm{wt} \% \mathrm{~Pb}$. Since the silver from coins almost certainly derived from cupelled silver, this demonstrates that levels of lead in the tenths of a per cent (or much higher) can be considered a signature of silver having undergone cupellation. More significantly, however, is that these observations tend to show that lead concentrations in cupelled silver exhibit high variation, presumably as a consequence of differences in the skills and technological materials available to the craftworkers conducting the cupellation operations. For example, Gitler et al. (2008) noted high variation in the lead concentrations in southern Palestinian coins of the Persian period ( $\mathrm{Pb} \%$ : mean $=1.38, \mathrm{~s}=0.82$, median $=1.38$, range: $0.19-2.8, \mathrm{n}=25)$ and in Athenian Tetradrachms from Tel Mikhal, Israel (Gitler et al. 2009) (Pb\%: mean = 1.18, $\mathrm{s}=0.69$, median = 1.06, range: 0.41-2.57, $\mathrm{n}=11$ ). These coins had only trace levels of zinc, suggesting strongly that cupellation had been conducted, and were measured using inductively coupled plasma atomic emission spectrometry (ICP-AES), thereby removing variation due to surface effects and inhomogeneity.

In summary, silver that has undergone cupellation exhibits high levels of variation in the lead concentrations, ranging from tenths of a per cent to several per cent, probably reflecting differences in how well the process was conducted. In contrast, silver from silver ores that had not undergone cupellation would appear to vary between essentially zero and a few tenths of a per cent of lead, potentially reflecting the geological variation of lead in these individual silver sources. This would suggest that levels of lead in silver below a few tenths of a per cent had probably not been cupellated. This is much higher than the threshold of $0.05 \mathrm{wt} \% \mathrm{~Pb}$ in silver (Craddock 1995, 213; 2014), which was potentially proposed because early silver, such as ancient Egyptian silver (Gale and Stos-Gale 1981C; OXALID 2020), was presumed to have been extracted from argentiferous lead ores.

\subsection{Technological limits of silver extraction from lead}

The technical and/or economic feasibility of exploiting silver from certain ores has been determined from the silver concentrations in lead artefacts in the archaeological record (e.g. Gale and Stos-Gale 1981a; Rehren and Prange 1998). These concentrations have been assumed to represent the lower limit for silver extraction with different periods having different limits: Early Cycladic I and II artefacts 
suggested $700-800 \mathrm{~g}$ of silver per tonne of lead (i.e. 700-800ppm) while the MBA and LBA objects suggested that silver levels of 400 $600 \mathrm{ppm}$ in lead were feasible to extract. In the 6th-4th centuries BCE, it appears levels as low as 200ppm were considered viable (Gale and Stos-Gale 1981a). This presents an interesting scenario for the lead metal recovered at Habuba Kabira in North Syria (Pernicka et al. 1998), a site that has been identified as a possible location for the origin of cupellation $\left({ }^{14} \mathrm{C}\right.$ dating determined a late Uruk period date of around 3300 BCE - Pernicka et al. 1998). Here and in East Anatolia (Hess et al. 1998), both sites from the second half of the fourth millennium BCE, finds of lead smelting slag and litharge were used to support the early exploitation of lead ores for silver. However, lead metal recovered at Habuba Kabira has a silver concentration of 232ppm, which would suggest that the lead was probably not used for its intrinsic silver. In fact, the low level of silver in this lead is more indicative of its application as a silver collector for other types of silverbearing ore. Moreover, the hazelnut-sized slag from Fatmali-Kalecik in East Anatolia not only looks similar to that found at Siphnos (Figure 7) but also has silver-metal inclusions (Hess et al. 1998, fig. 5) with Au/Ag $\times 100$ of 1.26. This does not suggest the smelting of argentiferous lead ores to argentiferous lead, but rather the reduction of silver minerals to silver in the presence of lead.

It should also be noted that lead sheet in the graves in the Royal Tombs of Ur (c. 2450 BCE) was not de-silvered (Forbes 1950, 193) and a lead tumbler had 700ppm of silver in the lead metal (Plenderleith 1934, 295). Another cup from these tombs has comparable levels of silver (500ppm) (Klein and Hauptmann 2016). Furthermore, Spartan lead votive figures (700-500 BCE) had 0.057wt\% silver (570ppm) (Friend and Thorneycroft 1929, 105-17). This would support the proposition that lead was not necessarily used for its intrinsic silver as late as the Archaic/Classical period.

Technological limits have other repercussions. The premise behind exploiting argentiferous lead ores would suggest that, if the silver concentrations were high, the smelted lead was used for silver and subsequently cupellated; if it was low, it was used to make lead objects. Figure 10 shows a histogram for the concentration of silver in 267 Bronze Age lead artefacts from the Aegean, taken from the data presented on the OXALID database (2020) and Pernicka et al. (1983). The upper level of silver in these lead objects is generally under $0.1 \mathrm{wt} \% \mathrm{Ag}(1000 \mathrm{ppm})$, with an average about $0.05 \mathrm{wt} \% \mathrm{Ag}(500 \mathrm{ppm})$. Furthermore, as many of these lead objects also have gold to silver levels $(\mathrm{Au} / \mathrm{Ag} \times 100$ : mean $=0.055 ; \mathrm{s}=0.231$; median $=0.015, \mathrm{n}=267)$ and LIA values consistent with Laurion ores (see Table 3 and Figure 11, Figure 12 and Figure 13), this was used to postulate that the lead ores at Laurion were exploited in the Bronze Age. For example, lead objects recovered from the Late Helladic site at Perati (about 40km from Laurion) have LIA signatures and gold levels that suggest the lead derived from Laurion $(\mathrm{Au} / \mathrm{Ag} \times 100$ : mean $=0.0059, \mathrm{~s}=0.0020$; median $=0.0064$; range 0.0024-0.0077, $\mathrm{n}=7)(\mathrm{Stos}-$ Gale and Gale 1982, table 6). Similarly, although not from the Bronze Age contexts, the percentage of gold in silver in lead objects from Thorikos, Megala Pevka and Merkati (sites nearby the Laurion mines) range from 0.008-0.055wt\%Au (Gale et al. 1980, 33, table 11). This line of argument, however, only supports the proposition that lead was exploited at Laurion. It does not necessarily imply the same for silver. 


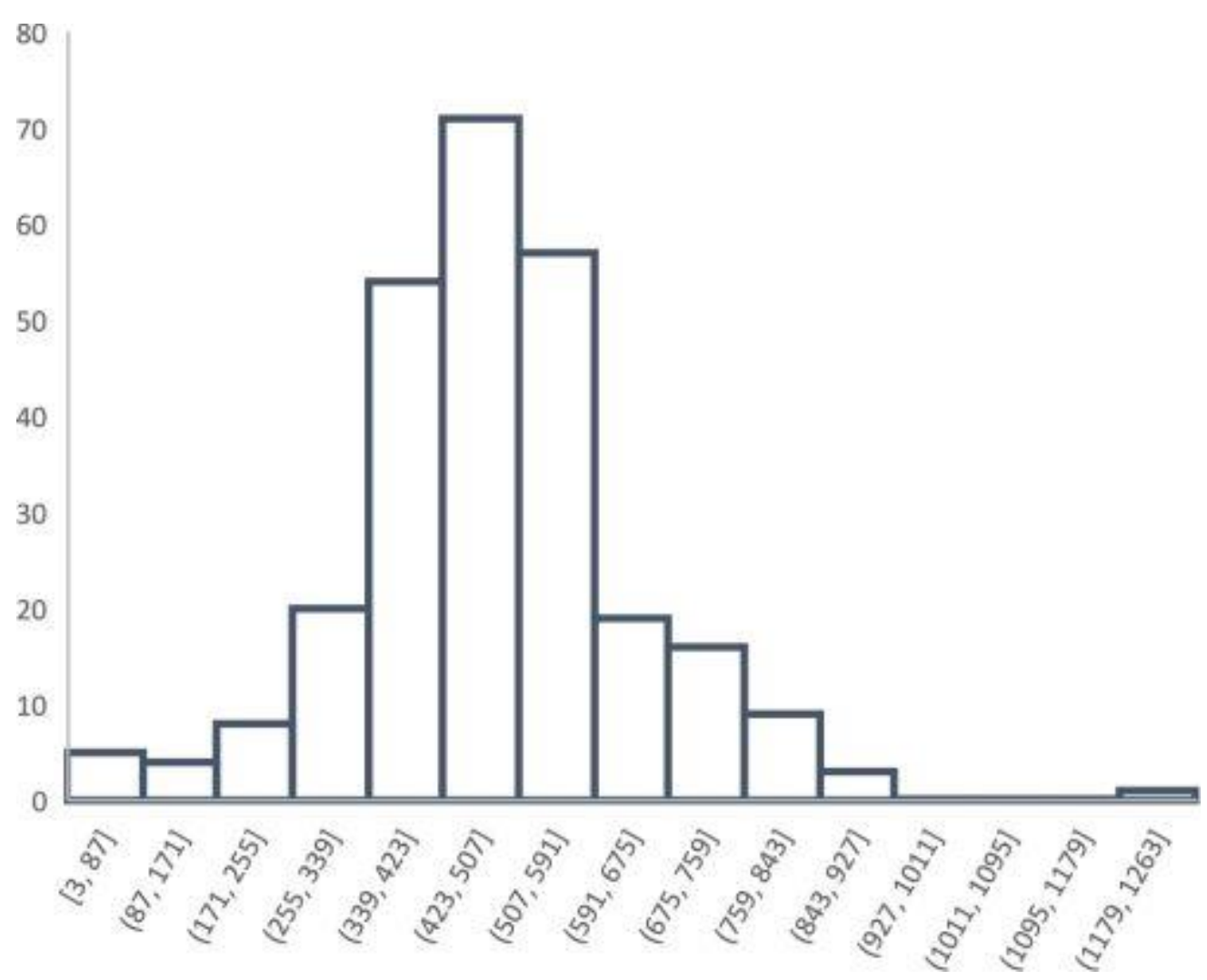

Figure 10: Histogram of the silver content (ppm) in 267 Bronze Age lead artefacts recovered around the Aegean (data from OXALID 2020). For example, about 70 lead objects have concentrations of silver between 423 and 507ppm in the lead. The distribution shows no evidence of bimodality, which would suggest a remarkably efficient separation process if lead (ores or metal) was being selected for either lead or silver objects on the basis of its silver content. Alternatively, it may suggest that lead ores with higher levels of silver had yet to be discovered and/or exploited

Nonetheless, there is evidence of cupellation (or at least litharge) at a number of Bronze Age sites across the ancient world, including Laurion, on some of the Greek islands and further afield (e.g. Thasos, Anatolia, North Syria, Iran), which has been used as evidence that silver was produced by smelting argentiferous lead ores. The fact that some lead ores from Laurion have silver concentrations of over 500 ppm (i.e. concentrations that are not generally found in lead objects), led to the suggestion that ores were selected in the Bronze Age 
based on whether they were found to be silver or lead-bearing (Gale and Stos-Gale 1981a; Stos-Gale and Gale 1982). The distribution in Figure 10, however, suggests that such a procedure must have been remarkably efficient, as there appears to be only a single peak (i.e. there is no evidence of bimodality in the distribution). In fact, the absence of a peak at high concentrations of silver raises the question of how the technical limits of silver extraction discussed above were ever established. Essentially, a single-peaked distribution for silver impurities in lead objects would imply that all lead with levels of silver above an average of around 500ppm was used to make silver objects. This may have been the case, in that Figure 10 could suggest that a particular deposit was selected for lead, possibly determined by performing a test smelt on a deposit and cupellating the lead produced, or as a test cupellation on a batch of lead. In fact, this scenario was proposed by Gale and Stos-Gale (1981a, 217). However, without any evidence of a bimodal distribution, the low levels of silver found in lead objects could also suggest that deposits with higher levels of silver had yet to be discovered or exploited, such as those that were later used for Athenian coins. In effect, the distribution of silver found in Aegean Bronze Age lead objects in Figure 10 is more indicative of Laurion lead ores being exploited solely for lead.

Another question that needs to be addressed is, exactly what was transported from Laurion? Even if one accepts that smelted lead could have been divided into lead and silver-bearing categories (a difficult task when silver is at trace levels), it is unlikely that argentiferous lead would have been transported from Laurion for secondary processing elsewhere. It should be noted that Gale and Stos-Gale (1981a 213-23) advocate for lead being transported to Akrotiri, based on the fact that there was no lead smelting slag but litharge with a Laurion LIA signature was recovered. Others have suggested that ores were transported (e.g. Forsyth 1997).

Both of these scenarios, however, seem unlikely primarily because of weight and bulk: the level of silver in even the most silver-rich Laurion ores (i.e. Table 3: 4760ppm of $\mathrm{Ag}$ in the predominantly galena ore, thereby producing approximately 5920ppm of Ag in the smelted lead metal) would require at least $210 \mathrm{~kg}$ of argentiferous ores or $169 \mathrm{~kg}$ of smelted lead to be transported to produce $1 \mathrm{~kg}$ of silver. Clearly, more ore or lead would have had to be transported to produce this amount of silver from less argentiferous deposits (or deposits with more gangue minerals). This would be a very inefficient procedure and although litharge with a Laurion signature has been recovered on Greek islands such as Crete and Kea (see below), this is difficult to reconcile with the exploitation and transportation of Laurion lead or galena ores for the intrinsic silver.

\subsection{Lead objects and litharge}

Figure 11 shows LIA mirror plots of lead and litharge found on Kea and Crete, respectively. Lead artefacts found on Kea appear to have derived from Laurion, Siphnos and possibly other locations. Litharge recovered on Kea seems generally consistent with Laurion. Most Cretan lead objects appear to derive from Laurion; some fall within the Siphnian LIA ore field and several fall between the two LIA fields. Litharge recovered on Crete is consistent with both Laurion and Siphnos. It should be recalled that silver found on Crete lies 
predominantly within the Laurion ore field (Figure 9), which would indicate that the silver associated with the Cretan litharge with a Siphnian LIA signature has yet to be identified in the archaeological record.
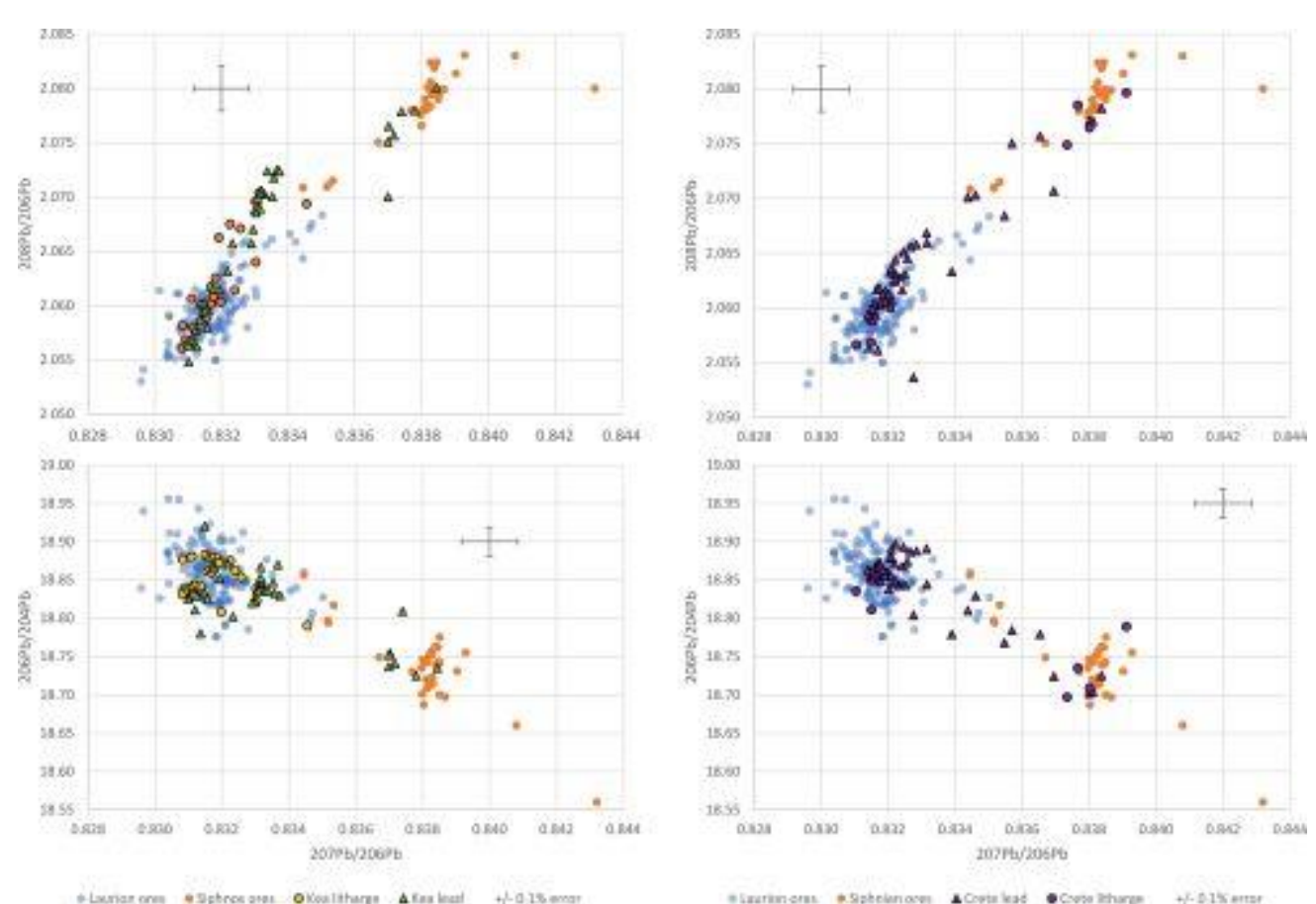

Figure 11: LIA mirror plots for lead and litharge on Kea and Crete. (left mirror plots) Lead objects and litharge found on Kea are presented with Laurion and Siphnian ores. Lead objects found on Kea are consistent with Laurion and Siphnos. Litharge recovered on Kea appears to be consistent with Laurion. A group of litharge and lead samples may be present at ${ }^{207} \mathrm{~Pb} / 206 \mathrm{~Pb} \approx 0.833$. This could indicate a further source in addition to Siphnos and Laurion signatures, or possibly mixed lead from Laurion and Siphnian sources. (right mirror plots) Litharge and lead objects recovered on Crete are consistent with both Siphnian and Laurion ores. Some lead objects fall between these two ore fields, which could suggest mixed LIA signatures, i.e. lead from both sources was mixed together. Alternatively, it could suggest that lead derived from another source, e.g. lead from one of the islands, such as Crete. Data from OXALID (2020)

As with the lead and litharge with a Siphnian signature (Figure 11), which would suggest that Siphnian lead was not only being used to make objects that ended up on the Greek islands (e.g. the Naxian lead boat models referred to earlier) but also to extract silver, the 
presence of litharge and lead with a Laurion signature recovered on Kea and Crete could support that lead from Laurion was carried by prospectors to use when they encountered dry silver ores, i.e. silver ores that required grinding and mixing with molten lead prior to cupellation. In other words, these finds might suggest that Laurion lead was used to extract silver from dry silver ores on Kea and Crete.

This is not a new proposition. In fact, Branigan (1968) recognised the possibility that the Minoans utilised their own sources of silver and lead, and Strong (1966) states that local sources of silver may have been used in the Cyclades because of high concentrations of gold and copper in the silver. Moreover, Davis (1977) identified some of the Mycenaean shaft-grave silver objects as Minoan. These objects have been interpreted as either:

i. made by Minoan craftsmen at Mycenae with Laurion silver; or

ii. made on Crete from silver imported from Laurion with the finished articles being sent back to mainland Greece.

Perhaps a less convoluted alternative to both of these options would be that the objects were made on Crete by Minoan craftsmen from Cretan silver that had been extracted using Laurion lead, i.e. the same lead used to make the lead objects that have been recovered on Crete. The same rationale can be applied to Kea, an island that has been considered to have its own silver sources (Caskey et al. $\underline{1988)}$.

Table 7 shows the Au/Ag ratios for litharge found on Kea, and lead recovered on Kea and from elsewhere in the Aegean. The fact that the $\mathrm{Au} / \mathrm{Ag}$ levels of the litharge recovered on Kea ( $\mathrm{Au} / \mathrm{Ag} \times 100$ : mean $=0.414 ; \mathrm{s}=0.777$; median $=0.035 ;$ range: $0-2.933 ; n=19)$ are much higher than the Au/Ag levels from Laurion ores, lead objects recovered near Laurion, lead objects recovered on Kea or the averages of 267 lead objects recovered at the Bronze Age sites around the Aegean (the Argolid, Attica, Crete, Amorgos, Antiparos, Melos, Naxos, Paros, Thera, and Kea) (Table 7), suggests strongly that the litharge on Kea was produced by extracting silver from a mineral with a higher Au/Ag level than the lead used to extract it. This would suggest that the component that contained the silver was richer in gold, thereby explaining the higher $\mathrm{Au} / \mathrm{Ag}$ ratio of any silver prills entrapped in the litharge compared to the Au/Ag ratios of available lead. This is support for the silver being extracted from dry silver ores (i.e. cerargyrite has gold levels that can reach 1 wt\%Au Patterson 1971), perhaps using a similar process to that proposed for the ores on Siphnos.

Table 7: Mean and standard deviation of $\mathrm{Au} / \mathrm{Ag} \times 100$ levels in litharge and lead recovered on Kea. Median values and ranges are also shown. Lead objects found at Perati on Attica and Bronze Age lead objects recovered from around the Aegean are also presented alongside Laurion ores. $n$ denotes the number of samples. The Au/Ag levels in the Kea litharge suggest that another component was present that had higher levels of gold than that found in association with the silver in lead ores or lead objects. Data from OXALID $\underline{2020}$ 


\begin{tabular}{|c|c|c|c|}
\hline $\mathrm{Au} / \mathrm{Ag} \times 100$ & Mean (standard deviation) & Median & Range \\
\hline Litharge on Kea ( $n=19)$ & $0.4140(0.7772)$ & 0.0345 & $0-2.933$ \\
\hline Lead objects on Kea ( $n=28)$ & $0.1672(0.6204)$ & 0.020 & $0.00427-3.3166$ \\
\hline Laurion ores ( $n=16$ ) & $0.0210(0.0405)$ & 0.0057 & $0.0003-0.1286$ \\
\hline Lead objects at Perati, Attica $(n=7)$ & $0.0059(0.0020)$ & 0.0064 & $0.0024-0.0077$ \\
\hline Aegean lead objects ( $n=267$ ) & $0.055(0.2308)$ & 0.015 & $0-3.3166$ \\
\hline
\end{tabular}

Another site that has litharge is Thorikos, located near the mines of Laurion in Attica (Figure 12). It is potentially the most well known and one of most informative sites in terms of addressing whether Laurion was exploited for silver in the Bronze Age, mainly because lead and litharge were found in association. Mussche $(1974,44-66)$, under whose direction the excavations at Thorikos were carried out, describes the context as a fairly intact private house (even the stucco covering on the threshold was intact) from the MH period (c. 20001550 BCE). The main room yielded a child's burial and two pieces of litharge. Four flat cakes of lead (which probably fell as molten metal on the beaten earth) and some slag were found in association (Servais 1967, 20-4, n. 67). A terminus post quem for the lead and litharge somewhere between 1550 and 1500 BCE was immediately recognised as being contemporary with the Mycenaean shaft grave silver. 


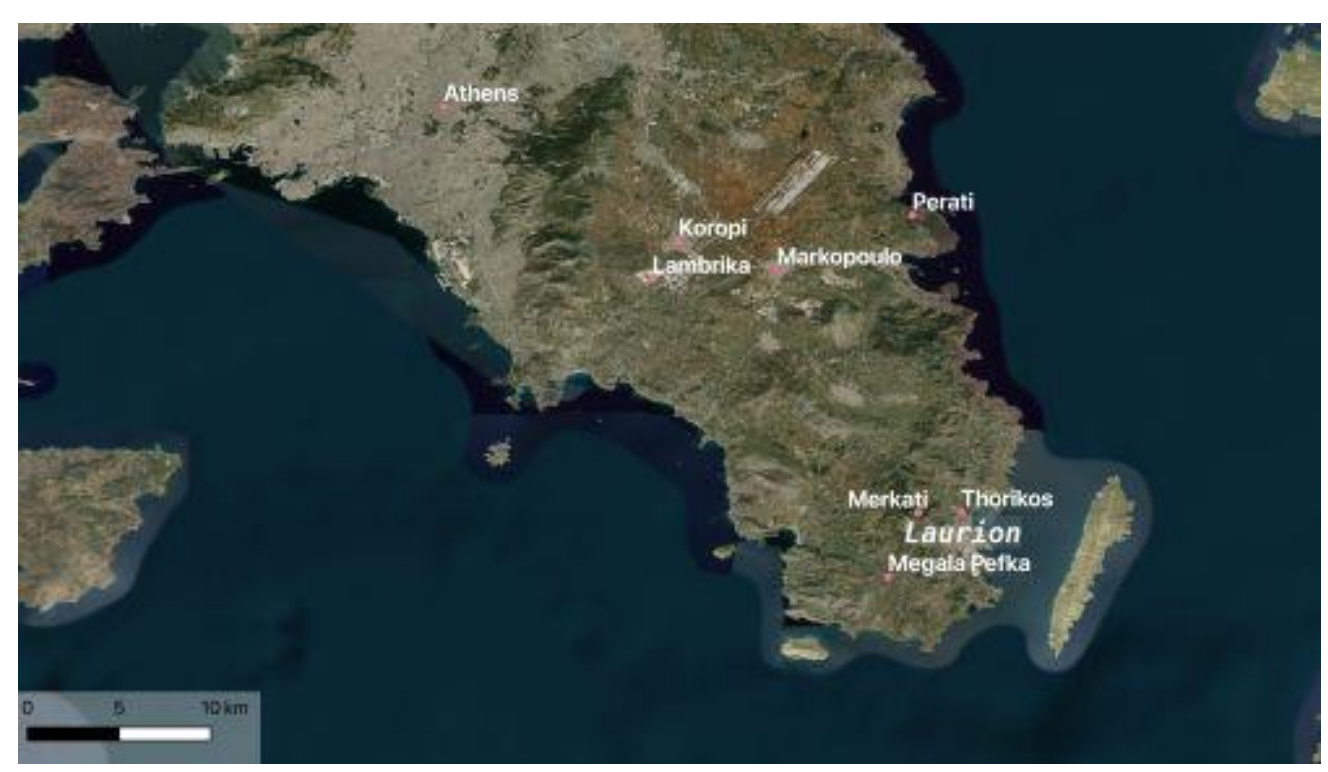

Figure 12: Map of Attica showing Laurion and sites mentioned in the text

Table 8 shows the LIA values and the calculated $\mathrm{Pb}$ crustal ages of lead (see Table 10 and below) and litharge recovered at Thorikos. The LIA values are very close to each other and commensurate with Laurion ores (as would be expected with its proximity to the Laurion mines) and Archaic Athenian coins (see Figure 4).

Compositional analyses conducted on the lead and the litharge from Thorikos provided information on the cupellation process (Table 8). Finding lead and litharge in the same context, and lead deriving from Laurion, in addition to the presence of trace levels of residual silver in the litharge, led to the conclusion that argentiferous lead ores were mined and smelted at Laurion and the argentiferous lead was cupellated to extract the silver in the house at Thorikos. Indeed, these finds were believed to prove that Laurion was being worked for silver in the Bronze Age (LHI: c. 1600 BCE) (Gale and Stos-Gale 1981a), the most flourishing period of the shaft graves at Mycenae (Dickinson 1977, 51). Interpretations focused on the relationships between Laurion silver and Mycenae (Stos-Gale and Gale 1982). 
Table 8: Lead and litharge found at a Bronze Age (Middle Helladic context) site in Thorikos, Acropolis 153cS. Analyses include one of four fragments of melted

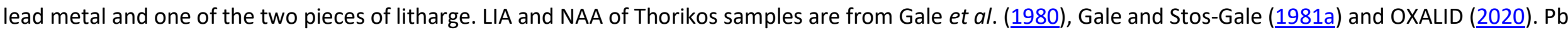
crustal ages in millions of years ( $\mathrm{Ma}$ ) were calculated from the lead isotope data using the two-stage evolution model with parameters from Desaulty et al.

$\underline{(2011)}$

\begin{tabular}{|c|c|c|c|c|c|c|c|}
\hline & ${ }^{208 \mathrm{~Pb} / 206 \mathrm{~Pb}}$ & ${ }^{207} \mathrm{~Pb} /{ }^{206} \mathrm{~Pb}$ & ${ }^{206 \mathrm{~Pb} / 204 \mathrm{~Pb}}$ & $\begin{array}{l}\text { Pb crustal } \\
\text { age (Ma) }\end{array}$ & & & \\
\hline TM65.4 Lead metal & 2.06029 & 0.83160 & 18.853 & $-16 \mathrm{Ma}$ & & & \\
\hline TM65.4 Litharge & 2.06037 & 0.83133 & 18.881 & $-14 \mathrm{Ma}$ & & & \\
\hline ppm & $\mathrm{Au}$ & $\mathrm{Cu}$ & As & Sb & Ag & Sn & $\mathrm{Au} / \mathrm{Ag} \times \mathbf{1 0 0}$ \\
\hline TM65.4 Lead metal & 0.0315 & 658 & 31 & 789 & 437 & - & 0.0072 \\
\hline TM65.4 Litharge & 0.0023 & 305-322 & $110-126$ & 35.5 & 13.9 & 246 & 0.0165 \\
\hline
\end{tabular}

Although there is very little doubt that the LIA signatures of both the lead and the litharge at Thorikos are consistent with Laurion ores, the archaeological evidence and compositional data are perhaps more ambiguous regarding the types of ores exploited. The first issue of note is that a small amount of slag was also found in association with the lead and litharge. Slag would be an unusual find if only cupellation was conducted, as slag derives from the gangue during smelting ores. The presence of slag suggests that smelting had been carried out inside the house. Furthermore, the lead found at Thorikos is not particularly argentiferous $(\mathrm{Ag}=437 \mathrm{ppm})$ and is at the lower limit for what is considered viable to extract in the LBA. In fact, it is more consistent with the concentration of silver in lead objects around the Aegean (Figure 10). Moreover, as with the Kea litharge and litharge from other islands in the Aegean (Table 7), the Au/Ag ratio at Thorikos is twice as high in the litharge than in the associated lead. This could suggest that the silver produced at Thorikos did not derive from argentiferous lead ores but from a silver-bearing ore with higher levels of gold than the lead from Laurion used to extract it. In other words, the barely argentiferous lead found at Thorikos was potentially melted in a crucible and added as a silver collector to a dry silver 
ore, with the four flat lead cakes on the floor at Thorikos probably due to spillage. The small amount of slag could have been 'knocked off' at the end of the process (as later described by Erker in his treatise).

The find locations of the metallurgical debris may also indicate that the acquisition of silver in the Bronze Age was somewhat of a cottage industry, which is not in line with the scale required for the exploitation of silver from galena. Specifically, these do not appear to be contexts that produced silver from vast amounts of argentiferous lead (bearing in mind that tonnes of galena would be required to produce a few silver objects, as well as producing large slag heaps - which have not been located). In effect, although litharge has been found in dumps, it has also been found in houses, such as the private house at Thorikos, at Ayia Irini (House A in rooms 30 and 39 ), on Crete (the 'unexplored mansion'), at Akrotiri (the West House in the room of the fisherman) and the Mousia farmhouse on Siphnos.

Although Rehren et al. (1999) have suggested that this provides evidence for the use of litharge as a medicine or pigment, it could also suggest that the process of smelting and cupellation was potentially conducted at a much smaller scale than the later industrial processes associated with the extraction of silver from galena ores. It may even have been conducted on an ad hoc basis in households when silver minerals worth exploiting were found. It should also be noted that the process of extracting silver from such silver minerals would have been considerably less noxious than exploiting large amounts of galena which, being a sulphide ore, produces sulphur dioxide $\left(\mathrm{SO}_{2}\right)$ during smelting. This consideration would almost certainly rule out such an extraction process from being conducted in a domestic context.

Perhaps the most important consideration for any Bronze Age silver prospector, however, is that the silver yield from silver minerals would have been significantly higher than from extracting silver from argentiferous lead ores. For example, pure cerargyrite is about $75 \mathrm{wt} \% \mathrm{Ag}$ and $25 \mathrm{wt} \% \mathrm{Cl}$. Even considering that this mineral may be disseminated in a host rock, it still promises higher yields than silver levels dissolved in galena of a few tenths of a per cent, at most. Without access to a large-scale industrialised process, requiring substantial infrastructure, labour and control, it is simply not worth mining and smelting argentiferous lead ores to produce argentiferous lead in order to extract the trace levels of silver by cupellation.

Even accepting that absence of evidence is not evidence of absence, the paucity of Bronze Age litharge (Gale and Stos-Gale 1981a; Kassianidou and Knapp 2005, 220) and slag (e.g. Kakavogianni et al. 2008; Papadopoulos 2008) around the Aegean and further afield (Hess et al. 1998; Pernicka et al. 1998; Nezafati and Pernicka 2012; Weeks 2013) is inconsistent with the level of production required to make the exploitation of argentiferous lead ores worthwhile. This is the case irrespective of whether the Bronze Age silver prospectors were aware of the levels of silver in these ores which, as already mentioned, are invisible to the naked eye. 


\section{Mycenaean Shaft Grave Silver}

Although very few Bronze Age silver objects have been found in the Aegean (and very few of these have been analysed to produce both LIA and compositional data - see Table 9), one assemblage has drawn a lot of attention. In the pantheon of Bronze Age silver and gold objects, those from the Mycenaean shaft graves number among the most iconic in archaeology, in particular the gold death mask

attributed erroneously by Schliemann in the 1870 s as the face of Agamemnon. The objects are extremely heterogeneous: some evoke Cretan and Cycladic origins, redeployed on the Greek Peloponnese, while others are probably from the eastern Mediterranean (Broodbank 2013, 371). We make no attempt here to investigate the typological and archaeological contexts of these objects (see Karo 1930/1933 (Grave Circle A); Mylonas $\underline{1973}$ (Tomb or Shaft Grave $\Delta$ in Grave Circle B) and Davis $\underline{1977)}$ ) but focus specifically on the subsequent scientific analyses carried out on fragments removed from the silver objects. (Author note: The samples supplied by Dr Zofia Stos-Gale were the remaining fragments used by the Oxford group to determine lead isotopes in the 1980s and our EPMA results were originally discussed in Wood 2019.)

Although over 30 silver objects were recovered from the shaft graves, excavations of later contexts at Mycenae indicate that silver was rare later in the LBA (Kelder 2016, 309-19). This evidence has been used to suggest that the Mycenaeans either had access to silver as early as Late Helladic I (the era of the shaft graves $-c$. 16th century BCE), and perhaps less so afterwards, or that silver was acquired from raids and/or from gift exchange between the rulers of Mycenae and other counterparties involved in trade around the Saronic Gulf, i.e. traders from Crete, the Cyclades and the Near East (Tartaron 2013, 236). LIA of Mycenaean and Attic silver have been used to suggest that silver was being extracted from the mines at Laurion from the (late) Middle Helladic period onwards, until at least Late Helladic IIIC (12th-11th centuries BCE) (Stos-Gale and Gale 1982; Stos-Gale and Macdonald 1991).

These early LIA studies on the shaft-grave silver from Mycenae concluded that the silver analysed from 17 silver shaft-grave vessels was generally consistent with silver extracted from ores at Laurion (five vessels), the northern Greek region of Chalkidiki (six vessels), both locations (two vessels), or neither location (one vessel). One object appears not to have been included in the analysis (SG865) while two further objects (known as the Vapheio cup with spirals SG880; Stag Vessel SG388) stood out as metals of non-Aegean origin, with suggestions of a possible Anatolian ore source. More recently, Stos-Gale (2014), applying an expanded database of LIAs and a different protocol for analysing lead isotope ratios, has suggested that of the 32 silver vessels now analysed, the majority are consistent with Au$\mathrm{Ag}$-Cu ores of the south-eastern Carpathians (Romania), with only six having a LIA signature consistent with Laurion, while two vessels (the Vapheio cup (SG880) and Stag Vessel (SG388)) have LIAs that are not fully consistent with any known deposit. Stos-Gale (2014) concludes that Mycenaean warriors may have travelled to the Carpathian mountain region, bringing back gold, tin and silver. 
To some extent, the issues surrounding the provenance of the shaft-grave silver recovered at Mycenae has been impeded by the scarcity of elemental analytical data to consider alongside the LIA. Concentrations of gold, silver and copper were measured for 14 of the 17 silver vessels (Stos-Gale and Macdonald 1991) using XRF, with three samples not analysed probably owing to corrosion. Of these 14 samples, two were classified by LIA as being consistent with silver extracted at Laurion (Stos-Gale 2014). However, both items (SG505 from shaft grave IV from grave circle A and SG9563 from grave circle B gr. delta) were shown to have high gold concentrations

(0.3wt\%Au and $13 w t \% A u$, respectively), in excess of the lead ores mined at Laurion (Table 3 ). The high gold level of the sample from the earlier grave circle B (SG9563: 72wt\%Ag, 13wt\%Au and 14wt\%Cu) was attributed to possible contamination due to gilding. For the sample from grave circle A (i.e. SG505: $96 \mathrm{wt} \% \mathrm{Ag}, 0.3 \mathrm{wt} \% \mathrm{Au}$ and $3.5 \mathrm{wt} \% \mathrm{Cu}$ ), the gold was considered to have been introduced into the silver from the argentiferous ore itself. Meanwhile, the copper was considered, quite reasonably, to be an intentional addition to improve the mechanical properties of the final objects.

Other research groups also noted that some of the silver objects recovered from the shaft graves at Mycenae had higher gold to silver ratios than the ores from which LIA had been identified as their provenance. The LBA Aegean silver objects (which included silver from the shaft graves at Mycenae) analysed by Pernicka et al. $(\underline{1983}, 294)$ using NAA had 'strikingly high gold contents around 1\%'. Most of these objects did not fall within the Laurion ore LIA field (Figure 13), thereby suggesting that these high-gold silver objects derived from other ore deposits. However, Pernicka et al. $(\underline{1983})$ noted that three of the twelve silver objects had high gold contents, despite having LIA signatures that were consistent with Laurion. More LIA data to define the Laurion ore field has been produced (OXALID 2020) since Pernicka et al. (1983) carried out these analyses. Consequently, perhaps seven of the twelve analyses conducted by Pernicka et al. (1983) on Aegean Bronze Age silver objects lie within the Laurion LIA field (i.e. sample numbers: 2810, 3013, 4919, 3109, 479, 6205, t$\Delta$ ), with all apart from two (t- $\Delta$ and 6205) having Au/Ag levels well in excess of that found in the galena ores of Laurion. Figure 13 plots Pernicka et al.'s (1983) analyses (and the associated Au/Ag $\times 100$ values next to each point) with Laurion ores (note that because ${ }^{204} \mathrm{~Pb}$ was not measured only one of the usual mirror plots is presented). 


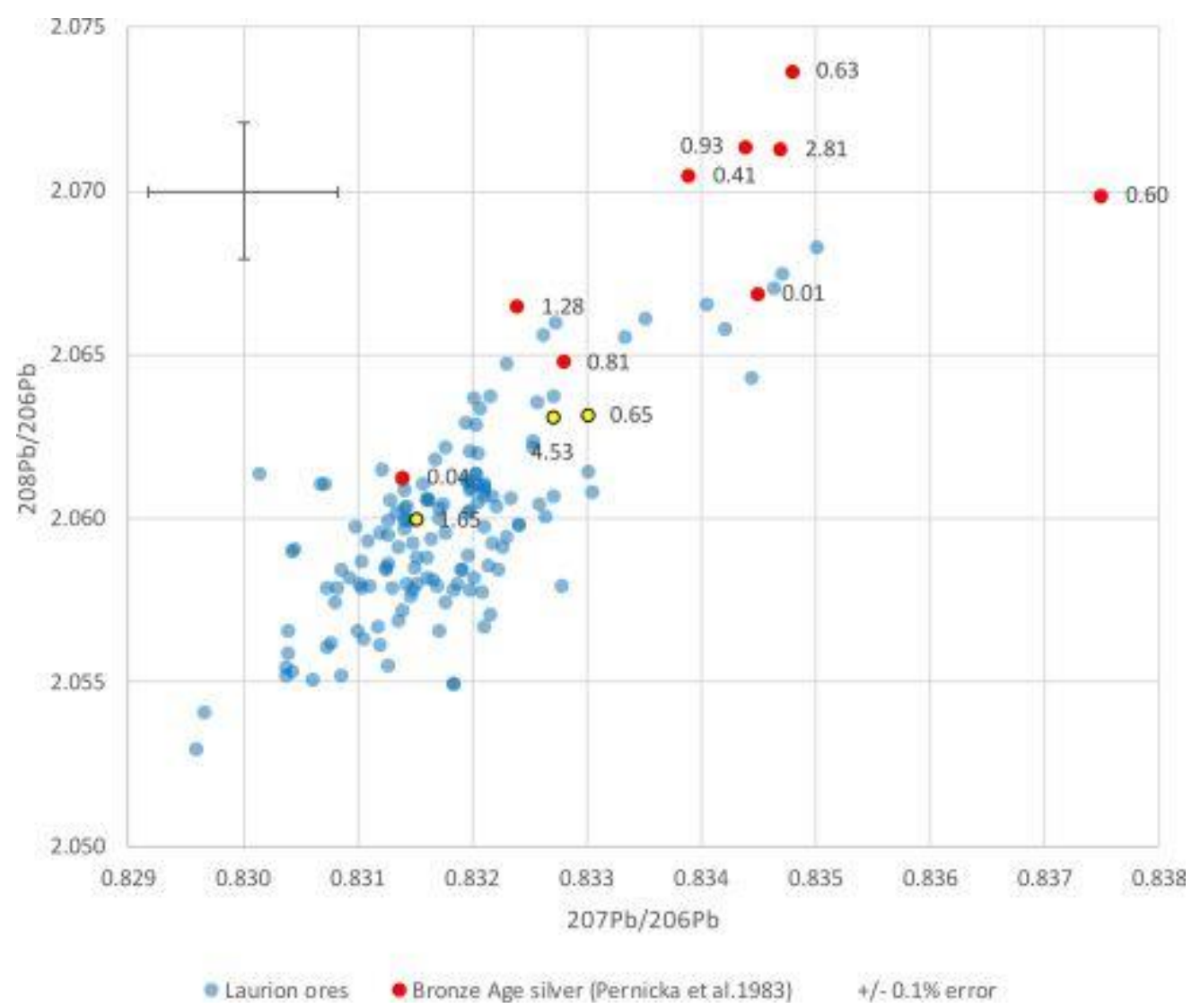

Figure 13: LIA plot for Bronze Age silver analysed by Pernicka et al. (1983) alongside Laurion ores (OXALID 2020). Ten samples are from the shaft graves at Mycenae. The three outlined yellow points show the Bronze Age silver samples identified by Pernicka as having LIA signatures consistent with Laurion but inconsistent compositional analyses. Beside each of the points are their respective Au/Ag $\times 100$ values

Recognising that the three samples (outlined yellow points in Figure 13) identified could not readily be explained, Pernicka suggested that they may have been 'purified' with Laurion lead. In other words, the anomalies with high gold, although consistent with Laurion in terms of their lead isotope signature, were considered, like the others, to have derived from ores with higher Au concentrations rather than from Laurion. 
Advocates of both isotopic and compositional approaches to this investigation searched for other silver sources that could explain the provenance of the majority of the LBA silver samples, which did not match the Laurion LIA ore field signature. Alternative silver sources, generally argentiferous lead ores (Gale and Stos-Gale 1981a; Pernicka et al. 1981), were suggested for the LBA silver objects, particularly those recovered from the shaft graves at Mycenae. As already mentioned, locations such as Anatolia, Chalkidike and Romania have been proposed (Stos-Gale 2014), as well as the Troad on the Aegean coast of north-west Anatolia (Pernicka et al. 1983) in order to explain the compositional and LIA signatures of Bronze Age silver (but not the anomalous samples mentioned above). Often guided by Classical texts in attempts to find evidence of ancient mining, these efforts were not particularly conclusive (e.g. see Pernicka et al. 1981 regarding their survey on Thasos).

\subsection{Experimental analysis}

To add to the limited corpus of compositional data for Bronze Age silver, we conducted analyses on 30 pieces of Mycenaean shaft-grave silver using an electron probe microanalyser (EPMA), including 23 silver samples from Circle A, shaft graves III, IV and V (second half of 16th century BCE (LHI)), 3 samples from Circle B, shaft grave $\Delta$ (first half of 16th century BCE (LHI) and 4 from undetermined find locations (possibly graves). The experimental and analytical protocols are presented in the data section. Our study complements and extends the previous compositional studies conducted by Pernicka et al. (1983), who conducted NAA on 12 Bronze Age silver samples (10 from Mycenae), and by Stos-Gale and MacDonald (1991) who used XRF to measure silver, gold and copper levels on 14 Mycenaean silver samples. Lead isotope measurements for these samples were previously conducted by Zofia Stos-Gale at Oxford University (StosGale 2014; Stos-Gale and MacDonald 1991). These LIA analyses are presented with Pernicka et al.'s (1983) LIA and compositional analyses in the data section (Table 11 and Table 12).

Given the date of excavation of the objects and when they were analysed, it was unsurprising that there were some sample identification issues. We have used SG numbers as identifiers here, as these were used by those who conducted the lead isotope analyses (e.g. StosGale 2014). Of course, some samples also have identifiers associated with the National Museum at Athens (NMA numbers). For example, the Siege Rhyton from Shaft Grave IV (Karo no. 481) can be identified as NMA481, but is here classified as SG481, as we wanted to differentiate the object from the analyses. The reason for wanting to differentiate is perhaps better appreciated by examining the following: SG520a and SG520b (Figure 14) have different compositional and LIA signatures (suggesting two different samples) despite being identified as NMA520 (i.e. Karo no. 520). The samples had been taken from a one-handled stemmed goblet which Davis $(\underline{1977}, 221-22$, no. 85, fig. 175) described as Minoan, comparing it with NM427 (Davis 1977, 220-21, no. 84, fig. 174), which turns out to be a gold example of the same type as Davis' no. 85. Based on this typological interpretation, Davis (1977) considered that the handle had been added at a later stage. Unfortunately, it is not known whether SG520a and SG520b are from different parts of the goblet, i.e. possibly one part from the added handle. As a result, we have treated these samples separately. 


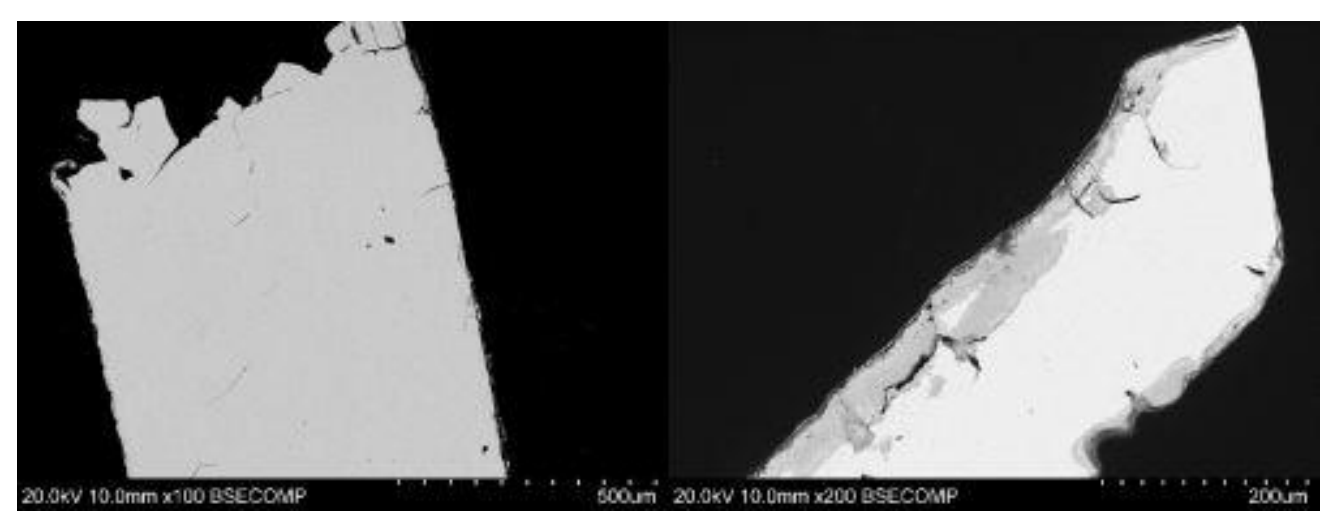

Figure 14: Scanning electron micrographs (SEM) of Mycenaean shaft grave silver: SG520a (left) and SG520b (right)

Similarly, SG865a and SG865b (Figure 15) were taken from rim fragments of a vessel of uncertain shape. The rim had been restored from two fragments (Davis 1977, 168-69, no. 54, figs 134-35 - described in Davis' text as a 'silvered bronze vessel' and as a 'silverplated inlaid bronze'). SG865a is predominantly sound metal, while SG865b is almost completely corroded. The different compositional and LIA signatures suggest that the samples are not from the same silver source (Table 11 and Table 12). We have also considered these samples separately.

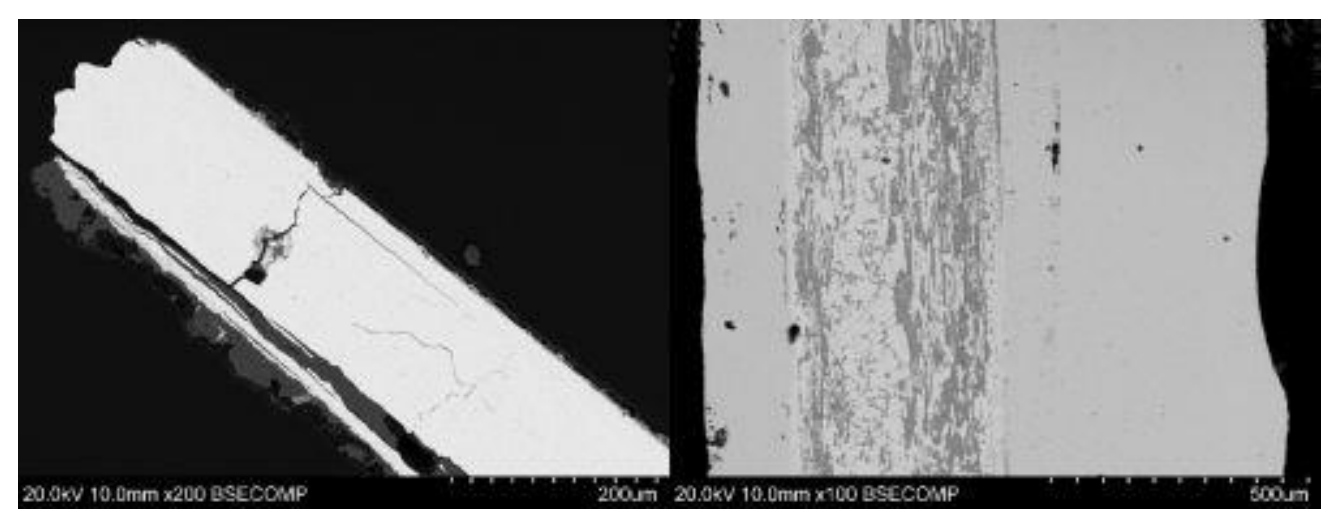

Figure 15: Scanning electron micrographs (SEM) of Mycenaean shaft-grave silver: SG865a (left) and SG865b (right). Note that SG865b is heavily corroded 
We would like to point out that Pernicka et al.'s (1983) LIA and NAA compositional values show some differences from the data presented and measured here. Such differences have been observed previously. For example, three of the 17 vessels measured by the Oxford group were also analysed by the Mainz group (Pernicka et al. 1983) (SG479, SG869, SG876), producing LIA results that were quantitatively different but resulted in similar overall conclusions regarding provenance. Differences were attributed to fragments of different vessels being analysed but with the same National Museum accession number (Stos-Gale and Macdonald 1991). This had been alluded to previously by Davis for SG479 (Davis 1977, 196-98, nos 72-73, fig. 161 - note that this figure shows no. 73 only), who recognised that two different vessels were represented by the single Athens NM479 inventory number. Other issues regarding LIA measurements may stem from the fact that Pernicka et al. $(\underline{1983})$ did not measure the ${ }^{204} \mathrm{~Pb}$ isotope, which is also needed in order to calculate the $\mathrm{Pb}$ crustal age (see below). Furthermore, regarding the compositional data, although Pernicka et al.'s NAA measurements have better detection limits than XRF or EPMA, measurements of elements such as lead and bismuth can be problematic with the NAA technique (Scott 2010, 27). This may explain some differences in the compositional data as Pernicka et al. (1983) did not publish their compositional totals.

Some of the samples are heavily corroded. For example, the sample codes from the LIA appear to refer to repeat analyses: SG479-1, SG479-2 (Stos-Gale 2014) and SG479 (Stos-Gale and MacDonald 1991) have very similar LIA values but the appearance and composition of SG479-1 and SG479-2 are different (Figure 16), which at first suggested that they may have been two different samples. However, even though SG479-1 is more corroded than SG479-2, probably the result of copper corrosion during deposition, the Au/Ag $\times 100$ for these samples are 0.407 (SG479-1) and 0.648 (SG479-2) from our EPMA measurements. These differences potentially reflect inhomogeneity in the samples rather than different samples. Nevertheless, both samples have been treated separately.

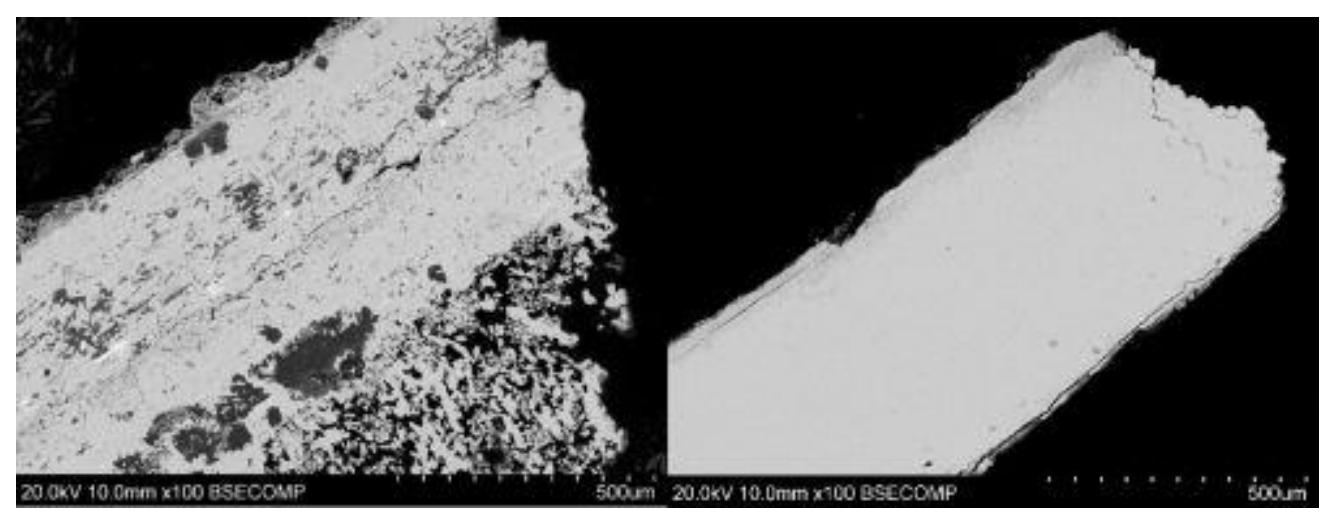

Figure 16: Scanning electron micrographs (SEM) of Mycenaean shaft-grave silver: SG479-1 (left) and SG479-2 (right). Note that SG4791 is heavily corroded 
Sample 3109 is not, in fact, silver but a copper-tin alloy that contains only about $14 w t \%$ of silver. Pernicka et al.'s (1983) analysis of the same sample only showed trace levels of tin, which suggests that we may have examined a completely different sample. Although this sample is included on our plots, we do not believe it to be a representative or reliable piece of Mycenaean shaft-grave silver.

By pointing out these discrepancies, we appear to be questioning the validity of investigating these samples. Nevertheless, although it may not be possible to attribute the provenance of each individual piece securely, the data can still contribute to the overall picture for the silver assemblage of Mycenae in this time period. The analysis that follows takes this zoomed out, whole assemblage, approach.

\subsection{Analysis of silver from Mycenae}

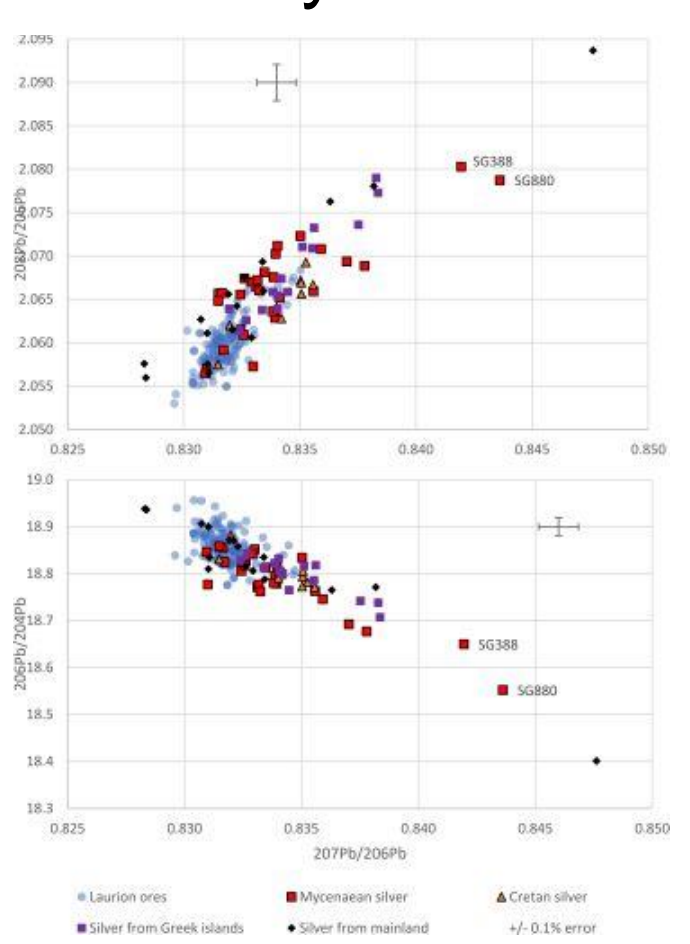

Figure 17: LIA mirror plots of Mycenaean silver objects presented alongside Laurion ores and silver objects plotted in Figure 9 (see $\underline{\text { Table }}$ $\underline{9}$, Table 11 and Table 12; OXALID 2020). At least two of the Mycenaean objects (SG388 and SG880) are clearly not consistent with Laurion. Data from OXALID (2020), Stos-Gale and MacDonald (1991) and Stos-Gale (2014) 
Figure 17 shows LIA mirror plots for the Mycenaean silver, other silver recovered on the mainland and for silver recovered on Crete and other Greek islands shown in Figure 9, alongside the ores from Laurion (see $\underline{\text { Table 9 }}$, Table 11 and Table 12).

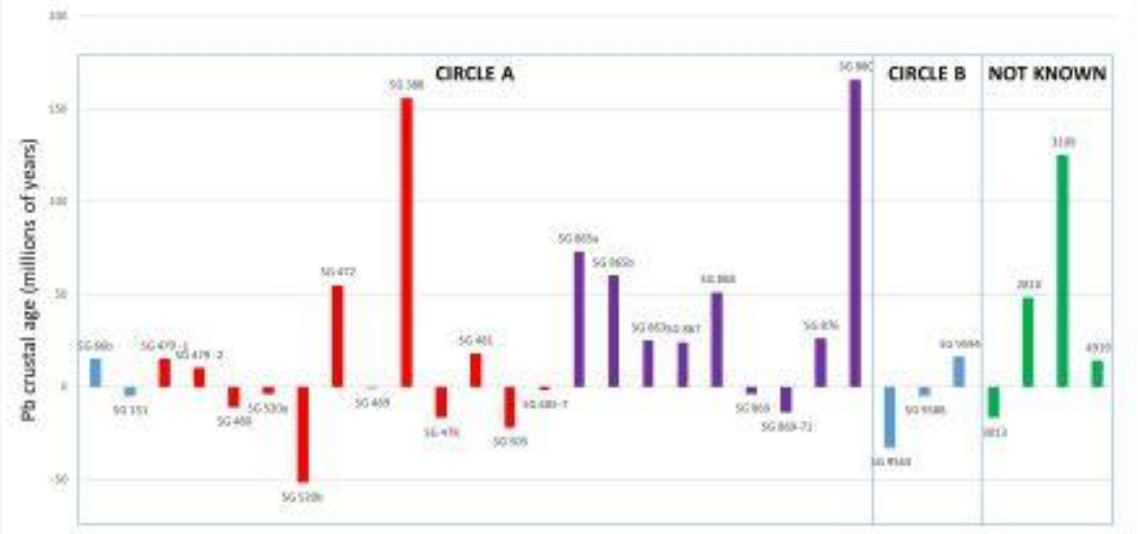

Figure 18: Pb crustal ages (Ma) determined from the two-stage evolution model for the 30 Mycenaean shaft-grave silver samples, using LIA values from Stos-Gale and MacDonald (1991) and Stos-Gale (2014), and parameters from Desaulty et al. (2011). The samples are delineated by find location (i.e. Grave Circles A and B, and unknown). Different colours denote the individual shaft graves (see Tables 11 and 12). There is no obvious pattern between the crustal ages and the find locations. As expected from the LIA plots in Figure 17, two samples (SG388 and SG880) have much higher crustal ages than the majority of the Mycenaean silver

Considering all the samples as a group, the variation in the isotopic signatures is high, reflecting the disparate nature of the dataset (Figure 17). It is immediately apparent that although most of the Mycenaean silver appears to lie within the Laurion LIA field, especially when error bars are considered, at least two pieces fall outside. These two pieces are easily identified (Figure 18) when the LIA values are converted into a $\mathrm{Pb}$ crustal age value (which is also known as the model age, and reflects the geological age of the ore from which the lead in the sample derived) measured in millions of years (Ma) (see data section). Both SG388 and SG880 are associated with ore bodies that are geologically much older than Laurion and Athenian coins (Figure 19). An Anatolian origin has been proposed based primarily on typological parallels (see Figure 20) for these artefacts. 


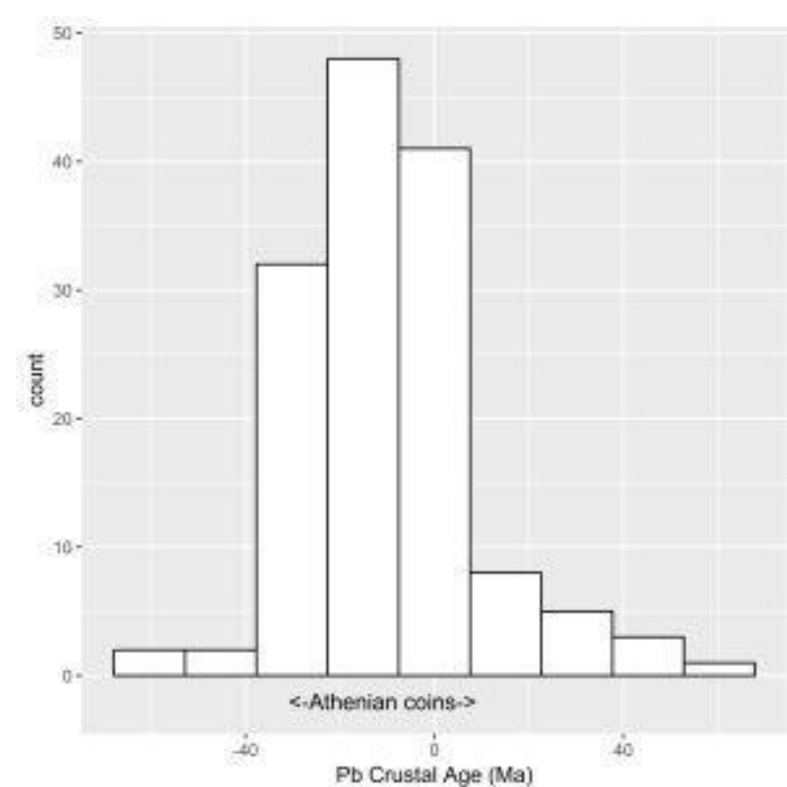

Figure 19: Frequency histogram of the $\mathrm{Pb}$ crustal age (Ma) for ores from Laurion, as calculated from the lead isotopes from the Greek ores database (OXALID 2020) using the two-stage evolution model with parameters from Desaulty et al. (2011). The range of calculated $\mathrm{Pb}$ crustal ages for Athenian coins from the Asyut hoard (Gale et al. 1980) is also presented and shows that these coins are commensurate with silver mined from Laurion 


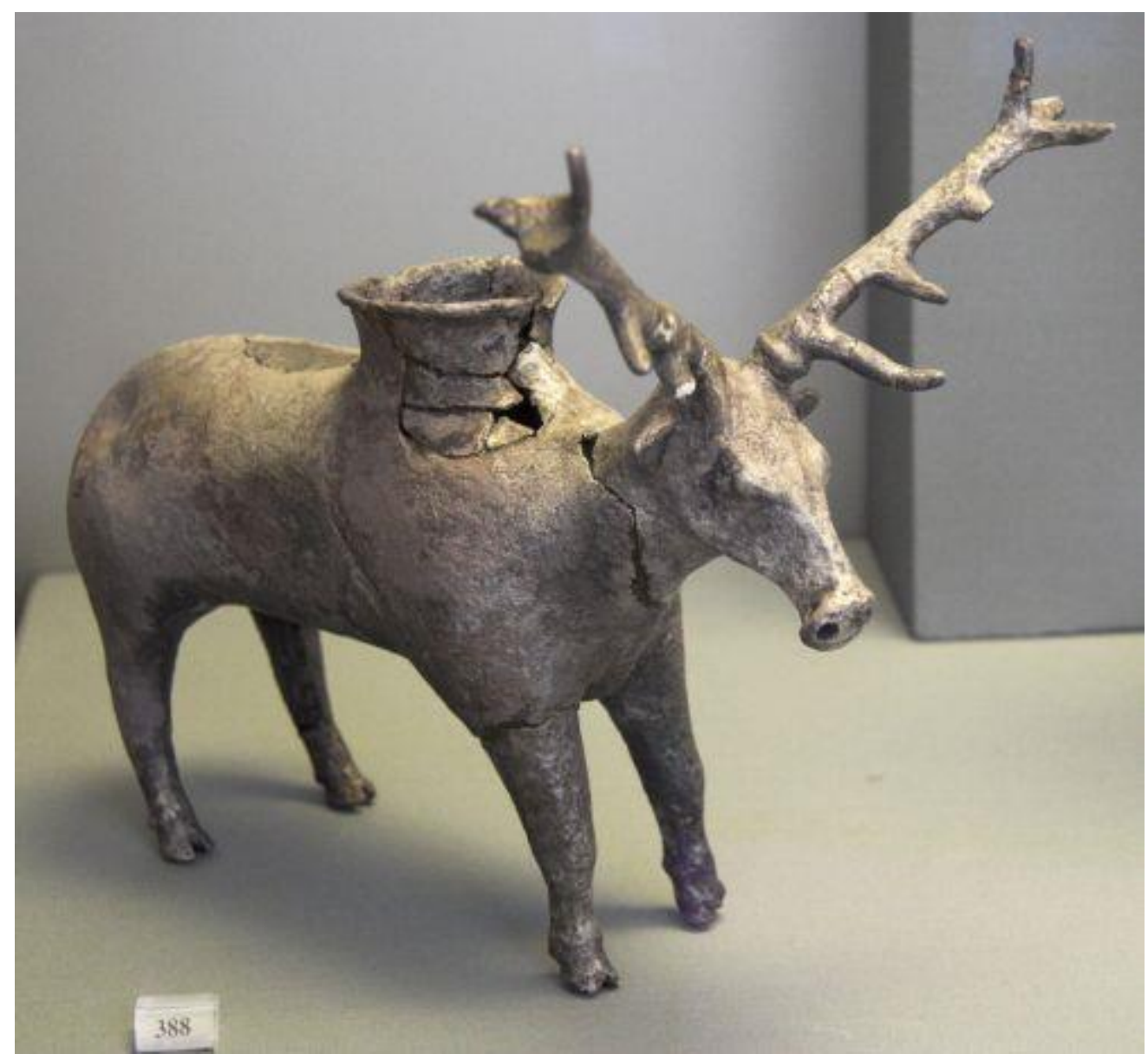

Figure 20: Stag Rhyton (SG388) in the National Museum of Athens (NMA388). Potentially of Anatolian origin as it has no Aegean parallels, with possible comparisons from third millennium contexts, mainly in Anatolia, e.g. Kultepe rhyta (Özgüç and Özgüç 1953); Alaca Höyük bronze and silver stags (Arik 1937). For this reason, its presence at Mycenae has often been interpreted as an heirloom (Davis 1977). Photo Zde (CC-BY-SA-3.0) 
Figure 21 is a plot of $\mathrm{Au} / \mathrm{Ag} \times 100$ against $\mathrm{Pb}$ crustal age $(\mathrm{Ma})$ for the Mycenaean shaft-grave silver. The ranges of Laurion ores and Athenian coins are also plotted and 24 of the 30 samples fall within the range of crustal ages for Laurion ores, with 12 samples falling within the range of Athenian coins. The conservative range from the Athenian silver coins would suggest that 40 per cent of samples may have come into contact with Laurion lead. The full range of Laurion ores could suggest over 80 per cent.

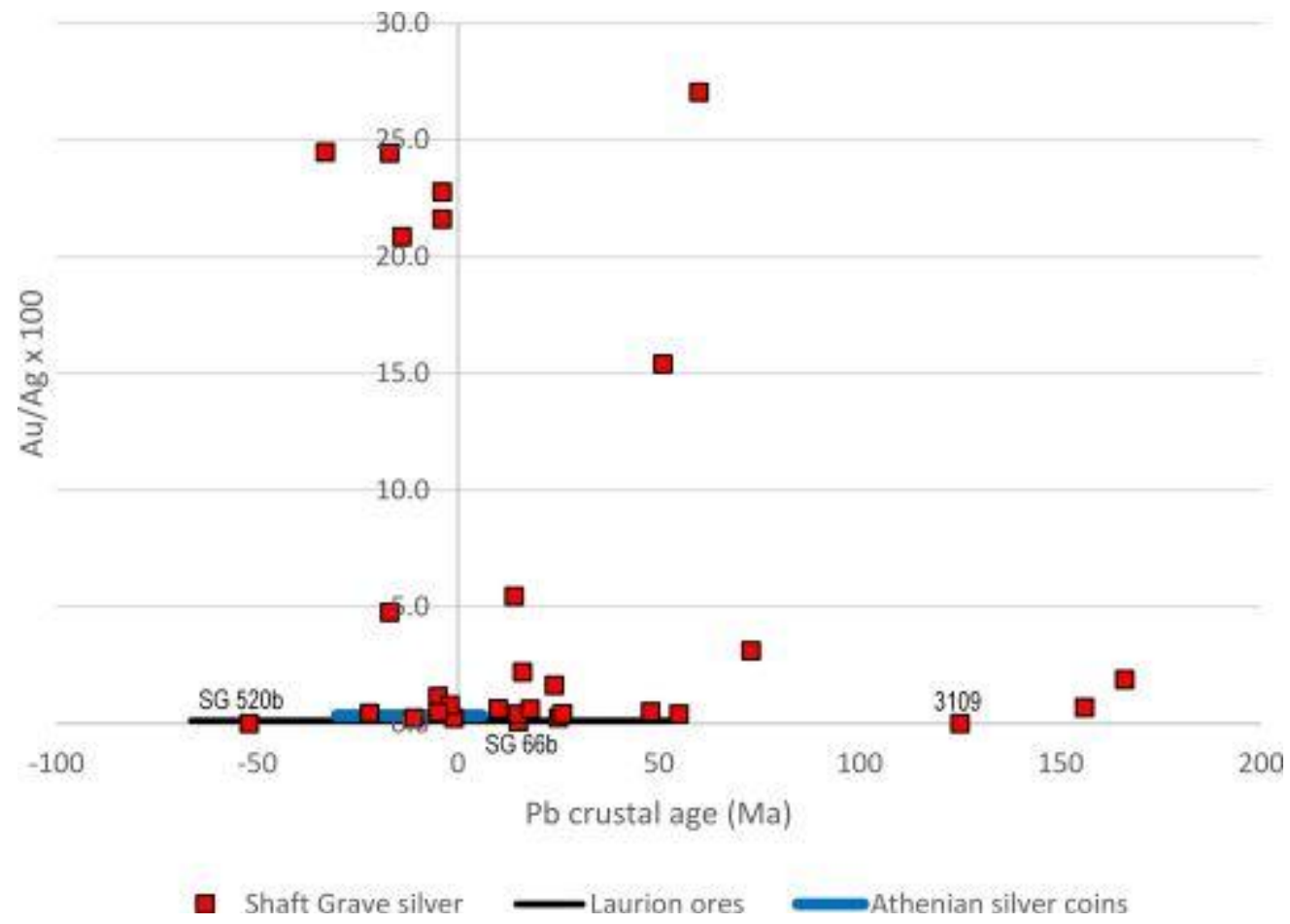

Figure 21: Plot of $\mathrm{Au} / \mathrm{Ag} \times 100$ against $\mathrm{Pb}$ crustal age $(\mathrm{Ma})$ for Mycenaean silver. The ranges of crustal age and their maximum $\mathrm{Au} / \mathrm{Ag}$ $\times 100$ levels are plotted for Laurion ores $(\mathrm{Au} / \mathrm{Ag} \times 100=0.1286)$ and for Athenian coins $(\mathrm{Au} / \mathrm{Ag} \times 100=0.3438)$. The three labelled samples (SG66b, SG520b and 3109) are the only pieces with $\mathrm{Au} / \mathrm{Ag} \times 100$ levels below 0.1

An interesting observation from Figure 21 is that apart from three samples (SG66b, SG520b and 3109) all have Au/Ag $\times 100$ levels in excess of 0.1 . This indicates strongly that, with the exception of these three silver objects, which we are unable to rule out using gold data alone, the remainder are unlikely to have derived from argentiferous galena ores. (Note: 3109 is not silver but a copper-tin alloy that 
contains only about $14 \mathrm{wt} \% \mathrm{Ag}$ ). Although higher gold levels could have resulted from recycling (where gilding or a gold handle was not removed before the silver was placed in the melting pot) or from deliberate mixing to alter the colour of the metal (although generally a level of $20 \%$, or even $30 \%$, gold would not alter the colour of a silver alloy), in our view, the gold level in the majority of samples is more likely to be geological (i.e. silver ores with either low or high levels of gold) as there are no obvious mixing lines. In fact, the presence of appreciable levels of gold and bismuth (which is also present in the majority of silver pieces - Table 11) supports the premise that

oxidised zones were exploited at Laurion (in preference to the sulphidic galena deposits) as these have been shown to have ore shoots exceptionally rich in gold and bismuth (Voudouris and Economou-Eliopoulos 2003; Voudouris 2005, 1089-92; Voudouris et al. 2008). In fact, as alluded to earlier, the presence of gold flecks may have drawn prospectors toward a particular ore (see Bell and Wood in press; Wood 2019), further supporting the argument against argentiferous galena being the source of the Mycenaean shaft-grave silver.

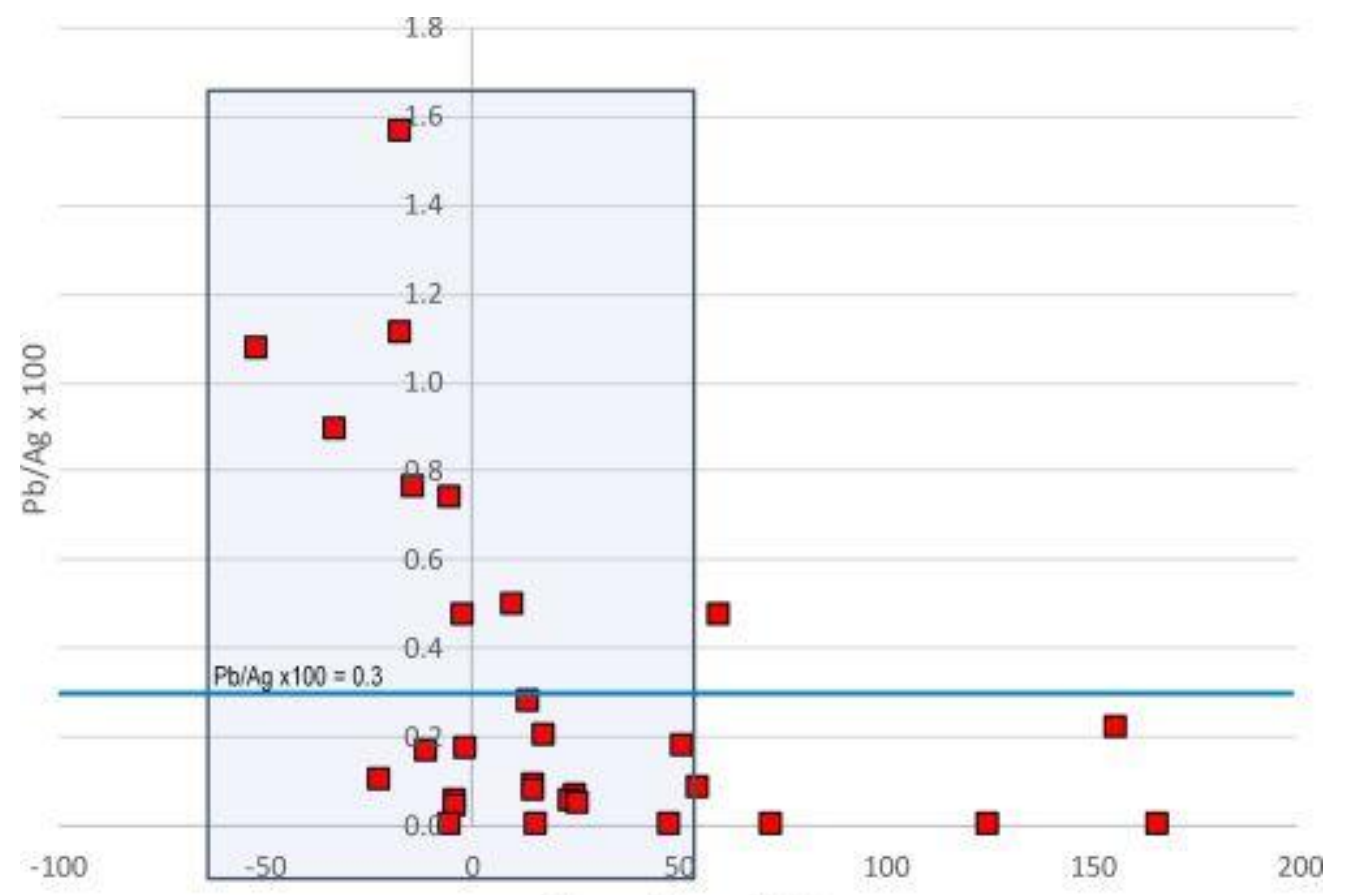

$\mathrm{Pb}$ crustal age $(\mathrm{Ma})$

Figure 22: Plot of $\mathrm{Pb} / \mathrm{Ag} \times 100$ against $\mathrm{Pb}$ crustal age (Ma) for Mycenaean silver (Tables 11 and 12). Most samples fall within the crustal ages of Laurion ores (shaded box), which would suggest that Laurion lead was used to extract silver. There are possibly two groups (higher and lower levels of lead in these samples - see Figure 23). The lower lead levels $(\mathrm{Pb} / \mathrm{Ag} \times 100<0.3)$ could suggest that they had 
not been cupellated, i.e. silver for these objects came from large silver minerals such as large crystals. These samples also have lower levels of bismuth. The crustal ages of these low-lead samples would also suggest they were from Laurion and older sources

Figure 22 shows a plot of the lead content in the silver vs $\mathrm{Pb}$ crustal age (Ma). As mentioned above, silver extracted by cupellation should contain residual lead (see Section 3.3). There are potentially two groups in Figure 22 (samples below and above Pb/Ag $\times 100 \approx$ 0.3 ) which may reflect the two processing methods: silver deriving from large minerals that did not require cupellation, and silver minerals dispersed in rocky matrices that needed to be concentrated using exogenous lead prior to cupellation. This is illustrated in Figure 23, which shows that 21 samples (shaded) appear to form part of a distribution at lower levels of lead $(\mathrm{Pb} / \mathrm{Ag} \times 100<0.3)$ in the silver. These samples could suggest the natural geological distribution of lead in silver minerals at Laurion and around the Aegean (i.e. Iarge silver minerals that could be smelted to recover silver under a cover of charcoal). Conversely, the samples with higher levels of lead (Pb/Ag $\times 100>0.3$ ) do not exhibit an obvious distribution, suggesting that the natural geological signature was eradicated by the process of adding exogenous lead during the cupellation process. This threshold is clearly higher than the minimum level $(\mathrm{Pb} / \mathrm{Ag} \times 100=0.05)$ proposed by Craddock $(\underline{1995}, 213 ; \underline{2014})$ to be an indicator of cupellation, which, to reiterate, was potentially proposed because it was assumed that most early silver had derived from argentiferous lead ores and had been cupellated.

The crustal ages of the ores (Figure 22) would suggest that the silver objects with $\mathrm{Pb} / \mathrm{Ag} \times 100<0.3$ could be made from silver that had been smelted without adding lead and were available at several geological locations - some potentially at Laurion and others from much older ore sources. 


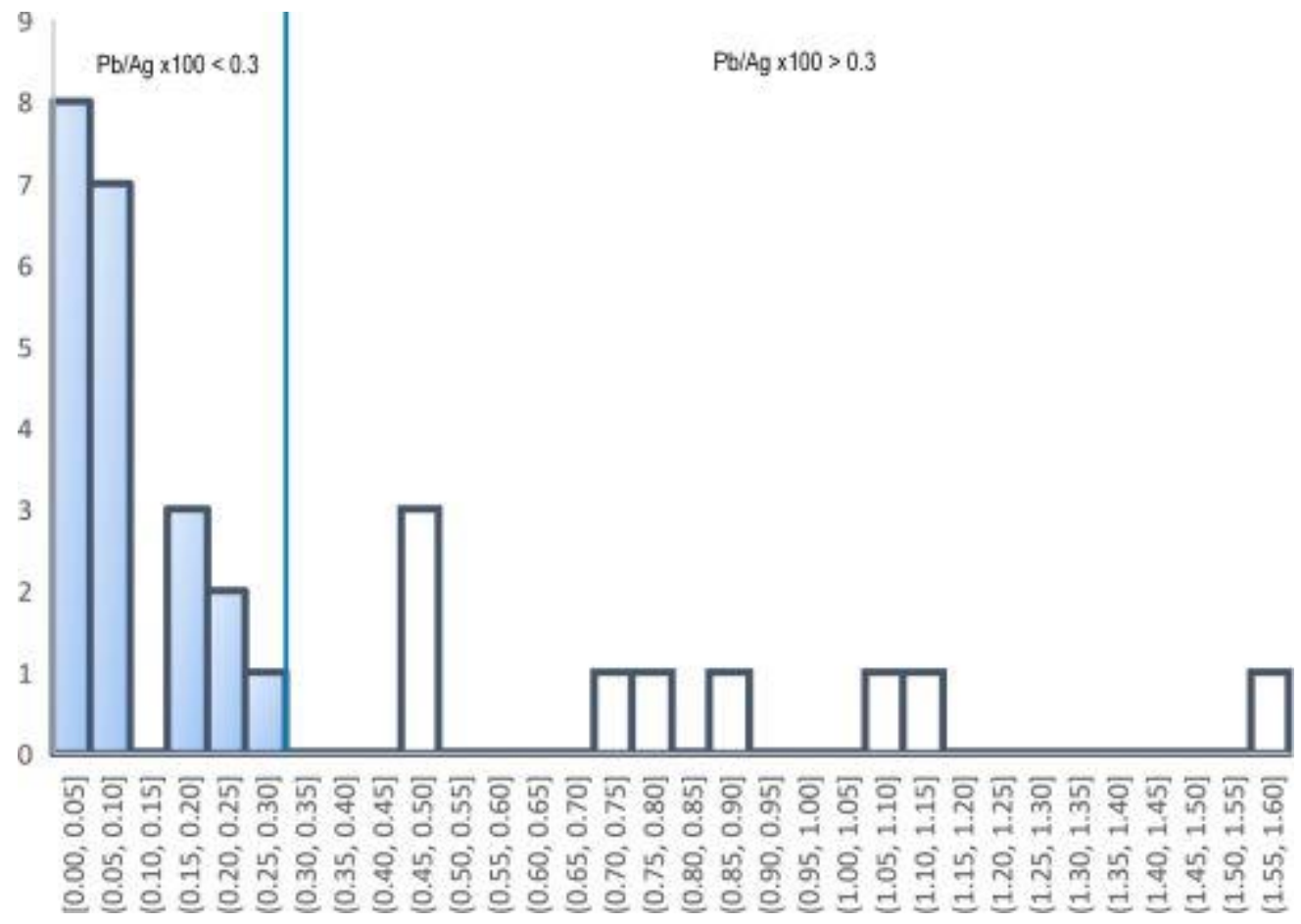

Figure 23: Histogram of the $\mathrm{Pb} / \mathrm{Ag} \times 100$ in the Mycenaean silver measured in this study by EPMA (Table 11). The shaded areas highlight a possible distribution at low levels of lead, which might reflect the natural distribution of lead found in large silver minerals at Laurion and around the Aegean. Higher lead levels were potentially cupellated with exogenous lead, thereby obliterating the signature associated with this distribution

As discussed, silver considered to have been produced by cupellation is generally assumed to have been extracted from argentiferous lead ores. In fact, Pernicka et al. (1983) state explicitly that the Aegean Bronze Age objects they investigated (Figure 13) were cupellated with lead. In our view, cupellation is not in dispute, since in some cases they record significant levels of lead $(\mathrm{Pb} \%$ : $\mathrm{mean}=0.48 ; \mathrm{s}=$ 0.47 ; median $=0.29$; range: bdl-1.4; $\mathrm{n}=12$ ) (see Table 11). However, they also conclude, incorrectly in our view, that the silver must have derived from argentiferous lead ores, and not native silver or cerargyrite, because of the absence of arsenic, tin and antimony. We take issue with this deduction as arsenic, tin and antimony would be absent in cupelled silver: arsenic is volatile and would be vaporised during cupellation (see Wood and Hsu 2019) while both tin and antimony would be enriched in the litharge (Gale et al. $\underline{1980})$. 
In consequence, although the crustal ages of the majority of samples with higher levels of lead $(\mathrm{Pb} / \mathrm{Ag} \times 100>0.3)$ in Figure 22 would support a Laurion origin, the Au/Ag levels indicate that only one of these samples could have been made from the argentiferous galena at Laurion (i.e. SG520b at a crustal age of $-52 \mathrm{Ma}$ has $\mathrm{Au} / \mathrm{Ag} \times 100<0.1$ ). It is therefore more probable that the nine Mycenaean silver pieces with higher lead levels $(\mathrm{Pb} / \mathrm{Ag} \times 100>0.3)$ were extracted from ores using lead from Laurion (with one perhaps from a slightly older ore source at $60 \mathrm{Ma}$ - see Figure 22) to dissolve silver disseminated as inclusions in rock before cupellation, while the silver pieces with $\mathrm{Pb} / \mathrm{Ag} \times 100<0.3$ derived from large silver minerals that did not require the addition of lead at any stage during the extraction process.

This scenario is further supported when bismuth concentrations are considered: the nine samples above the threshold (i.e. $\mathrm{Pb} / \mathrm{Ag} \times 100$ $>0.3$ ) in Figure 23 have bismuth concentrations that are higher (Bi\%: mean $=0.589 ; \mathrm{s}=0.571 ;$ median $=0.493 ; \mathrm{n}=9 ;$ range: bdl-1.731) than those below this threshold (Bi\%: mean $=0.158 ; \mathrm{s}=0.162$; median $=0.062 ; \mathrm{n}=20$; range: bdl-0.497) (note that these normalised bismuth concentrations do not include the predominantly copper-tin sample 3109). These differences would lend support to the view that exogenous lead, which is often associated with bismuth particularly at Laurion (Voudouris 2005), was added to silver ores that had lower lead and bismuth concentrations, resulting in higher concentrations of residual lead and bismuth in the silver used to make objects.

Another piece of evidence supporting the notion that the silver found in Mycenae was produced using two different methods is that silver objects with levels of lead below the empirical threshold (i.e. $\mathrm{Pb} / \mathrm{Ag} \times 100<0.3$ ) are generally less corroded than those with lead concentrations greater than this. Of the 20 silver samples below the empirical threshold (i.e. excluding the copper-tin sample 3109 ), 13 can be classified as sound silver metal, as evidenced by the EPMA compositional totals (Table 11). Of the nine samples above the threshold, seven were corroded. Although an object's burial time and the average temperature, moisture content, $\mathrm{pH}$ and chemical composition of the burial environment affect levels of corrosion, this could indicate that silver objects that derive from dispersed silver minerals embedded in host rock (which require concentration with lead before cupellation), corrode more readily than those made of silver derived from the direct smelting of large silver minerals. Since higher levels of lead can precipitate out of solution causing embrittlement, thereby making the silver more susceptible to corrosion (Wanhill 2003), it is feasible that ancient silver objects produced from large silver minerals that did not require the addition of lead are better able to survive the ravages of deposition, irrespective of the time period from which they hail.

In effect, it may be that the paucity of silver in post-shaft grave contexts at Mycenae, and throughout the Aegean in the Iron Age, can be explained by the increasing rarity of dry silver ores and by the method utilised to extract dispersed silver from these ores, which resulted in objects that corroded before they could enter the archaeological record.

In summary, the analyses on the Mycenaean silver suggest the following: 
i. Silver from large minerals from a number of locations (e.g. dry silver ores such as cerargyrite) was extracted by smelting, probably just under a cover of charcoal.

This is supported by the silver samples with gold levels in excess of argentiferous galena $(\mathrm{Au} / \mathrm{Ag} \times 100>0.1)$, with low levels of lead $(\mathrm{Pb} / \mathrm{Ag} \times 100<0.3)$ and low levels of bismuth that exhibit a wide range of crustal ages.

ii. Silver minerals were found disseminated in host rocks and Laurion lead was used to extract them.

This is supported by the silver samples that have crustal ages consistent with Laurion and have higher levels of lead $(\mathrm{Pb} / \mathrm{Ag} \times 100$ $>0.3$ ) and higher levels of bismuth. Since the LIA signature of the silver source would be affected by the addition of Laurion lead, the silver may have derived from Laurion and/or elsewhere, as evidenced by silver with higher crustal ages in Figure $\underline{21}$ and Figure 22 as well as litharge and silver with LIA signatures consistent with Laurion which have been found on Kea, Crete and other islands.

\section{Discussion}

The main conclusion of this article is that the earlier hypothesis, which claimed that Laurion was not exploited for silver until the mid-first millennium BCE, is largely correct. In effect, we believe the evidence does not support the proposition that argentiferous lead ores, such as the galena deposits at Laurion, were exploited for silver in the Bronze Age. In fact, we suggest that any correlation between lead and silver metallurgy in the archaeological record has been misattributed to the geological association between lead and silver in argentiferous lead ores.

Although the presence of litharge suggests the cupellation of argentiferous lead to produce silver, we have presented evidence that this does not necessarily mean that the lead and silver must have derived from the same source. We propose that silver minerals dispersed in dry silver ores were exploited at Laurion and elsewhere in the Bronze Age. Once native silver and large silver minerals became increasingly difficult to find, it was necessary to extract silver and silver minerals from ores that were more challenging (as the silver/silver minerals were dispersed in rocky matrices). Since lead can extract silver from crushed dry silver ores and subsequently release silver in the cupellation process, a correlation between silver and lead metallurgy would be expected without necessarily requiring that both metals were sourced from the same mineral.

We believe that numbers of silver artefacts in the archaeological record can be explained as follows:

i. Silver was first exploited from native silver and large silver minerals. As this type of mineral resource became exhausted, the amount of silver produced and the number of objects deposited in the archaeological record decreased, as shown in Gale's 
analysis (Gale $\underline{1980}, 161-96)$ of Branigan's (1974, 155-205) and Buchholz's (1972, 21-36; Buchholz and Karageorghis $\underline{1973})$ investigations of silver objects between the EBA and MBA (Table 1).

ii. The technology of using exogenous lead to extract silver dispersed in ores (i.e. where it was difficult to extract the silver by separating silver from gangue by mechanical means) could have resulted in increased access to silver metal and an increased number of objects produced and deposited in the archaeological record. This increase is perhaps manifested in the relative wealth of the Mycenaean shaft-grave silver at the MBA-LBA transition, as about a third of the objects we measured appear to have had lead added. This coincides with Renfrew's characterisation of a resurgence in metallurgical activity in the LBA (Renfrew 1967, 120) and an associated increase in the number of silver objects.

iii. As these dispersed silver ores, in turn, started to run out, the amount of silver produced would have, again, decreased. This is evidenced by the low number of silver objects in the post-shaft grave contexts at Mycenae and the few silver objects found in the Early Iron Age Aegean (Dickinson 2006, 119-20). Furthermore, it is possible that the method to extract silver from dry silver ores dispersed in host rock resulted in silver with a greater propensity to corrode during deposition.

Eventually it became necessary to find new sources of silver that could be exploited using the same technology. The widespread destruction of sites around the Eastern Mediterranean around 1200 BCE was particularly hard felt in Greece and the Greek islands with the collapse of the palaces, and potentially released not only merchants but also skilled craftsmen (Zaccagnini 1983) to conduct exchange on their own terms using skills and knowledge, learnt in the Bronze Age, to source key commodities through long distance trade.

Nowhere was this truer than in Phoenicia, which had not suffered destruction at the end of the LBA and was as rich in maritime enterprise as it was poor in indigenous resources, particularly metals (Bell 2016). When Phoenician ventures started to access lberian silver in the early first millennium BCE, they eschewed galena ores in south-east lberia and concentrated their efforts on argentiferous jarosite minerals in the south-west, beyond the Straits of Gibraltar (Wood et al. 2019; Wood and Montero-Ruiz 2019; Wood et al. 2020). More fundamentally than this, they may have transferred the necessary extractive technology to lberia that they had observed, or possibly developed in collaboration with local miners and metallurgists, on Cyprus in the earliest Iron Age (Wood et al. 2020; Bell and Wood in press). This application of technology may, therefore, have been one of the key drivers that influenced silver trade routes in the Iron Age: jarosite ores on Cyprus and in Iberia were exploited using, potentially, a similar technology to that used to exploit silver in northern Syria and Anatolia, on the island of Siphnos, and at Laurion and around the Aegean during the Bronze Age - namely, adding lead to argentiferous lead-poor ores to produce argentiferous lead followed by cupellation. Moreover, this technology appears to have been adapted later by the Lydians at Sardis in the 7th century BCE (Craddock 2000, 200-11; Wood et al. 2017a), not to extract silver from ores, but to recover silver from the parting vessels used to purify gold from silver, and by Mediterranean silversmiths to refine leadsilver ingots (Wood and Montero-Ruiz 2019). In summary, adding lead to silver minerals to produce argentiferous lead, and the subsequent cupellation of this lead for silver was not new technology but its application, particularly to jarosites in Iberia, was to open up a new period of relative abundance of silver from one end of the Mediterranean to the other. 
The compositional data from the shaft-grave silver at Mycenae and silver and lead objects recovered around and beyond the Aegean appear to provide support to the hypothesis that lead was used in the Bronze Age solely for making lead objects and for extracting silver from silver minerals disseminated in ores. Almost all silver objects investigated here appear to have higher Au/Ag levels than found in argentiferous galena, and many seem not to have undergone cupellation (as evidenced by their relatively low concentrations of lead and bismuth). If so, it seems likely that local silver minerals were exploited in the Aegean and it was the lead required for their extraction that travelled. It is also highly likely that prospectors carried with them lead from one location to extract silver dispersed in silver minerals at another, and that much of this lead came from Laurion. The predominance of Laurion isotopic signatures in Aegean silver (e.g. Mycenae, other mainland sites, Crete and other Greek islands) is potentially, therefore, due to Laurion lead. For example, in the EBA, it is likely that lead from Siphnos was used to extract silver from the ores found on Siphnos until these local lead sources began to run out (i.e.

potentially in the MBA). At this point, Laurion lead became the more viable silver collector. Silver produced at Thorikos in the LBA probably derived from silver minerals near the Laurion lead mines and was extracted with lead from Laurion. Similarly, Crete, Kea and Dhaskalio have litharge that is consistent with Laurion lead, and Crete has silver that is consistent with Laurion lead being used to extract silver from silver ores on Crete.

We consider that lead, from Laurion and other available locations, was a utilitarian material during the Bronze Age to make objects and to extract silver from visible silver inclusions in dry silver ores. We do not believe that lead ores were used as a source of silver in their own right until the mid-first millennium BCE (and according to field surveys and Meyers' model, until the 7th century CE in Iran and Anatolia perhaps following a tradition dating back to the processes used at Habuba Kabira and Fatmali-Kalecik in the late fourth millennium BCE). Essentially, Laurion was not only a source of lead that could be used to make objects and to collect silver but also, inadvertently, exported its lead isotope signature to the silver and metallurgical debris recovered further afield, thanks to ancient silver ore prospectors. In effect, although lead was available at Laurion, silver was potentially available at a number of locations around the Bronze Age Aegean and beyond. If it is considered that centralised control over Laurion would have only become necessary when the full potential of its silver-bearing lead ores was discovered, the dearth of archaeological evidence suggesting any centralised authority at Laurion would support the notion that this region was considered principally as a source of lead until the Archaic/Classical period.

\section{Concluding Remarks}

We have attempted to corroborate our conclusions from several angles, but it is perhaps the levels of silver in argentiferous lead ores that present the most convincing case against their exploitation until the middle of the first millennium BCE. Silver concentrations are so low as to be invisible to the naked eye and enormous quantities of lead ore would need to be smelted to produce a single silver object. Such a scenario is not supported by the archaeological record of the Bronze Age Aegean or further afield, particularly as only low amounts of lead-smelting slag have been found in association with litharge in ancient metallurgical contexts. Moreover, it is difficult to 
envisage the trade and transportation of large amounts of lead (or lead ores) from Laurion via the Western string of Aegean islands to be later cupellated and refined, in order to explain the absence of slag on Greek islands where litharge has been recovered. In fact, the Laurion signature for the Bronze Age litharge found on Crete, Kea and other islands in the Aegean is more convincingly explained by Laurion lead being used to collect silver from local silver-bearing ores (until even these ores were exhausted) rather than argentiferous lead and/or lead ores from Laurion being transported to these locations in order for local ancient metallurgists to extract their trace levels of silver. Furthermore, it is also very difficult to reconcile the almost normally distributed concentrations of silver found in Bronze Age lead objects with the practice of selecting deposits of galena (or lead from test smelts) for subsequent silver or lead processing.

How argentiferous lead ores were eventually recognised as being a potential source of silver is difficult to say. The chronology of lead that has not been de-silvered reaches to Archaic times. Moreover, the fact that early Attic coins do not have LIA signatures associated with Laurion and higher Au/Ag ratios than later 'Athenian owls' (Kraay 1976, 56-60; Gale et al. 1980) could imply that argentiferous lead ores, with their invisible concentrations of silver, were only exploited for silver once assaying became precise and accurate. In other words, at some point (probably when control over silver purity became integral for coinage as a store of value) perhaps someone noticed that the amount of silver recovered during cupellation was slightly greater than the amount of silver being assayed, and deduced that this extra silver must have been derived from the lead source introduced in the cupellation process.

Nonetheless, it is likely that the exploitation of argentiferous lead deposits for silver not only required that lead ores were recognised as a silver source, but also a large workforce (most probably in the form of slaves or enforced labourers) to scale the operation to make it worthwhile.

Without question, the silver output of Laurion made it the most important mining district of ancient Greece during the 5th and 4th centuries BCE. The resolve (and labour) the Greeks applied to extracting vast amounts of silver from these lead ores produced a source of wealth that contributed to the power of Athens and Classical Greece (Ardaillon 1897; Healy 1978, 133; Conophagos 1980;

Domergue 2008, 45) and backed it with bullion. However, before the exploitation of argentiferous lead ores for silver began in the middle of the first millennium BCE at Laurion, the technology of adding lead to lead-poor silver-bearing ores (described by Pliny in the 1st century CE and Agricola and Erker in the 16th century CE), probably originated in Anatolia in the late fourth millennium BCE. It was then developed in Siphnos in the third millennium BCE, advanced at Laurion itself and around the Aegean to access ores with visible but dispersed silver in the mid-second millennium BCE, practised in Cyprus at the transition of the Bronze and Iron Ages, adapted by Lydians at Sardis in the 7th century BCE to recover silver from gold-parting vessels and applied by Mediterranean silversmiths to refine lead-silver ingots. It also appears that this technology was successfully implemented to acquire silver for artefacts found in the shaft graves at Mycenae and later to extract massive quantities of silver from the lead-poor jarosite ores in south-west lberia successively by Phoenicians, Carthaginians and Romans throughout the first millennium BCE. 


\section{Acknowledgements}

The authors would like to thank the LAHP/AHRC for funding the work of Jonathan Wood and the Cambridge Commonwealth, European and International Trust and Ministry of Education, Taiwan, for funding the work of Yi-Ting Hsu. We would also like to extend our sincere thanks to Dr Zofia Stos-Gale for providing us with silver from the Mycenaean shaft graves which stimulated this investigation, as well as for the remarkable OXALID database (Oxford Archaeological Lead Isotope Database), and for the insightful comments from Professors Jeremy Rutter, Thilo Rehren, John Bennet and Dr Peter Liddel, which helped develop our article.

Data ${ }_{\text {https:/intarch.ac.ukjiounalissues6/9/datantm! }}$ 


\section{Bibliography}

Albarède, F., Desaulty, A.-M. and Blichert-Toft, J. 2012 'A geological perspective on the use of Pb isotopes in archaeometry', Archaeometry 54, 853-67. https://doi.org/10.1111/j.1475-4754.2011.00653.x

Anguilano, L., Rehren, T., Muller, W. and Rothenberg, B. 2009 'Roman jarosite exploitation at Rio Tinto (Spain)' in A. Giumlia-Mair and A. Hauptmann (eds) Archaeometry in Europe I/ 2007, Milano: Associazione Italiana di Metallurgia. 21-29.

Ardaillon, E. 1897 Les Mines du Laurion dans l'antiquité, Charleston: Nabu Pres.

Arik, R.O. 1937 Les Fouilles d'Alaca Höyük: Entreprises par la société d'histoire turque. Rapport preliminaire sur les travaux en 1935, Ankara: Publications de la Société Turque, Series V , no.1.

Aulsebrook, S. 2018 'Chicken or egg? Rethinking the relationship between the silver and tinned ceramic vessel assemblages', Annual of the British School at Athens 113, 75-118. https://doi.org/10.1017/S0068245417000120

Bartelheim, M., Contreras Cortes, F., Moreno Onorato, A., Murillo-Barroso, M. and Pernicka, E. 2012 'The silver production of the South Iberian El Agar culture; a first look at production and distribution', Trabajos de Prehistoria 69, 293-

309. https://doi.org/10.3989/tp.2012.12093

Bastin, E.S. 1922 'Primary native silver ores near Wickenburg, Arizona, and their bearing on the genesis of the silver ores of Cobalt, Ontario', US Geological Survey Bulletin 735, 131-55. https://doi.org/10.3133/b735E

Bell, C. 2016 'Phoenician trade: the first 300 years' in J.C. Moreno Garcia (ed) Dynamics of Production in the Ancient Near East 1300 500 BC, Oxford: Oxbow Books. 91-105.

Bell, C. and Wood, J.R. in press 'Reflections on the westward expansion of the Phoenicians in the Early Iron Age: the search for silver and technology transfer' in M. Kõiv, R. Kletter, U. Nõmmik, V.Sazonov and I. Volt (eds) Responses to the 12th Century BC Collapse: Recovery and Restructuration in the Early Iron Age Near East and Mediterranean, Melammu Workshop at the University of Tartu (Estonia), 7-9 June 2019, Germany. 
Birch, T., Westner, K.J., Kemmers, F., Klein, S., Höfer, H.E., and Seitz, H.-M. 2020 'Retracing Magna Graecia's silver: coupling lead isotopes with a multi-standard trace element procedure', Archaeometry 62, 81-108. https://doi.org/10.1111/arcm.12499

Branigan, K. 1968 'Silver and lead in prepalatial Crete', American Journal of Archaeology 72, 219-29. https://doi.org/10.2307/503550

Branigan, K. 1974 Aegean Metalwork of the Early and Middle Bronze Age, Oxford: Clarendon Press.

Broodbank, C. 2013 The Making of the Middle Sea: A History of the Mediterranean from the Beginning to the Emergence of the Classical World, London: Thames and Hudson.

Buchholz, H.G. 1972 'Das Blei in der Mykenischen Kultur und inder Bronzezeitlichen Metallurgie Zyperns', Jahrbuch des Deutschen Archäologischen Instituts 87, 1-59.

Buchholz, H.G. and Karageorghis, V. 1973 Prehistoric Greece and Cyprus: An Archaeological Handbook, New York: Phaidon Press.

Butcher, K. and Ponting, M. 2014 The Metallurgy of Roman Silver Coinage: From the reform of Nero to the reform of Trajan, Cambridge: Cambridge University Press. https://doi.org/10.1017/CBO9781139225274

Caskey, M., Mendoni, L., Papastamataki, A. and Beloyannis, N. 1988 'Metals in Keos: a first approach' in P.G. Marinos and G.C. Koukis (eds) The Engineering Geology of Ancient Works, Monuments and Historical Sites: Preservation and Protection, Rotterdam and Brookfield. 1739-45.

Childe V.G. 1936 Man Makes Himself,. London: Watts.

Conophagos, C. 1980 Le Laurium antique et la technique grécque de la production de l'argent, Athens.

Craddock, P.T. 1995 Early Metal Mining and Production, Edinburgh. https://doi.org/10.2355/isijinternational.54.1085

Craddock, P.T. 2000 'Reconstruction of the salt cementation process at the Sardis refinery' in E. Ramage and P.T. Craddock (eds) King Croesus' Gold: Excavations at Sardis and the history of gold refining, London: British Museum Press, 200-11.

Craddock, P.T. 2014 'Production of silver across the ancient world', ISIJ International 54, 1085-92. 
Davis, E.N. 1977 The Vapheio Cups and Aegean Gold and Silver Ware, Oxford: Garland Publishing Inc.

Davis, J.L. and Cherry, J.F. 1990 'Spatial and temporal uniformitarianism in Late Cycladic I: perspectives from Kea and Milos on the prehistory of Akrotiri' in D. Hardy, C.G. Doumas, J.A. Sakellarakis and P.M. Warren (eds) Thera and the Aegean World III, London: The Thera Foundation. 185-200.

Davis, J.L. and Stocker, S.R. 2016 'The Lord of the Gold Rings: the Griffin Warrior of Pylos', Hesperia: The Journal of the American School of Classical Studies at Athens 85(4), 627-55. https://doi.org/10.2972/hesperia.85.4.0627

Davis, J.L. and Stocker, S.R. 2018 'The gold necklace from the grave of the Griffin Warrior at Pylos', Hesperia: The Journal of the American School of Classical Studies at Athens 87(4), 611-32. https://doi.org/10.2972/hesperia.87.4.0611

De Jesus, P.S. 1980 The Development of Prehistoric Mining and Metallurgy in Anatolia, Oxford: BAR International Series 74.

Desaulty, A-M., Telouk, P., Albalat, E. and Albarède, F. 2011 'Isotopic Ag-Cu-Pb record of silver circulation through 16th-18th century Spain', PNAS 108, 9002-7. https://doi.org/10.1073/pnas.1018210108

Dickinson, O. 1977 The Origins of Mycenaean Civilization, Götenberg.

Dickinson, O. 2006 The Aegean from Bronze Age to Iron Age: Continuity and Change Between the Twelfth and Eighth Centuries BC, London: Routledge. https://doi.org/10.4324/9780203968369

Domergue, C. 2008 Les mines antiques: la production des métaux aux époques grecque et romaine, Paris.

Efe, T. and Fidan, E. 2006 'Pre-Middle Bronze Age metal objects from inland Western Anatolia: a typological and chronological evaluation', Anatolia Antiqua XIV, 15-43. https://doi.org/10.3406/anata.2006.1062

Ellis Jones, J. 1982 'The Laurion silver mines: a review of recent researches and results', Greece and Rome 29(2), 169-

83. https://doi.org/10.1017/S0017383500027522

Forbes, R.J. 1950 Metallurgy in Antiquity: A notebook for archaeologists and technologists., Leiden.

Forsyth, P.Y. 1997 Thera in the Bronze Age (American University Studies), New York: Peter Lang. 
Friend, J.N. and Thorneycroft, W.E. 1929 'The silver content of specimens of ancient and medieval lead', Journal of the Institute of Metals XLI, 105-17.

Gale, N.H. 1978 'Lead isotopes and Aegean metallurgy' in C. Doumas (ed) Thera and the Aegean World I, London: Aris and Phillips. 529-45.

Gale, N.H. 1980 'Some aspects of lead and silver mining in the Aegean' in C. Doumas, J.A. Sakellarakis and D.A. Hardy (eds) Thera and the Ancient World II, Volume 2, London: The Thera Foundation. 161-196.

Gale, N.H. and Stos-Gale, Z.A. 1981a 'Cycladic lead and silver metallurgy', Annual of the British School at Athens 76, 169224. https://doi.org/10.1017/S0068245400019523

Gale, N.H. and Stos-Gale, Z.A. 1981b 'Lead and silver in the Ancient Aegean', Scientific American 244, 176-

93. https://doi.org/10.1038/scientificamerican0681-176

Gale, N.H. and Stos-Gale, Z.A. 1981c 'Ancient Egyptian silver', Journal of Egyptian Archaeology 67, 103-

15. https://doi.org/10.2307/3856605

Gale, N.H. and Stos-Gale, Z.A. 1987 'Cross-cultural Minoan networks and development of metallurgy in Bronze Age Crete' in S. La Niece, D. Hook and P. Craddock (eds) Metals and Mines: Studies in Archaeometallurgy, London. 103-11.

Gale, N.H., Gentner, W. and Wagner, G.A. 1980 'Mineralogical and geographical silver sources of archaic Greek coinage' in D.M. Metcalf and W.A. Oddy (eds) Metallurgy in Numismatics I, London: The Royal Numismatics Society. 3-49.

Gale, N.H., Stos-Gale, Z.A. and Davis, J.L. 1984 'The provenance of lead used at Ayria Irini, Keos', Hesperia 53, 389406. https://doi.org/10.2307/148020

Georgakopoulou, M. 2018 'Metal production, working and consumption across the sites at Dhaskalio and Kavos' in C. Renfrew, O. Philaniotou, N. Brodie, G. Gavalas and M.J. Boyd (eds) The Marble Finds from Kavos and the Archaeology of Ritual, Cambridge: McDonald Institute for Archaeological Research, McDonald Institute Monographs. 501-32.

Gitler, H., Ponting, M. and Tal, O. 2008 'Metallurgical analysis of Southern Palestinian coins of the Persian period', INR 3, $13-27$. 
Gitler, H., Ponting, M. and Tal, O. 2009 'Athenian Tetradrachms from Tel Mikhal (Israel): a metallurgical perspective', AJN 21, $29-49$.

Hauptmann, A., Klein, S., Paoletti, P., Zettler, R.L. and Jansen, M. 2018 'Types of gold, types of silver: the composition of precious metal artifacts found in the Royal Tombs of Ur, Mesopotamia', Zeitschrift für Assyriologie 108, 100-31. https://doi.org/10.1515/za-2018-0007

Hauptmann, A., Schmitt-Strecker, S., Begemann, F. and Palmieri, A. 2002 'Chemical composition and lead isotropy of metal objects from the 'Royal' tomb and other related finds at Arslantepe, Eastern Anatolia', Paléorient 28, 43-70. https://doi.org/10.3406/paleo.2002.4745

Healy, J.F. 1978 Mining and Metallurgy in the Greek and Roman World, London: Thames and Hudson.

Healy, J.F. 1999 Pliny the Elder on Science and Technology, Oxford: Oxford University Press.

Hess, K., Hauptmann, A., Wright, H. and Whallon, R. 1998 'Evidence of fourth millennium BC silver production at Fatmali-Kalecik, East Anatolia', Metallurgica Antiqua 8, 57-67.

Hoover, H.C. and Hoover, L.H. 1950 Georgius Agricola: De re metallica, New York.

Hopper, R.J. 1968 'The Laurion mines: a reconsideration', Annual of the British School at Athens 63, 293326. https://doi.org/10.1017/S006824540001443X

Kakavogianni, O., Douni, K. and Nezeri, F. 2008 'Silver metallurgical finds dating from the end of the Final Neolithic Period until the Middle Bronze Age in the Area of Mesogeia' in I. Tzachili (ed) Aegean Metallurgy in the Bronze Age, Proceedings of an International Symposium Held at the University of Crete, Rethymnon, Greece, on November 19-21, 2004, Athens. 45-57.

Karakaya, I. and Thompson, W.T. 1987 'The Ag-Pb (silver-lead) system', Bulletin of Alloy Phase Diagrams 8, 32634. https://doi.org/10.1007/BF02869268

Karo, G. 1930/1933 Die Schachtgräber von Mykenai, Munich.

Kassianidou, V. and Knapp, A.B. 2005 'Archaeometallurgy in the Mediterranean: the social context of mining, technology, and trade' in E. Blake and A.B. Knapp (eds) The Archaeology of Mediterranean Prehistory, New Jersey: Blackwell. 215-

51. https://doi.org/10.1002/9780470773536.ch9 
Kelder, J.M. 2016 'Mycenae, rich in silver' in K. Kleber and R. Pirngruber (eds) Silver, Money and Credit, a Tribute to Robartus J. van der Spek on the Occasion of his 65th Birthday on 18th September 2014, Leiden. 307-17.

Kepper, J. 2004 'A hindered-settling model applied to the flat-washing platforms at Laurium, Greece', Historical Metallurgy 38, 75-83.

Kepper, J. 2005 'Third contact ore mineralogy at Laurium, Greece', Historical Metallurgy 39, 1-11.

Kilias, S.P., Naden, J., Cheliotis, I., Shepherd, T.J., Constandinidou, H., Crossing, J. and Simos, I. 2001 'Epithermal gold mineralisation in the active Aegean volcanic arc: the profit is Ilias deposit, Milos Island, Greece', Miner. Deposita 36, 32-

44. https://doi.org/10.1007/s001260050284

Klein, S. and Hauptmann, A. 2016 'Ur, Mesopotamia: the lead metal from Pit X', Metalla 22(1), 136-40.

Kraay, C. 1976 Archaic and Classical Coins, London: Methuen.

Krysko, W.W. 1988 'Possible composition of early ores at Thorikos' in J. Ellis-Jones (ed) Aspects of Ancient Mining and Metallurgy: Acta of a British School at Athens Centenary Conference at Bangor, 1986, Bangor. 88-92.

Legarra Herrero, B. 2004 'About the distribution of metal objects in Prepalatial Crete', Papers from the Institute of Archaeology 15, 2951. https://doi.org/10.5334/pia.226

L'Heritier, M., Baron, S., Cassayre, L. and Tereygeol, F. 2015 'Bismuth behaviour during ancient processes of silver-lead production', Journal of Archaeological Science 57, 56-68. https://doi.org/10.1016/j.jas.2015.02.002

McConnell, J.R., Wilson, A.I., Stohl, A., Arienzo, M.M., Chellman, N.J., Eckhardt, S., Thompson, E.M., Pollard, A.M. and Steffensen, J.P. 2018 'Lead pollution recorded in Greenland ice indicates European emissions tracked plagues, wars, and imperial expansion during antiquity', Proceedings of the National Academy of Sciences 115, 5726-31. https://doi.org/10.1073/pnas.1721818115

McKerrell, H. and Stevenson, R.B.K. 1972 'Some analyses of Anglo-Saxon and associated Oriental silver coinage' in E.T. Hall and D.M. Metcalf (eds) Methods of Chemical and Metallurgical Investigation of Ancient Coinage, London: Royal Numismatic Society. $195-209$.

Meyers, P. 2003 'Production, distribution, and control of silver: information provided by elemental composition of ancient silver objects' in L. van Zelst (ed) Patterns and Process: A Festschrift in Honor of Dr Edward V. Sayre, Washington, DC. 271-88. 
Mishara, J. and Meyers, P. 1974 'Ancient Egyptian silver: a review' in A. Bishay (ed) Recent Advances in Science and Technology of Materials, Proceedings of the Cairo Solid State Conference III, New York: Plenum Press. 29-45. https://doi.org/10.1007/978-1-4684$\underline{7233-23}$

Moorey, P.R.S. 1994 Ancient Mesopotamian Materials and Industries: The Archaeological Evidence, Oxford: Clarendon.

Montero-Ruiz, I., Geber, M, Hunt, M., Renzi, M. and Rovira, S. 2008 'Caracterización analítica de la producción metalúrgica protohistórica de plata en Cataluña', Revista d'Arqueologia de Ponent 18, 292-316.

Moureau, S. and Thomas, N. 2016 'Understanding texts with the help of experimentation: the example of cupellation in Arabic scientific literature', Ambix 63, 98-117. https://doi.org/10.1080/00026980.2016.1216691

Muller, O. and Gentner W. 1979 'On the composition and silver sources of Aeginetan coins from the Asyut Hoard', Archaeo-Physika 10 , Proceedings of the 18th international symposium on archaeometry and archaeological prospection, Bonn, 14-17 March 1978,

Rheinisches Landesmuseum Bonn. 176-93.

Murillo-Barroso, M., Montero-Ruiz, I., Rafel, N., Hunt-Ortiz, M.A. and Armada, X-L. 2016 'The macro-regional scale of silver production in Iberia during the first millennium BCE in the context of Mediterranean contacts', Oxford Journal of Archaeology 35, 75-

100. https://doi.org/10.1111/ojoa.12079

Mussche, H.F. 1974 Thorikos: A guide to the excavation, Bruxelles: Comité des fouilles belges en

Grèce. https://doi.org/10.3406/antiq.2006.2607

Mussche, H.F. 1998 Thorikos. A mining town in ancient Attika, Ghent: Comité des fouilles belges en Grèce.

Mussche H.F. 2006 'More about the silver-rich lead of Ancient Laurion', L'antiquité Classique 75, 225-30.

Mylonas, G.E. 1973 Ho Taphikos Kyklos B ton Mykenonv, Athens.

Nezafati, N. and Pernicka, E. 2012 'Early silver production in Iran', Iranian Archaeology 3, 37-45.

Özgüç, T. and Özgüç, N. 1953 Türk Tarih Kurumu tarafından yapılan Kültepe kazısı raporu, 1949, Ankara: Türk Tarih Kurumu yayınlarından $\mathrm{V} / 12$. 
OXALID 2020 Oxford Archaeological Lead Isotope Database http://oxalid.arch.ox.ac.uk/ [Last accessed: 2 March 2020].

Papadopoulos, S. 2008 'Silver and copper production practices in the prehistoric settlement at Limenaria, Thasos' in I. Tzachili (ed) Aegean Metallurgy in the Bronze Age, Proceedings of an International Symposium Held at the University of Crete, Rethymnon, Greece, on November 19-21, 2004, Athens. 59-67.

Patterson, C.C. 1971 'Native copper, silver, and gold accessible to early metallurgists', American Antiquity 36, 286-

321. https://doi.org/10.2307/277716

Pernicka, E. 1981 'Archaometallurgische untersuchungen zur antiken silbergewinnung in Laurion: I. Chemishe Analyse griechischer BleiSilber-Erze", Erzmetall 34, 396-400.

Pernicka, E. and Bachmann, H.G. 1983 'Archäometallurgische Untersuchungen zur antiken Silbergewinnung in Laurion: III. Das Verhalten einiger Spurenelemente beim Abtreiben des Bleis', Erzmetall 36, 592-97.

Pernicka, E. and Wagner, G.A. 1985 'Die metallurgische Bedeutung von Sifnos im Altertum' in G.A. Wagner, G. Weisgerber and W. Kroker (eds) Silber, Blei und Gold auf Sifnos : prähistorische und antike Metallproduktion, Bochum. 200-11.

Pernicka, E., Gentner, W., Wagner, G.A., Vavelidis, M. and Gale, N.H. 1981 'Ancient lead and silver production on Thasos (Greece)', Revue d'Archéométrie, Supplement 1981, Actes du XXe symposium international d'archéométrie Paris 26-29 mars 1980 Volume III. 227-37. https://doi.org/10.3406/arsci.1981.1151

Pernicka, E., Wagner, G.A., Assimenos, K., Doumas, C., Begemann, F. and Todt, W. 1983 'An analytical study of prehistoric lead and silver objects from the Aegean' in A. Aspinall and S. E. Warren (eds) Proceedings of the 22nd Symposium on Archaeometry, Bradford. 292-302.

Pernicka E., Rehren, T. and Schmitt-Strecker, S. 1998 'Late Uruk silver production by cupellation at Habuba Kabira, Syria' in T. Rehren, A. Hauptmann and J.D. Muhly (eds) Metallurgica Antiqua: In honour of Hans-Gert Bachmann and Robert Maddin, Bochum. $123-34$.

Perreault, C. 2019 The Quality of the Archaeological Record, Chicago. https://doi.org/10.7208/chicago/9780226631011.001.0001 
Plenderleith, H.J. 1934 'Metals and metal technique' in C.L. Woolley (ed) Ur Excavations II: The Royal cemetery. A report on the Predynastic and Sargonid graves excavated between 1926 and 1931, London/Philadelphia: British Museum/Museum of the University of Pennsylvania, 284-98. http://www.etana.org/sites/default/files/coretexts/20263.pdf [Last accessed: 11 March 2020].

Prag, K. 1978 'Silver in the Levant in the fourth millennium BC' in P.R.S. Moorey, and P. Parr (eds) Archaeology in the Levant. Essays for Kathleen Kenyon, Warminster. 36-45.

Predel, B., Hoch, M. and Pool, M.J. 2004 Phase Diagrams and Heterogeneous Equilibria: A Practical Introduction, Berlin. 2526. https://doi.org/10.1007/978-3-662-09276-7

Reedy, C. and Reedy, T. 1988 'Lead isotope analysis for provenance studies in the Aegean region: a re-evaluation', MRS Proceedings 123, 65-70. https://doi.org/10.1557/PROC-123-65

Rehren T. and Prange M. 1998 'Lead metal and patina: a comparison' in T. Rehren, A. Hauptmann and J.D. Muhly (eds) Metallurgica Antiqua: In honour of Hans-Gert Bachmann and Robert Maddin, Der Anschnitt 8, Bochum: Deutsches Bergbau-Museum. 183-96.

Rehren, T., Vanhove, D., Mussche, H. and Oikonomakou, M. 1999 'Litharge from Laurion: a medical and metallurgical commodity from South Attika', L'Antiquité Classique T.68, 299-308. https://doi.org/10.3406/antiq.1999.1348

Rehren, T., Vanhove, D. and Mussche, H. 2002 'Ores from the ore washeries in the Lavriotiki', Metalla (Bochum) 9(1), 27-46.

Renfrew, C. 1967 'Cycladic metallurgy and the Aegean Bronze Age', American Journal of Archaeology 71, 1-

20. https://doi.org/10.2307/501585

Rickard, T.A. 1928 'The mining of the Romans in Spain', The Journal of Roman Studies 18, 129-43. https://doi.org/10.2307/296070

Salkield, L.U. 1982 'The Roman and Pre-Roman slags at Rio Tinto Spain' in T.A. Wertime and S.F. Wertime (eds) Early Pyrotechnology: The evolution of the first fire-using industries, Washington DC, 137-47.

Salkield, L.U. 1987 A Technical History of the Rio Tinto Mines: some notes on exploitation from pre-Phoenician times to the 1950s, London: The Institute of Mining and Metallurgy. https://doi.org/10.1007/978-94-009-3377-4

Scott, D.A. 2010 Ancient Metals: Microstructure and Metallurgy: Vol. 1, Los Angeles: Conservation Science Press. 
Servais, J. 1967 'Les fouilles sur le haut du Vélatouri' in H.F. Mussche, J. Bingen, J. Servais, J. De Geyter, T. Hackens, P. Spitaels and A. Gautier (eds) Thorikos III 1965, Brussels. 24-7.

Sherratt, S. 2000 Catalogue of Cycladic Antiquities in the Ashmolean Museum: The captive spirit I, Oxford.

Shepherd, R. 1993 Ancient Mining, London and New York: Elsevier Applied Science.

Sisco, A.G. and Smith, C.S. 1951 Erker's Treatise on Ores and Assaying, Chicago.

Skarpelis, N. 2002 'Geodynamics and evolution of the miocene mineralization in the Cycladic-Pelagonian belt, Hellenides', Bulletin Geological Society of Greece 34, 2191-206. https://doi.org/10.12681/bgsg.16862

Smith, C.S. 1967 'The interpretation of microstructures of metallic artefacts' in W. Young (ed) Application of Science in the Examination of Works of Art, Boston. 69-111.

Spitaels, P. 1984 'The Early Helladic period in Mine no. 3 (theatre sector)' in H.F. Mussche, , J. Bingen, J. Servais and P. Spitaels (eds) Thorikos VIII 1972-1976, Ghent. 151-74.

Stos-Gale, Z.A. 2014 'Silver vessels in the Mycenaean Shaft Graves and their origin in the context of the metal supply in the Bronze Age Aegean' in H.H. Meller, R. Risch and E. Pernicka (eds) Metals of Power - Early gold and silver, Landesamt für Denkmalpflege und Archäologie Sachsen-Anhalt and Landesmuseum für Vorgeschichte Halle (Saale). 183-208.

Stos-Gale, Z.A. and Gale, N.H. 1982 'The sources of Mycenaean silver and lead', Journal of Field Archaeology 9, 46785. https://doi.org/10.1179/009346982791504490

Stos-Gale, Z.A. and Macdonald, C.F. 1991 'Sources of metals and trade in the Bronze Age Aegean' in N.H Gale (ed) Bronze Age Trade in the Mediterranean: papers presented at the Conference held at Rewley House, Oxford, in December 1989, Uppsala: Åström. 249-88.

Stos-Gale, Z.A., Gale, N.H., Houghton, J. and Speakman, R. 1995 'Lead isotope data from the Isotrace Laboratory, Oxford: archaeometry data base 1, ores from the Western Mediterranean', Archaeometry 37, 407-15. https://doi.org/10.1111/j.14754754.1995.tb00753.x

Strong, D.E. 1966 Greek and Roman Gold and Silver Plate, London: Methuen. 
Tartaron, T. 2013 Maritime Networks in the Mycenaean World, Cambridge. https://doi.org/10.1017/CBO9781139017374

Treister, M.Y. 1996 The Role of Metals in Ancient Greek History, Leiden: Brill. https://doi.org/10.1163/9789004329829

Tylecote, R.F. 1987 The Early History of Metallurgy in Europe, London: Longman.

Vavelidis, M., Bassiakos, I., Begemann, F., Patriarcheas, K., Pernicka, E., Schmitt-Strecker, S. and Wagner, G.A. 1985 'Geologie und Erzvorkommen' in G.A. Wagner, G. Weisgerber and W. Kroker (eds) Silber, Blei und Gold auf Sifnos : prähistorische und antike

Metallproduktion, Bochum. 59-80.

Voudouris, P. 2005 'Gold and silver mineralogy of the Lavrion deposit, Attika, Greece' in J. Mao and F.P. Bierlein (eds) Mineral Deposit Research: Meeting the global challenge, Berlin. 1089-92. https://doi.org/10.1007/3-540-27946-6 278

Voudouris, P. and Economou-Eliopoulos, M. 2003 'Mineralogy and chemistry of Cu-rich ores from the Kamariza carbonate-hosted deposit (Lavrion), Greece' in D. Eliopoulos (ed) Mineral Exploration and Sustainable Development, Rotterdam. 1039-42.

Voudouris, P., Melfos, V., Spry, P.G., Bonsall, T. A., Tarkian, M. and Solomos, C. 2008 'Carbonate-replacement Pb-Zn-Ag \pm Au mineralization in the Kamariza area, Lavrion, Greece: Mineralogy and thermochemical conditions of formation', Mineralogy and Petrology 94, 85-106. https://doi.org/10.1007/s00710-008-0007-4

Wagner, G.A. and Weisgerber, G. 1985 'Silver lead and gold on Siphnos - prehistoric and antique metal production' in G.A. Wagner, G. Weisgerber and W. Kroker (eds) Silber, Blei und Gold auf Sifnos : prähistorische und antike Metallproduktion, Bochum. $229-32$.

Wagner, G.A., Gentner, W., Gropengiessner, H. and Gale, N.H. 1980 'Early Bronze Age lead-silver mining and metallurgy in the Aegean: the ancient workings on Siphnos' in P.T. Craddock (ed) Scientific Studies in Early Mining and Extractive Metallurgy, London. 143-72.

Wanhill, R.J.H. 2003 'Ancient silver embrittlement: significances of copper, lead and cold-deformation', National Aerospace Laboratory NLR, NLR-TP-2003-617.

Wanhill, R.J.H., Steijaert, J.P.H.M., Leenheer, R. and Koens, J.F.W. 1998 'Damage assessment and preservation of an Egyptian silver vase (300-200 BC)', Archaeometry 40, 123-37. https://doi.org/10.1111/j.1475-4754.1998.tb00828.x 
Weeks, L. 2013 'Iranian metallurgy of the fourth millennium BC in its wider technological and cultural contexts' in C.A. Petrie (ed) Ancient Iran and its Neighbours: Local developments and long-range interactions in the fourth-millennium BC. Oxford: British Institute of Persian Studies/Oxbow Books. 277-91. https://doi.org/10.2307/j.ctvh1dn46.19

Weisgerber, G. and Heindich, G. 1983 'Laurion - und kein Ende? Kritische Bemerkungen zum Forschungsstand über eines der bedeutendsten antiken Bergreviere', Der Anschnitt 35, 190-200.

Weisgerber, G. and Pernicka, E. 1995 'Ore mining in prehistoric Europe: an overview' in G. Morteani and J.P. Northover (eds) Prehistoric Gold in Europe. Dordrecht. 159-82. https://doi.org/10.1007/978-94-015-1292-3 12

Wertime, T.A. 1968 'A metallurgical expedition through the Persian desert', Science 159, 92735. https://doi.org/10.1126/science.159.3818.927

Wertime, T.A. 1973 'The beginnings of metallurgy: a new look', Science 182, 875-87. https://doi.org/10.1126/science.182.4115.875

Wood, J.R. 2019 The transmission of silver and silver extraction technology across the Mediterranean in Late Prehistory: An archaeological science approach to investigating the westward expansion of the Phoenicians, Unpublished PhD thesis, University College London (UCL). https://discovery.ucl.ac.uk/id/eprint/10070018/

Wood, J.R. and Montero-Ruiz I. 2019 'Semi-refined silver for the silversmiths of the Iron Age Mediterranean: a mechanism for the elusiveness of Iberian silver', Trabajos de Prehistoria 76, 272-85. https://doi.org/10.3989/tp.2019.12237

Wood, J.R. and Hsu, Y-T. 2019 'An archaeometallurgical explanation for the disappearance of Egyptian and Near Eastern Cobalt-Blue glass at the end of the Late Bronze Age', Internet Archaeology 52. https://doi.org/10.11141/ia.52.3

Wood, J.R., Charlton, M.J., Murillo-Barroso, M. and Martinón-Torres, M. 2017a 'Gold parting, iridium and provenance of ancient silver: a reply to Pernicka', Journal of Archaeological Science 86, 127-30. https://doi.org/10.1016/j.jas.2017.07.005

Wood, J.R., Charlton, M.J., Murillo-Barroso, M. and Martinón-Torres, M. 2017b 'Iridium to provenance ancient silver', Journal of Archaeological Science 81, 1-12. https://doi.org/10.1016/i.jas.2017.03.002

Wood, J.R., Montero-Ruiz, I. and Martinón-Torres, M. 2019 'From Iberia to the Southern Levant: the movement of silver across the Mediterranean in the Early Iron Age', Journal of World Prehistory 32, 1-31. https://doi.org/10.1007/s10963-018-09128-3 
Wood, J.R., Montero-Ruiz, I. and Bell, C. 2020 'The origin of the Tel Dor hacksilver and the westward expansion of the Phoenicians in the Early iron Age', Journal of Eastern Mediterranean Archaeology and Heritage Studies 8, 1-

21. https://doi.org/10.5325/jeasmedarcherstu.8.1.0001

Yahalom-Mack, N., Langgut, D., Dvir, O., Tirosh, O., Eliyahu-Behar, A., Erel, Y., Langford, B., Frumkin, A., Ullman, M. and Davidovich, O. 2015 'The earliest lead object in the Levant', PLOS ONE 10, e0142948. https://doi.org/10.1371/journal.pone.0142948

Yener, K.A., Sayre, E.V., Joel, E.C., Özbal, H., Barnes, I.L. and Brill, R.H. 1991 'Stable lead isotope studies of Central Taurus ore sources and related artifacts from Eastern Mediterranean Chalcolithic and Bronze Age sites', Journal of Archaeological Science 18, 54177. https://doi.org/10.1016/0305-4403(91)90053-R

Zaccagnini, C. 1983 'Patterns of mobility among ancient Near Eastern craftsmen', Journal of Near Eastern Studies 42, 24564. https://doi.org/10.1086/373031

Zhou, J. 2010 'Process mineralogy of silver ores and applications in flowsheet design and plant optimization' in D. Fragomeni (ed) Proceedings 2010, 42nd Annual Meeting of the Canadian Mineral Processors: held at the Westin Hotel, Ottawa, Ontario, Canada, 19th, 20th and 21st January 2010; 2010 Proceedings, Ottawa. 143-61. 